\title{
COMPARATIVE ANALYSIS OF NET ENERGY BALANCE OF SATELLITE POWER SYSTEMS (SPS) AND OTHER ENERGY SYSTEMS
}

April 1980

U.S. Department of Energy

Office of Energy Research

Satellite Power System Project Division

\section{DOE/NASA}

SATELLITE POWER SYSTEM

Concept Development and

Evaluation Program 


\section{DISCLAIMER}

This report was prepared as an account of work sponsored by an agency of the United States Government. Neither the United States Government nor any agency Thereof, nor any of their employees, makes any warranty, express or implied, or assumes any legal liability or responsibility for the accuracy, completeness, or usefulness of any information, apparatus, product, or process disclosed, or represents that its use would not infringe privately owned rights. Reference herein to any specific commercial product, process, or service by trade name, trademark, manufacturer, or otherwise does not necessarily constitute or imply its endorsement, recommendation, or favoring by the United States Government or any agency thereof. The views and opinions of authors expressed herein do not necessarily state or reflect those of the United States Government or any agency thereof. 


\section{DISCLAIMER}

Portions of this document may be illegible in electronic image products. Images are produced from the best available original document. 
Avallable from:

National Technical Information Service (NTIS)

U.S. Department of Commerce

5285 Port Royal Road

Springfield, Virginia 22161

Price: Printed copy: $\$ 7.25$

Microfiche: $\quad \$ 4.00$ 


\section{COMPARATIVE ANALYSIS OF NET ENERGY BALANCE OF SATELLITE POWER SYSTEMS (SPS) AND OTHER ENERGY SYSTEMS}

April 1980

Prepared by:

R. R. Cirillo, B. S. Cho, M. R. Monarch, and E. P. Levine

Integrated Assessments and Policy Evaluations Group

Energy and Environmental Systems Division

Argonne National Laboratory

Argonne, Illinois 60439

Under Contract No. 31-109-ENG-38

Prepared for:

U.S. Department of Energy

Office of Energy Research

Satellite Power System Project Division

Washington, D.C. 20545

\section{DOE/NASA}

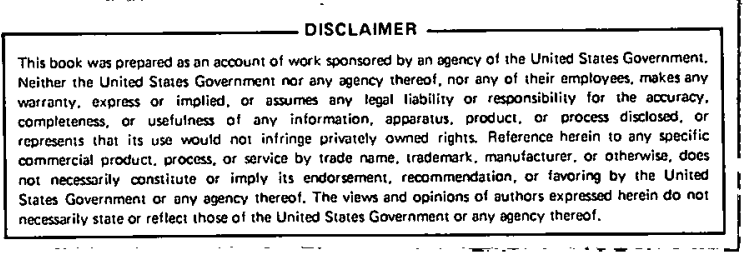

SATELLITE POWER SYSTEM

Concept Development

and

Evaluation Program 


\section{PAGES ii to iii WERE INTENTIONALLY LEFT BLANK}




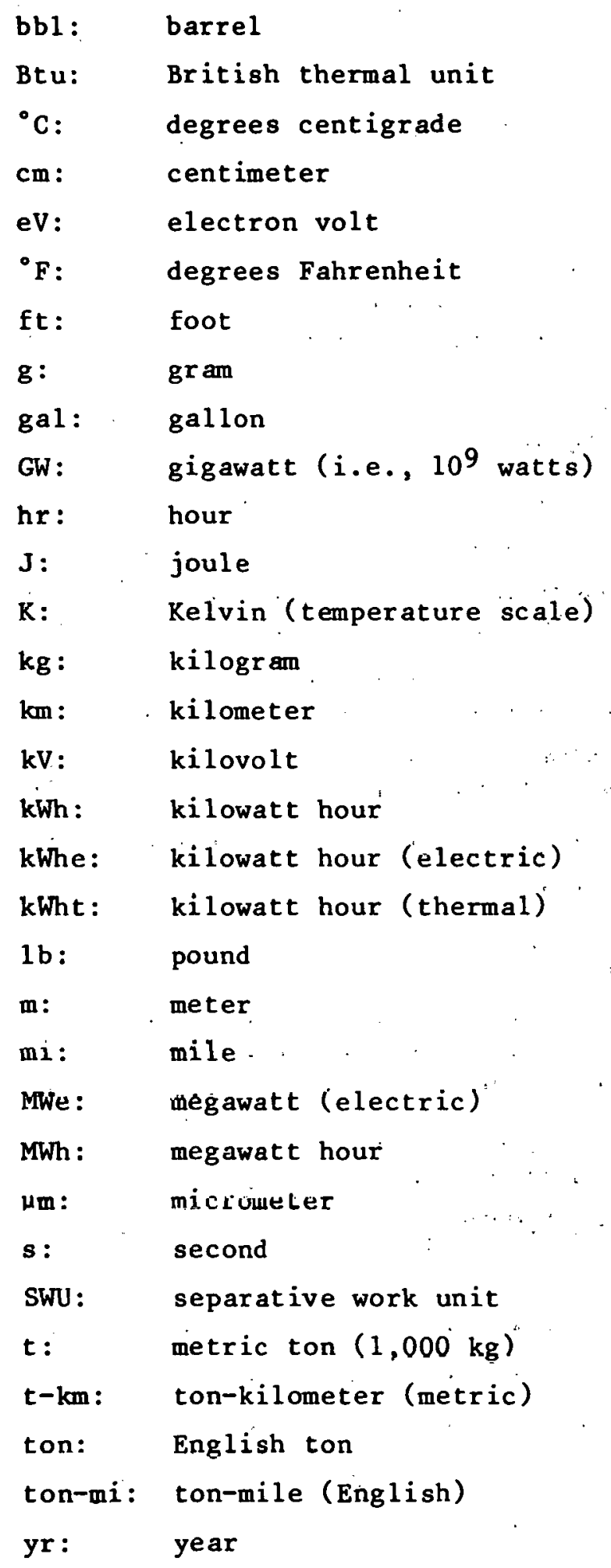


ABSTRACT. . . . . . . . . . . . . . . . . . . . . . . 1

1 EXECUTIVE SUMMARY. . . . . . . . . . . . . . . . . . . . . 1

2 SCOPE AND METHODOLOGY. . . . . . . . . . . . . . . . . . . . . 5

2.1 INTRODUCTION. . . . . . . . . . . . . . . . . . . 5

2.2 METHODOLOGICAL ALTERNATIVES . . . . . . . . . . . . . . . . 6

2.3 APPROACH. . . . . . . . . . . . . . . . . . . . . 7

2.3.1 Methodology. .................... 7

2.3.2 Resolution of Technical Issues . . . . . . . . . 8

2.3.3 Resolution of Philosophical Issues . . . . . . . . . 10

3 ALternative ENERG SYSTEMS . . . . . . . . . . . . . . . . . . . 13

3.1 COAL-BASED SYSTEMS. . . . . . . . . . . . . . . . . . . 13

3.1.1. Atmospheric Fluidized Bed Combustion........... 13

3.1.2 Coal Gasification/Combined Cycle . . . . . . . . . . 13

3.2 NUCLEAR SYSTEM. . . . . . . . . . . . . . . . . . 16

3.3 TERRESTRIAL SOLAR ENERGY SYSTEMS. . . . . . . . . . . . . . . . 16

3.3.1 Terrestrial Solar Thermal System . . . . . . . . . . . 16

3.3.2 Terrestrial Solar Photovoltaic System. . . . . . . . . . . 18

3.4 SATELLITE POWER SYSTEM. . . . . . . . . . . . . . . . . . . 18

4 RESUlTS OF ANALYSIS. . . . . . . . . . . . . . . . . . . . . . . . 23

4.1 BASELINE CASE . . . . . . . . . . . . . . . . . . . 23

4.2 EFFECT OF IINGERTAIN DATA. . . . . . . . . . . . . . . . . . . 27

4.2.1 Energy Intensity of Silicon Cell Production. . . . . . . 27

4.2.2 Cell Lifetime. . . . . . . . . . . . . . . . . . . 29

4.2.3 Energy Supply for Silicon Production . . . . . . . . . 29

4.2.4 Quantity of Silicon Required . . . . . . . . . . . . 30

4.2.3 Eutigy Intensity nf GaAlAs Cell Production . . . . . . . . 30

4.2.6 Other Material Energy Requirements . . . . . . . . . . . 31

4.3 EFFECT OF ALTERNATIVE METHOdS: OTHER STUdiES . . . . . . . . . . 31

5 CONCLUSIONS AND RECOMMENDATIONS. . . . . . . . . . . . . . . . 35

REFERENCES. . . . . . . . . . . . . . . . . . . . . . . 37

APPENDIX A - DETAILS OF THE METHODOIOGY . . . . . . . . . . . . . . . . . 39

APPENDIX B - COAL FUEL CYCLE SYSTEMS. . . . . . . . . . . . . . . 55

APPENDIX C - NUCLEAR FUEL CYCLE . . . . . . . . . . . . . . . . 75

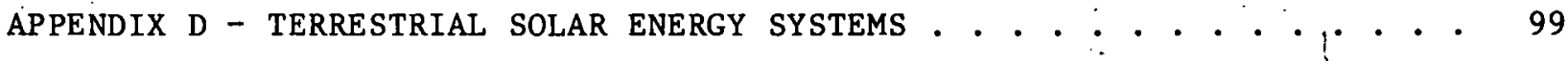

APPENDIX E - SATELLITE POWER SYSTEM . . . . . . . . . . . . . . . 121 
THIS PAGE

WAS INTENTIONALLY LEFT BLANK 


\section{LIST OF FIGURES}

No.

1.1 Comparison of System Energy Payback Periods... . . . . . . . . . . . 4

2.1 Schematic of Energy Balance. . . . . . . . . . . . . . . . 7

4.1 Variation of Net Energy Parameters with Silicon Energy Requirements. 28

A.1 Schematic Chart of System Element Energy Balance . . . . . . . . . . 42

A.2 Potential for Reduction in Silicon Energy Requirements . . . . . . . 50

B.1 Simplified Flow Diagram of an AFBC Cycle . . . . . . . . . . . . 58

B.2 Primary Energy Flow Diagram of an AFBC Cycle . . . . . . . . . . 63

B.3 Simplified Flow Diagram of an AFBC Cycle . . . . . . . . . . . . 67

B.4 Primary Energy Flow Diagram of Low-Btu CG/CC System. . . . . . . . . 70

C.l Simplified Flow Diagram of the Nuclear Fuel Cycle. . . . . . . . . 77

C.2 Energy Flow Pathway of the Nuclear Fuel Cycle. . . . . . . . . . . . 94

D.1 Power Conditioning Module Functional Block Diagram . . . . . . . . 102

D.2 Energy Flow of 1000-MWe Solar Photovoltaic Plant in Barstow, CA. . . 107

D.3 Schematic Diagram of Solar Thermal Plant . . . . . . . . . . . . 111

D.4 Energy Flow of 100-MWe Solar Thermal Plant in Barstow, CA. . . . . 115

E.1 Simplified Flow Diagram and Efficiency Chain of SPS. . . . . . . . . 124

E.2 Primary Energy Flow Diagram for SPS. . . . . . . . . . . . . 131

\section{LIST OF' 'IAB̈LES}

1.1 Summary of Energy Balance Data . . . . . . . . . . . . . . . 2

3.1 Summary of AFBC Energy Paramaters. . . . . . . . . . . . . . . 14

3.2 Summary of Coal Gasification/Combined Cycle Energy Parameters. . . . 15

3.3 Summary of LWR Energy Parameters . . . . . . . . . . . . . . . 17

3.4 Summary of Terrestrial Solar Thermal Energy Parameters . . . . . . 19

3.5 Summary of Terrestrial Solar Photovoltaic Energy Parameters. . . . . 20

3.6 Summary of SPS Energy Paramters. . . . . . . . . . . . . . . . 22

4.1 Summary of Energy System Inputs and Outputs. . . . . . . . . . . . . 24

4.2 Summary of Energy Balance Data . . . . . . . . . . . . . . . 25

4.3 Differences in Silicon Requirements. . . . . . . . . . . . . . 30

4.4 Effect of Energy Intensity Assumptions on SPS Energy Balance . . . . 31

A.1 Fuel Heating Values. . . . . . . . . . . . . . . . . . 43

A.2 Adjustments to Energy Intensity for Input/Output Analysis. . . . . 47

A.3 Energy Costs of Delivered Fuel . . . . . . . . . . . . . . 47 
A.4 Material Energy Intensities. . . . . . . . . . . . . . . . . . 49

B.1 Energy Balance Parameters for AFBC System. . . . . . . . . . . . . . 64

B.2 Energy Efficiencies for the Primary Energy Flow in the AFBC System . 65

B.3 Energy Balance for CG/CC System. . . . . . . . . . . . . . . 71

B.4 Energy Efficiencies for the Primary Energy Flow in the CG/CC System. 72

C.1 Uranium Mining - Direct Energy Requirements. . . . . . . . . . . 78

C.2 Uranium Mining - Total Energy Requiromento . . . . . . . . . . 79

C.3 Uranium Milling - Direct Energy Requirements . . . . . . . . . . . 80

C.4 Uranium Milling - Total Energy Requirements. . . . . . . . . . . . . 81

C.5 Energy Requirements of Uranium Purification. . . . . . . . . . . . . 82

C.6 Enrichment Energy Requirements . . . . . . . . . . . . . . . . 83

C.7 Energy Requirements for LWR Fuel Fabrication . . . . . . . . . . . 85

C.8 Major Material Requirements for a 1000-MWe LWR . . . . . . . . . . 86

C.9 Major Categories for Plant Groupings Shown in Table C.8. . . . . . . 87

C.10 Major Material Requirements for a 1000-MWe LWR . . . . . . . . . . . 87

C.11 Anllual Energy Requirements for a 1000-MWe LWR. . . . . . . . . . . . 88

C.12 Annual Fuel Storage Requirements . . . . . . . . . . . . . 89

C.13 Waste Storage Annual Requirements. . . . . . . . . . . . . . 90

C.14 Trausportation Energy Requirements: Ore Mill to Enrichment Plant. . 92

C..15 Tranoportation Energy Requirements: Enrichment to Storage or Reprocessing of Waste. . . . . . . . . . . . . . . . . 92

C.16 Energy Balance Parameters for Nuclear LWR Bystem . . . . . . . . . 95

D.1 Energy Balance Parameters for Terrestrial solar Photovollaic system. 106

D.2 Solar Cell Efficiencies. . . . . . . . . . . . . . . 109

D.3 Energy Balance Parameters for Terrestrial Solar Thermal Syotem . . 116

E.1 Material Requirements for SPS. . . . . . . . . . . . . . . 128

E.2 Masses of SPS Subsystems . . . . . . . . . . . . . . . . . 129

E.3 Energy Balance Parameters for SPS. . . . . . . . . . . . . . 132

E.4 Total Masses of All SPS Program Components . . . . . . . . . . . 133

E.5 Total Capital Inputs for SPS . . . . . . . . . . . . . . . . . 134 


\title{
COMPARATIVE ANALYSIS OF NET ENERGY BALANCE \\ FOR SATELLITE POWER SYSTEMS AND \\ OTHER ENERGY SYSTEMS
}

\author{
ABSTRACT
}

\begin{abstract}
This report assesses the net energy balance of seven electric energy systems: two coal-based, one nuclear, two terrestrial solar, and two solar power satellites, with principal emphasis on the latter two systems. Solar energy systems require much less operating energy per unit of electrical output. However; on the basis of the analysis used here, coal and nuclear systems are two to five times more efficient at extracting useful energy from the primary resource base than are the solar energy systems. The payback period for all systems is less than 1.5 years, except for the terrestrial photovoltaic $(19.8 \mathrm{yr})$ and the solar power satellite system $(6.4 \mathrm{yr})$, both of which rely on energy-intensive silicon cells.
\end{abstract}

\section{EXECUTIVE SUMMARY}

A preliminary assessment of the net energy balance of seven electric energy systems was conducted, using existing data and methods, to identify differences and to recommend further work needed to improve the evaluation. Two of the systems are coal-based--a 747-MWe atmospheric fluidized bed combustion (AFBC) and a 741.5-MWe coal-gasification/combined-cycle (CG/CC) system; one is nuclear--a 1000-MWe light water reactor (LWR); two are terrestrial solar--a 100-MWe thermal and a 1000-MWe photovoltaic system; and two are satellite power systems--5000-MWe satellites using, respectively, silicon cells and gallium aluminum arsenide (GaAlAs) cells. The principal emphasis is on the satellite power system (SPS).

A combination of process analysis and input/output analysis was used to compute, for each system, the energy balance parameters: gross efficiency, operating efficiency, operating ratio, lifetime efficiency, lifetime ratio, and payback period. These parameters are defined in Table 1.1, which summarizce the basic results.

The coal and nuclear systems are two to five times more efficient than the solar energy systems, but use nonrenewable resources, which is undesirable when concern for resource depletion is important. The conversion efficiency of the system dominates the result: the calculation of efficiency is not 
Table 1.1. Summary of Energy Balance Data

\begin{tabular}{|c|c|c|c|c|c|c|c|}
\hline \multirow[b]{2}{*}{ Parameter } & \multicolumn{2}{|c|}{ Coal } & \multirow{2}{*}{$\begin{array}{c}\frac{\text { Nuclear }}{\text { LWR }} \\
\text { tw }\end{array}$} & \multicolumn{2}{|c|}{ Terrestrial Solar ${ }^{2}$} & \multicolumn{2}{|c|}{ SPS $^{a}$} \\
\hline & $\dot{A F B C}$ & $\mathrm{CG} / \mathrm{CC}$ & & Thermal & $\begin{array}{l}\text { Photo- } \\
\text { voltaic }\end{array}$ & Silicon & GaAlAs \\
\hline Gross Effic:ency, :c & 28.1 & 36.7 & 21.7 & 11.4 & 5.7 & 7.0 & 6.9 \\
\hline Operating E Eficiency, \%d & 26.7 & 33.4 & 20.4 & 11.4 & 5.7 & 7.0 & 6.9 \\
\hline Operating Ratioe & 5.33 & 3.67 & 3.32 & 26.74 & 27.34 & 16.67 & 77.89 \\
\hline Lifetime Efficiencs, \% f & 26.4 & 33.0 & 20.3 & 11.3 & 5.4 & 6.9 & 6.9 \\
\hline Lifetime Raciog & 4.43 & 3.26 & 3.04 & 11.54 & 1.43 & 3.85 & 17.97 \\
\hline $\begin{array}{l}\text { Payback Period } \\
\text { (Electric Basis), } 7 \mathrm{r}^{\mathrm{h}}\end{array}$ & 1.30 & 1.11 & 1.14 & 1.48 & $19 . \varepsilon 2$ & 6.38 & 1.30 \\
\hline
\end{tabular}

The data for the solar energy systems are limited and, in some cases, highly uncertain; conclusions shoulc be drawn with caution.

bSilicon sysiem.

${ }^{{ }^{C}}$ Gross Efficiency = Annual Net Output/Annial Primary Input.

dOperating Efficiency = Annual Net Output!Annual Primary + Operating + Internal Inputs.

Operating Ratio = snnual Net Output/Annual Operating + Internal Inputs.

$\mathrm{f}_{\text {Lifetime Efficienc }}=$ Lifetime Net Output/Lifetime Primary + Operating + Internal + Capital Inputs.

BLifetime Ratio = Lifetime Net Output/Liftetime Operating + Internal + Capital Inputs.

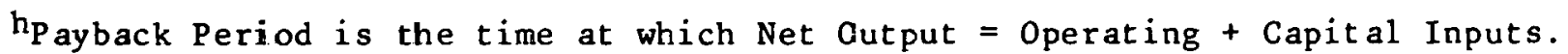


sensitive to gross, operating, or lifetime efficiency figures. Because efficiency parameters cannot take into account the fact that the solar energy systems operate from a renewable, effectively inexhaustible, resource. base, whereas nuclear and coal systems operate from a nonrenewable resource base, one must conclude that efficiency is not a good measure of comparability between the solar and the coal and nuclear systems.

Although the operating ratio results demonstrate that the solar energy systems require substantially less operating energy per unit of electrical output, the large capital investment reduces their lifetime ratios significantly. For silicon-cell satellite power systems (SPS/Si) and terrestrial photovoltaic systems, the lifetime ratios are less than that of the best coal system.

The payback period for all systems except SPS/Si and terrestrial photovoltaic is less than 1.5 years. For both these exceptions, the long payback results primarily from the energy intensity of silicon production. For the SPS/Si system, several possibilities -- e.g., decreased energy requirements for cell production, use of solar-generated rather than conventional electrical power in cell manufacture, increased cell 1 ifetime, and decreased silicon requirements -- could make the payback period comparable to that of the other systems. (The payback periods of the other systems could also be reduced slight.ly if solar electricity were substituted for conventional electricity in their manufacture.) In contrast, the best combluation of conditions for the terrestrial photovoltaic system still would result in a payback of about six years. Figure 1.1 summarizes the range of payback conditions.

The difference between the SPS/Si and the terrestrial photovoltaic system occurs because the SPS/Si system would operate $24 \mathrm{hr} /$ day, as compared to about 8-10 hr/day for the terrestrial system, and after the capital energy investment has been male in the silicnn cells, the SPS would use the material morc intensively and thus more efficiently.

The results of this study were compared to those from three earlier studies of the net energy balance of satellite power systems. Differences among the results arise primarily from different initial assumptions in the various sludies. When these assumptions are resolved to the same set of conditions, the resulting net energy balance parameters from the differint studies become romparable. 


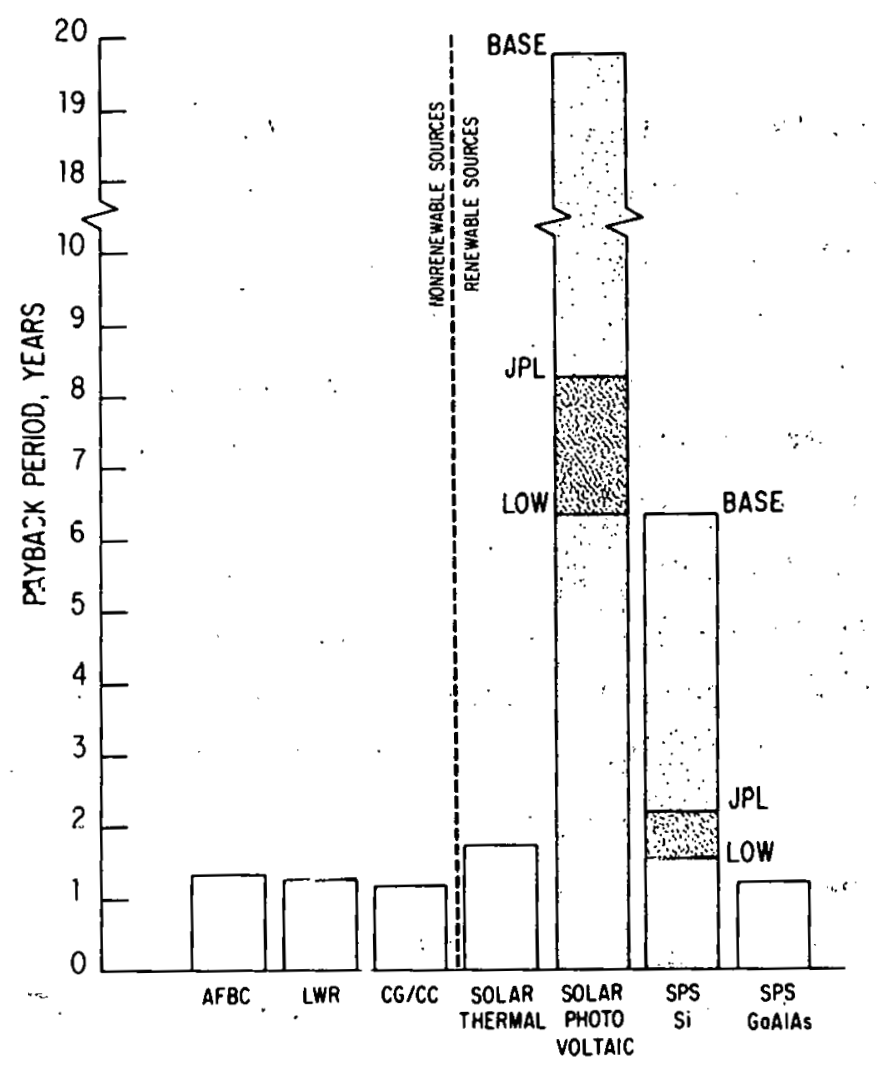

Fig. 1.1. Comparison of 3ystem Energy Payback. Periods

Recommendations for future activity include the following:

1. No further analysis is recommended for the coal, nuclear, and terrestrial solar thermal systems, because their payback periods are so similar; little can be gained by further comparisons of SPS with these systems.

2. More detailed assessment of energy requirements for production of silicon cells is needed, because the results for SPS/Si and terrestrial photovoltaic systems depend so heavily on this energy input. A study of the potential for reducing such energy consumption in recummended, and the net enurgy balance parameters for SPS/Si

3. The energy inputs required for production of GaAlAs cells need study, and the net energy balance parameters for SPS/GaAlAs should be recomputed with the resulting new information. The information avallable at present is extremely limited, and although it suggests a very short paypack period the level of uncertainty dictates that is should be examined more carefully: 


\section{SCOPE AND METHODOLOGY}

\subsection{INTRODUCTION}

Net energy analysis is a developing tool that is coming to be more widely used in energy research and decision making. Its goal is to estimate the quantity of energy that must be invested in an energy system to recover useful energy output. The concept of net energy analysis has not been important in decisions about conventional energy systems, because those systems traditionally have been considered to provide substantially more energy than was required to put them into operation. However, advanced technologies require more energy investment to recover each unit of usable energy, so the net energy yield becomes an important decision parameter. Net energy output is not the only variable on which decisions must be based; it must be considered in the light of economic, environmental, social, and other factors of interest, including use of renewable versus non-renewable resources and depletion of nonenergy mineral resources. All these factors are important in a comparative assessment, but they are beyond the scope of a net energy study. They are more appropriately addressed separately.

For satellite power systems (SPS), the issue of net energy analysis was raised by Herendeen, 1 who suggested that an SPS system might be close to the payback 1 imit, i.e., might not return sufficient usable energy compared to the energy investment required. Other studies 2,3 have come to somewhat different conclusions. The objective of the present study, part of an overall comparative assessment of SPS and other energy technologies, was to conduct a preliminary evaluation of the net energy output for SPS and other technologies to draw some preliminary conclusions about how SPS compares with other systems and to identify where deficiencies in information exist. Available data and current analytic methods were used to obtain first-order estimates of the net energy balance parameters for the various systems; there has been no great effort to make detailed refinements of the calculations. This preliminary screening process will lead to a determination of where additional effort might best be spent to resolve differences in data and approach and to fill the information gaps.

Net energy analysis was applied to seven electrical energy systems: atmospheric fluidized bed combustion (AFBC) and coal gasification/combined- 
cycle (CG/CC), both coal-based; light water reactors (LWR), two terrestrial solar energy systems (photovoltaic and thermal), and two satellite power systems, SPS/Si and SPS/GaAlAs, which use, respectively, silicon cells and gallium aluminum arsenide cells.

\subsection{METHODOLOGICAL ALTERNATIVES}

Basically, three methodologies can be used for net energy analysis. Reference 4 gives a concise review and critique of the alternatives.

Process analysis involves a detailed balance of energy flows into and out of a system. It is the most accurate and most involved methodology, and can be applied to situations where vast amounts of process-specific information are available.

Input/output analysis uses a procedure analogous to economic inputoutput analysis to determine the energy costs of any energy supply. It involves identifying the interactions among all sectors, of the economy required to produce energy and translating the flow of goods and services among sectors into energy equivalents.

Ecoenergetics involves the assignment of energy values to various portions of the natural environment that are affected by the energy system. The process can be compared to a cost/benefit analysis in an economic evaluation.

In addition to the choire of analysis, eoveral other decisiuns uust be made to conduct a net energy analysis. Reference 4 classifies these decisions as follows:

Terhnical Icouco

- Definition of system hnundaries.

- Assignment of weights and quality fartors to different forma nf energy.

- Measurement of net energy.

- Treatment of temporal variations.

\section{Philosophical Issues}

- Evaluation of return on investment and discount rate.

- Treatment of labor requirements.

- Evaluation of sociological and institutional factors.

- Evaluation of environmental impacts. 


\subsection{APPROACH}

\subsubsection{Methodology}

In this preliminary analysis, a combination of process analysis and input/output analysis, rather than the econenergetics approach, was used. These methodologies have been widely applied in other studies and therefore satisfy a primary guideline for this assessment, 1.e., to use existing research.

Each of the systems chosen for evaluation can be described as a collection of system elements. Each element represents a particular piece of hardware, processing step, energy conversion step, or transportation mode. The energy balance of each system element can be described as shown. in Fig. 2.1. The primary input is in the form of fuel (e.g., coal into a coal-processing plant) or energy (e.g., heat from a solar collector into a boiler). The ancillary operating inputs are those energy forms (fuel, electricity, or materials) required to keep the process operating (e.g., electricity to run pumps, gasoline for motor vehicles, or limestone for a combustor). The gross output is the energy or processed fuel that results from the system element. A portion of this may be used to meet internal energy requirements (e.g., electricity required at a power plant site to operate equipment). The balance is the net output that goes on to become the primary input of the next system element. The losses are the difference between the outputs and inputs.

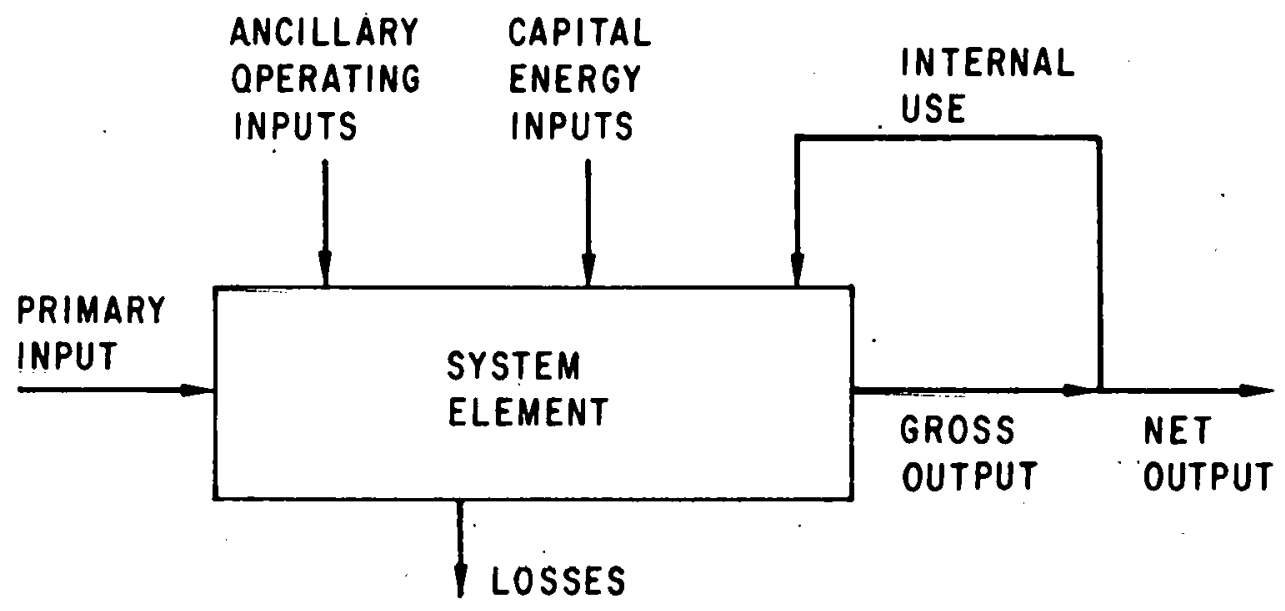

F1g. 2.1. Schematic of Energy Balance 
For each system element, data on the quantities of materials, fuels, and electricity required to build and operate the system were compiled. Published data on energy requirements, 1,3,5,6 expressed either in joules per ton of material or joules per dollar cost of material, were used to convert the physical material quantity or material cost into an energy equivalent. Where the material cost was available, this conversion was based on an input/ output table for each sector of the economy. For each type of material, an economic value of goods and services required from other sectors of the economy was computed, and an energy intensity figure was used to translate these econnmic coste into energy costs. In some cases, data already translated into energy equivalents in other net energy analyses were used. Because it was not deemed necessary at this time to perform a systematic check of the analytical processes used in these other studies, the potential exists for some inconsistencies among technologies in the calculation of indirect energy. These can be corrected in subsequent expansions of this work.

\subsubsection{Resolution of Technical Issues}

Several technical assumptions, discussed below, are implicit in the application of the analytical procedure.

System Boundaries. The boundary of each energy system was defined as extending from the primary rcsource (cual, uranium, or solar radiation) to electricity transmitted from the generating plant. The boundary includes environmental contrul systems and procedures to the extent that they are directly attributable to the energy system (e.g., cooling towers, particulate emission control, or strip mine reclamation). Materials, fuels, and electricity required for plant construction and operation enter the system from external sources, and the input/output analysis is the only method of dealing with their energy equivalents.

Energy Quality Factors. No attempt was made to attach a relative weight to the various forms of energy to account for the differences in quality and potential use. (For example, a joule-equivalent of a petroleum fuel is more useful than a joule-equivalent of coal). In the case of electricity required as ancillary operating input or as capital energy input, some adjustment must be made to reflect the basic resource cost of generating 
electricity. Nominally, 2.5 to 3 times as much basic energy in the form of coal, oil, gas, or uranium is required to generate a given amount of electricity at the generating plant. In the present situation, the input of a given amount of electricity into construction of another energy system requires basic resources four times the energy equivalent. Details of this conversion are given in Appendix A.

Measurement of Net Energy. Results of a net energy analysis may be tabulated in various ways, according to the parameters used in Eqs.2.1 to 2.5:

$$
\text { Gross Efficiency }=\text { NO/PI }
$$

where:

$$
\begin{aligned}
& \text { NO }=\text { Net output, and } \\
& \text { PI = Primary energy input (i.e., basic energy resources). }
\end{aligned}
$$

Gross efficiency is the basic measure of the amount of energy delivered per unit of input energy.

$$
\text { Operating Efficiency }=\mathrm{NO} /(\mathrm{PI}+\mathrm{AOI}+\mathrm{IU})_{?}
$$

where:

$$
\begin{aligned}
& \mathrm{AOI}=\text { Ancillary operating inputs, } \\
& \mathrm{IU}=\text { Internal use, and } \\
& \text { NO and } \mathrm{PI} \text { are as in Eq. } 2.1 .
\end{aligned}
$$

Operating efficiency is a more complete measure of how effectively the basic energy resource is being utilized, i.e., how efficient a given technology is at extracting useful energy from a primary energy form. This value is of more critical concern to an assessment of nonrenewable resourctes. (The numcrisal value of these efficiencies is always less than unity.)

$$
\text { Operating Ratio }=\mathrm{NO} /(\mathrm{AOI}+\mathrm{IU})
$$

where NO, AOI, and IU are as in Eq. 2.2. The operating ratio eliminates the energy content of the primary resource from calculation. This parameter is a measure of how much useful energy can be extracted from a primary resource. It considers the primary resource as fundamentally unusable in its basic state and measures the amount of energy that must be expended to convert it to a usable form. The higher the value of this ratio, the better the system is frou an energy balance standpoint; if the value is less than one, more energy is expended than is recovered. Although this is not the most desirable aituation, it may he acceptable when other factors are considered. 
Lifetime Efficiency $=\frac{T \times \text { NO }}{T(P I+A O I+I U)+C I}$

where:

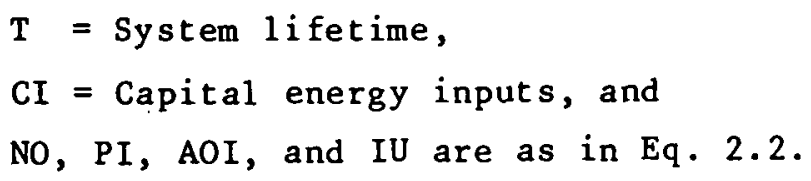

Lifetime Ratio $=\frac{T \times \text { NO }}{T(A O I+I U)+C I}$

Where the notation is as in Eq. 2.4. The lifetime efficiency and lifetime ratio are entirely analogous to the operating efficiency and operating ratio of Eqs. 2.2 and 2.3. They include in the balance the capital energy investment, which represents the energy required to construct the system.

Temporal Variations. This preliminary analysis did not consider the time variation of energy expenditures or energy returns in constructing and operating an energy system; all calculations were made on an annual basis with capital investments adjusted by the system lifetime. However, several of the energy systems examined have significant variations in the time rate of energy investment and usable energy output. A temporal analysis could treat the problems arising from high energy demands early in system deployment, but such an analysis was considered unnecessary for this preliminary study.

\subsubsection{Resolution of Philosophical Issues}

As with the technical issues, some philosophical assumptions are implied in the analysis; these are discussed below:

Return on Investment. No attempt was made to prescribc and evaluate a desirable rate of return on energy investment or a suitable discount rate for estimating present value. No estimates were made of the relative value of an early expenditure versus a later one. The only assessment of this type that was carried out was the straightforward calculation of thc payback period, i.e., the time required for the system to produce enough useful energy to match the energy invested in building and operating it. The payback period is that time at which the net output equals the capital energy input plus the cumulative ancillary operating inputs. 
Treatment of Labor. No attempt was made to place an energy equivalent on human labor because this issue is outside the realm in which net energy analysis can supply useful insight:-

Institutional/Sociological Considerations. No energy value can be placed on changes in institutional or social structures that are required or induced by an energy system. Institutional and social effects must be examined in other assessments of the technologies.

Environmental Impacts. The inclusion of direct requirements of energy for environmental control was discussed in defining system boundaries. No attempt was made to place energy values on such problems as ecosystem disturbance or withdrawal of 1 and from natural ecological uses, because these concerns are outside the realm of net energy analysis. 
THIS PAGE

\section{WAS INTENTIONALLY LEFT BLANK

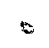




\section{ALTERNATIVE ENERGY SYSTEMS}

\subsection{COAL-BASED SYSTEMS}

Both atmospheric fluidized-bed combustion ( $A F B C$ ) and coal-gasification/ combined-cycle (CG/CC) generation are advanced technologies and are projected to be available for commercial use in about the same period as a satellite power system. Appendix B gives a detailed description of the configurations of these two coal-based systems selected for net energy evaluation.

\subsubsection{Atmospheric Fluidized Bed Combustion (AFBC)}

The system selected for analysis is a coal-fired AFBC steam generation system based on a design by the General Electric Company. A 747-MWe system was assumed, generating $4.25 \times 10^{9} \mathrm{kWhe} / \mathrm{yr}$ at a plant capacity factor of $65 \%$.

The total system analyzed includes stripmining of coal, coal preparation and transportation, handling of boțh coal and limestone, combustion in an AFBC furnace, and conversion to power in a conventional steam-cycle system including a steam turbine, generator, condenser, and cooling tower.

Table 3.1 summarizes the energy parameters for the system. The power plant itself requires most of the capital energy investment, accounting for $85 \%$ of the total capital energy. It also requires almost half the upelating energy investment. Other portions of the system are relatively small in the energy balance.

\subsubsection{Coal Gasification/Combined Cycle (CG/CC)}

The system studied is a gas-turbine/steam-turbine, combined-cycle unit, fired by the output of a low-Btu, fludized-bed coal gasifier. The design, based on a Westinghouse system, is for a 741.5-MWe station generating $4.22 \times 10^{9} \mathrm{kWhe} / \mathrm{yr}$ at a plant capacity factor of $65 \%$.

The overall system evaluated includes stripmining of coal, coal preparation and transportation, and the gasifier/cleanup unit, gas turbine, heat recovery system, and steam-cycle generator.

Table 3.2 summarizes the energy balance parameters for the system. As with $A F B C$, the power plant itself represents the largest energy invest- 
Table 3.1. Summary of AFBC Energy Parameters

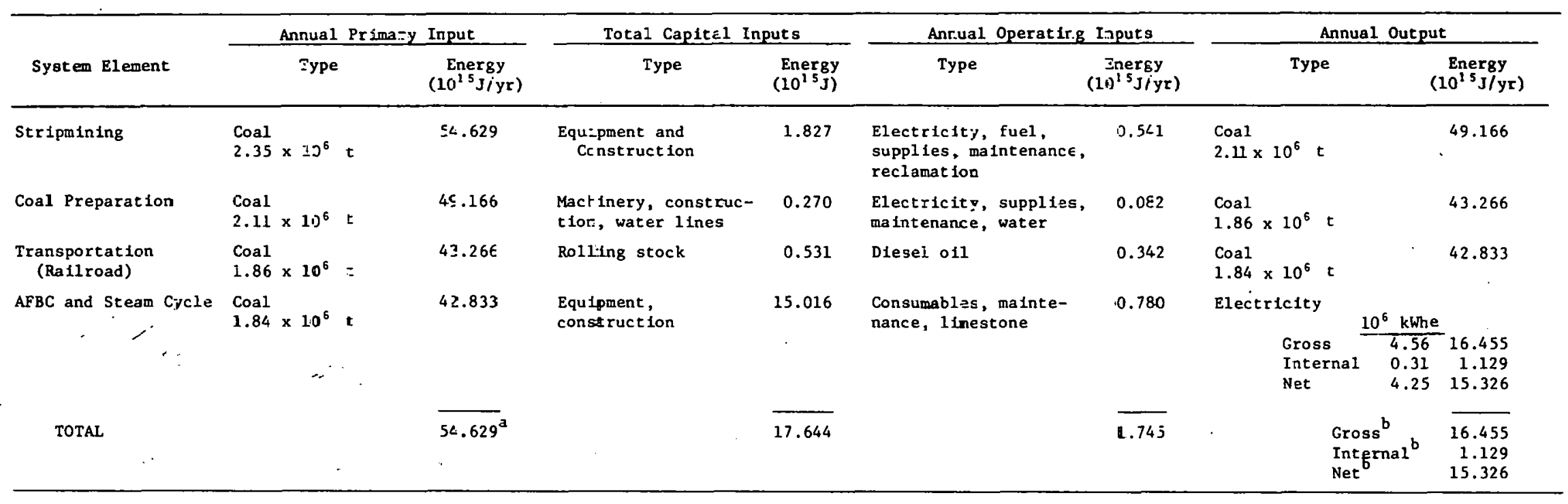

${ }^{a_{\text {Input }}}$ to entire cycle.

boutput from entire cycle. 
Table 3.2. Summary of Coal Gasification/Combined Cycle Energy Parameters

\begin{tabular}{|c|c|c|c|c|c|c|c|c|c|c|}
\hline \multirow[b]{2}{*}{ System Element } & \multicolumn{3}{|c|}{ Annual Primary Input } & \multicolumn{2}{|c|}{ Total Capital Inputs } & \multicolumn{2}{|c|}{ Annual Operating Inputs } & \multicolumn{3}{|c|}{ Annual Output } \\
\hline & \multicolumn{2}{|l|}{ Type } & \multirow{2}{*}{$\frac{\begin{array}{c}\text { Energy } \\
\left(10^{15} \mathrm{~J} / \mathrm{yr}\right)\end{array}}{41.442}$} & \multirow{2}{*}{$\begin{array}{l}\text { Type } \\
\begin{array}{l}\text { Equipment and } \\
\text { Construction }\end{array}\end{array}$} & \multirow{2}{*}{$\frac{\begin{array}{c}\text { Energy } \\
\left(10^{15} \mathrm{~J}\right)\end{array}}{1.383}$} & Type & \multirow{2}{*}{$\frac{\begin{array}{c}\text { Energy } \\
\left(10^{15} \mathrm{~J} / \mathrm{yr}\right)\end{array}}{0.410}$} & \multicolumn{2}{|c|}{ Type } & \multirow{2}{*}{$\frac{\begin{array}{c}\text { Energy } \\
\left(10^{15} \mathrm{~J} / \mathrm{yr}\right)\end{array}}{37.298}$} \\
\hline Stripmining & $\begin{array}{l}\text { Coal } \\
1.78 \times 10^{6} \mathrm{t}\end{array}$ & c. & & & & $\begin{array}{l}\text { Electricity, fuel, } \\
\text { supplies, maintenance, } \\
\text { reclamation }\end{array}$ & & $\begin{array}{l}\text { Coal } \\
1.61 \times 10^{6} \mathrm{t}\end{array}$ & 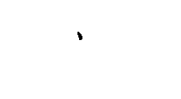 & \\
\hline Coal Praparation & $\frac{\text { Coal }}{1.61 \times 10^{6} t}$ & t & 37.298 & $\begin{array}{l}\text { Machinery, } \\
\text { construction, } \\
\text { water lines }\end{array}$ & 0.207 & $\begin{array}{l}\text { Electricity, supplies, } \\
\text { maintenance, water }\end{array}$ & 0.062 & $\frac{\text { Coa1 }}{1.42 \times 10^{6} t}$ & & 32.822 \\
\hline $\begin{array}{l}\text { Transportation } \\
\text { (Railroad) }\end{array}$ & $\frac{\text { Coal }}{1.42 \times 10^{6} \mathrm{t}}$ & t & 32.822 & Rolling stosk & 0.402 & Diesel ofl & 0.259 & $\begin{array}{l}\text { Coal } \\
1.40 \times 10^{6} t\end{array}$ & & 32.494 \\
\hline Gasif ler/Cleanup & $\begin{array}{l}\text { Coat } 1 \\
1.40 \times 10^{6}\end{array}$ & $\mathrm{t}$ & 32.494 & ------ (Included & Below)------ & $\begin{array}{l}\text { Dolomite, Internal } \\
\text { air, steam, water, } \\
\text { electricity }\end{array}$ & $\begin{array}{c}0.152 \\
(2.746)^{b}\end{array}$ & Low Btu gas & & 33.771 \\
\hline Gas Turbine & Low Btu Gas & & 33.771 & ------------ & $-----($ Incl & 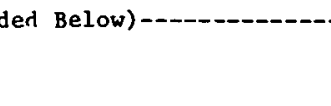 & --------- & $\begin{array}{l}\text { Internal a1 } \\
\text { Exhaust gas } \\
\text { Electricity }\end{array}$ & $r$, steam & $\begin{array}{r}1.663 \\
21.392 \\
10.503\end{array}$ \\
\hline Heat Recovery System & Exhaust Gas & & 21.391 & - & - Incl & ded Below) --_- & --------- & $\begin{array}{l}\text { Internal st } \\
\text { Steam to tu }\end{array}$ & $\begin{array}{l}\text { eam, water } \\
\text { rbine }\end{array}$ & $\begin{array}{r}0.657 \\
14.352\end{array}$ \\
\hline Stenm Cycle System & Steam & & 14.352 & - & ------ (Incl & ded Below) -- & -1----- & Electricity & & 5.512 \\
\hline \multirow[t]{2}{*}{ Power Transformer } & Electricity & & 16.015 & 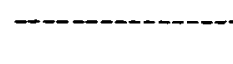 & - - - Inel & ded Below) - & -------- & Electricity & $0^{9}$ kWhe & \\
\hline & & & & & & & & $\begin{array}{l}\text { Gross } \\
\text { Internal } \\
\text { Net }\end{array}$ & $\begin{array}{l}4.43 \\
0.21 \\
4.22\end{array}$ & $\begin{array}{r}15.938 \\
0.735 \\
15.203\end{array}$ \\
\hline Total Plant & & & & Components & 13.641 & $\begin{array}{l}\text { Routine and } \\
\text { Special } O \& M\end{array}$ & 0.206 & & & \\
\hline TOTAL & & & $41.442^{\mathrm{a}}$ & & 15.633 & & 1.089 & & $\begin{array}{l}\text { Gross }^{c} \\
\text { Internal } \\
\text { Net } \\
\text { Ne }\end{array}$ & $\begin{array}{r}15.939 \\
3.055 \\
15.203\end{array}$ \\
\hline
\end{tabular}

${ }^{a}$ Input to entire system.

${ }^{b}$ Internal use - included in output total only.

Outpar from entire cycle.

${ }^{d}$ Ir.terial ir:cludes electricity, steam, air, water 
ment. The energy balance is somewhat complicated by the internal energy use: air, steam, and water are supplied to the gasifier from the gas turbine and heat recovery system; electricity is supplied from the overall plant output. In general, the system is more efficient than the AFBC configuration, as it uses about $25 \%$ less coal to deliver about the same amount of electricity.

\subsection{NUCLEAR SYSTEM}

The nuclear system analyzed is a conventional 1000-MWe light-water reactor (LWR), assumed to generate $5.34 \mathrm{x} 10^{9} \mathrm{kWhe} / \mathrm{yr}$ at a plant capacity factur of 61\%. Appendix $C$ gives the details of this system.

The overall system includes uranium mining, milllug, and transportation; conversion, enrichment, and fuel element fabrication; the reactor itself; spent fuel storage, and waste storage. Ordinary uranium ore, $0.208 \%$ $\mathrm{U}_{3} \mathrm{O}_{8}$ of which $0.71 \%$ is $\mathrm{U}^{235}$ with an enrichment tails assay of $0.2 \%$, is assumed. Reprocessing for recovery of unused uranium and plutonium. is not considered.

Table 3.3 summarizes the energy balance parameters. Although the reactor itself represents the largest energy investment, the enrichment process is the largest eonsumer of operatiug energy, most of which is in the form of electricity.

\subsection{TERRESTRIAL SOLAR ENERGY SYSTEMS}

Two teriestilal solar energy systems are considered: thermal and photovoltaic. Both are advanced technologies and could be available for commercial use at about the same time as an SPS. Appendix D gives the details of these systomo.

\subsubsection{Terrestrial Solar Thermal System}

The terrestrial solar thermal system assessed is a 100-MWe central receiver (power tower), designed by the McDonnell-Douglas Company. Glass flat-plate heliostats $(22,000)$ on tracking mounts focus sunlight on a receiver tower. The receiver/boiler and riser/downcomer provide heat and steam to the storage system and steam turbine; the storage system, designed to even out fluctuations in solar radiation, contributes about one-third of the input to the turbine. The turbine/generator and the balance of the electrical system use conventional components. 
Table 3.3. Summary of LWR Energy Parameters.

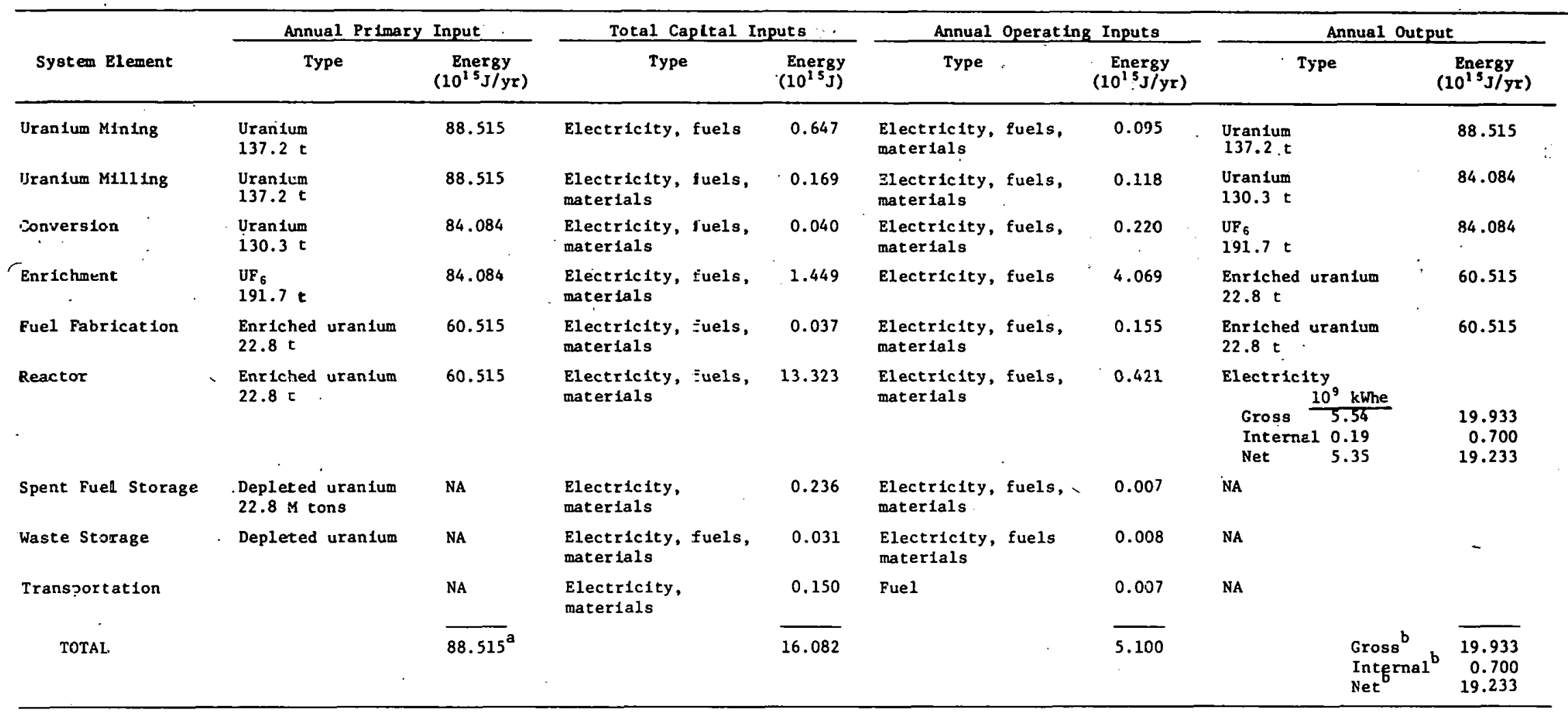

anput to entire cycle.

butput from entire cycle. 
Table 3.4 summarizes the energy parameters for the system. The collector represents the largest energy investment, accounting for $40 \%$ of the total. Operating energy is in the form of auxiliary electricity that is generated by the plant itself.

\subsubsection{Terrestrial Solar Photovoltaic System}

A 1000-MWe (peak) photovoltaic facility, operating $10 \mathrm{hr} /$ day at a capacity factor of $55 \%$, was analyzed. The system has limited storage capacity in the form of 1ithium/sulfur batteries to compensate for loss of insolation. The solar cells, assumed to be silicon, occupy an area of $52 \mathrm{~km}^{2}$; they are fitted with parabolic trough reflectors to concentrate solar radiation. Output from the cells is controlled by a power-conditioning module consisting of a DC collection network, regulator, controller, and inverter. An $\Lambda C$ distribution system and a transformer for matching to a utility grid also are included.

Table 3.5 summarizes the net energy parameters of this system: the capital energy investment is overwhelmingly dominated by the energy required to produce the silicon cells--73\% of the total, on the basis of the current state of the art of silicon manufacture. The implications of projected reductions in the cost of silicon cells and corresponding reductions in energy requirements will be discussed later. Steel required for the facility makes up an additional $17 \%$ of the capital energy investment.

\subsection{SATELLITE POWER SYSTEM (SPS)}

The Ers analyzed 10 based on llie latest concept definition prepared by NASA under the DOE/NASA SPS Concept Development and Evaluation Program.7 Two systems, using silicon cells and gallium aluminum arsenide cells respectively, were analyzed. Appondix F gives the detallo of the systems.

A single 5-GW satellite in geosynchronous orbit, transmitting power to earth via focused microwave beams, is ascumed. The system includes the ground rectenna, which receives and rectifies the microwave power, and the launch vehicle and orbital construction equipment. An analysis of the entire system (projected to use 60 satellites) would prorate the launch vehicles and other orbital construction equipment over all the satellites rather than 
Table 3.4. Summary of Terrestrial Solar Thermal Energy Parameters

\begin{tabular}{|c|c|c|c|c|c|c|c|c|}
\hline \multirow[b]{2}{*}{ System Element } & \multicolumn{2}{|c|}{ Annual Primary Input } & \multicolumn{2}{|c|}{ Total Capital Inputs } & \multicolumn{2}{|c|}{ Annual Operating Inputs } & \multicolumn{2}{|l|}{ Annual Output } \\
\hline & Type & $\begin{array}{l}\text { Energy } \\
\left(10^{15} \mathrm{~J} / \mathrm{yr}\right)\end{array}$ & Type & $\begin{array}{l}\text { Energy } \\
\left(10^{15} \mathrm{~J}\right)\end{array}$ & Type & $\begin{array}{c}\text { Energy } \\
\left(10^{15} \mathrm{~J} / \mathrm{yr}\right)\end{array}$ & Type & $\begin{array}{c}\text { Energy } \\
\left(10^{15} \mathrm{~J} / \mathrm{yr}\right)\end{array}$ \\
\hline Collector & Solar radiation & 10.775 & $\begin{array}{l}\text { Glass, s=eel, } \\
\text { concrete }\end{array}$ & 0.737 & ------- (Included & Below) ${ }^{a}-\ldots$ & Heat & 5.389 \\
\hline Recelver/Boller & Heat & 5.389 & Steel, concrete & 0.137 & & & Heat & 4.534 \\
\hline R1ser/Downcomer & Heat & 4.534 & Steel & 0.001 & ------- (Included & Below) ${ }^{a}-\ldots-$ & $\begin{array}{l}\text { Heat to storage } \\
\text { Steam to turbine }\end{array}$ & $\begin{array}{l}1.777 \\
2.711\end{array}$ \\
\hline Storage & Heat & 1.777 & $\begin{array}{l}\text { Caloric } 7 T 43 \text { oil, } \\
\text { sand, gravel, steel }\end{array}$ & 0.483 & ------ (Included & Bel ow) ${ }^{a}----\cdot-$ & Steam to turbine & 1.510 \\
\hline \multirow[t]{2}{*}{ Turbine/Generator } & Steam & 4.221 & Equipmen: & 0.324 & ---- (Included & Below) ${ }^{a}-\ldots$ & Electrictty & \\
\hline & & & & & & & \begin{tabular}{ll}
\cline { 2 - 2 } Gross & 3.62 \\
Internal & 0.13 \\
To transformer & 3.49
\end{tabular} & $\begin{array}{l}1.303 \\
0.046 \\
1.257\end{array}$ \\
\hline $\begin{array}{l}\text { Transformer/ } \\
\text { Power Conditioner }\end{array}$ & Electricity & 1.257 . & (Included in turb1ne/ge & enerator) & & & $\begin{array}{l}\text { Electricity } \\
\text { Net } 3.42 \times 10^{8} \mathrm{kWh}\end{array}$ & 1.230 \\
\hline Misc. Equipment & & & $\begin{array}{l}\text { Electricgl equipment, } \\
\text { cooling tower, } \\
\text { water transport }\end{array}$ & 0.136 & . & & & \\
\hline TOTAL & & $10.775^{b}$ & & 1.818 & & $--^{a}$ & $\begin{array}{l}\text { Gross }^{c} \\
\text { Internal }^{c} \\
\text { Netc }\end{array}$ & $\begin{array}{l}1.303 \\
0.046 \\
1.230\end{array}$ \\
\hline
\end{tabular}

'Input to ent1re cycle.

coutput from entire cycle. 
Table 3.5. Summary cf Terrestrial Solar Photovoltaic Energy Parameters

\begin{tabular}{|c|c|c|c|c|c|c|c|c|c|}
\hline \multirow[b]{2}{*}{ System Element } & \multicolumn{2}{|c|}{ Annual Prinary Input } & \multicolumn{2}{|c|}{ Total Capltal Inputs } & \multicolumn{2}{|c|}{ Annual Operating Inputs } & \multicolumn{3}{|c|}{ Annual Output } \\
\hline & Type & $\begin{array}{c}\text { Energy } \\
\left(10^{15} \mathrm{~J} / \mathrm{yr}:\right.\end{array}$ & Type & $\begin{array}{l}\text { Energy } \\
\left(10^{15}{ }_{J}\right)\end{array}$ & Type & $\begin{array}{c}\text { Energy } \\
\left(10^{1} 3 / \mathrm{J} / \mathrm{yr}\right)\end{array}$ & Type & & $\begin{array}{l}\text { Energy } \\
\left(10^{13} \mathrm{~J} / \mathrm{yr}\right)\end{array}$ \\
\hline & & $\cdot$ & & & & & & $10^{9} \mathrm{kWhe}$ & \\
\hline Collector & $\begin{array}{c}\text { Solar raciatior } \\
10 \mathrm{kWh}_{\mathrm{e}}\end{array}$ & 115.048 & silicon & $94.580^{\mathrm{a}}$ & ----- (Included & Below) ${ }^{D}-\cdots$ & Electricity & 2.18 & 7.830 \\
\hline $\begin{array}{l}\text { Power Regulator, } \\
\text { Controller, DC } \\
\text { Collection Network }\end{array}$ & $\begin{array}{c}\text { Elect }=1 \mathrm{1c1ty} \\
2.18\end{array}$ & 7.830 & Copper & 0.027 & - - (Included & 3elowi) ${ }^{b}---$ & $\begin{array}{l}\text { Electricity } \\
\text { To Battery } \\
\text { To Inverter }\end{array}$ & $\begin{array}{l}0.70 \\
1.43\end{array}$ & $\begin{array}{l}2.508 \\
5.165\end{array}$ \\
\hline Battery & $\begin{array}{c}\text { Elect }=1 \text { city } \\
0.70\end{array}$ & 2. 508 & Withium & 6.480 & -----(Includeć & 3elow) $b$ & $\begin{array}{l}\text { Electricity } \\
\text { To Inverter }\end{array}$ & 0.56 & 2.006 \\
\hline Inverter & $\begin{array}{c}\text { Electricity } \\
: . .99\end{array}$ & 7.171. & Equipment & 1.370 & & & Electricity. & 1.89 & 6.814 \\
\hline $\begin{array}{l}\text { AC Distribution } \\
\text { Line System }\end{array}$ & $\begin{array}{c}\text { Electric1ty } \\
\text { i.89 }\end{array}$ & 6.814 & ---N-C (Included Belon & w) ------ & & & $\begin{array}{l}\text { Electricity } \\
\quad \text { Gross } \\
\text { Internal } \\
\text { To transform }\end{array}$ & $\begin{array}{r}1.89 \\
10.07 \\
\text { ner } 1.82\end{array}$ & $\begin{array}{l}6.814 \\
0.238 \\
6.576\end{array}$ \\
\hline Transformer & $\begin{array}{c}\text { Electricity } \\
1.82\end{array}$ & 6.576 & E juipment & 1.940 & & & $\begin{array}{l}\text { Electricity } \\
\text { Net }\end{array}$ & 1.81 & 6.508 \\
\hline Entire Plant & & & $\begin{array}{l}\text { E-ectrical equipment, } \\
\text { s=eel, concrete }\end{array}$ & 24.566 & & & & & \\
\hline TOTAL & & $115.048^{c}$ & & 128.963 & & $--^{b}$ & & $\begin{array}{l}\text { Gross }^{d} \\
\text { Internal } \\
\text { Netd }\end{array}$ & $\begin{array}{l}6.814 \\
0.238 \\
6.508\end{array}$ \\
\hline
\end{tabular}

Based on state-of-the-art silicon production.

boperating infuts as internal ejectrieity use.

Input to entire cycle.

doutput from entire cycle. 
just the first one, but insufficient information was available to do so in the present study. The results, however, would not change much because vehicles and construction equipment make up a very small portion of the total materials energy required, and because the rocket fuel, which is a much larger portion of the construction energy required, was assessed for a single satellite only.

The energy parameters are summarized in Table 3.6. The energy needed for production of silicon cells dominates the balance, as was the case for terrestrial solar photovoltaic. The rectenna is the next largest consumer of capital energy for SPS/Si (it is the largest for SPS/GaAlAs) because of the aluminum and steel required. 
Table $\Xi .6$. Summary of SPS Energy Parameters

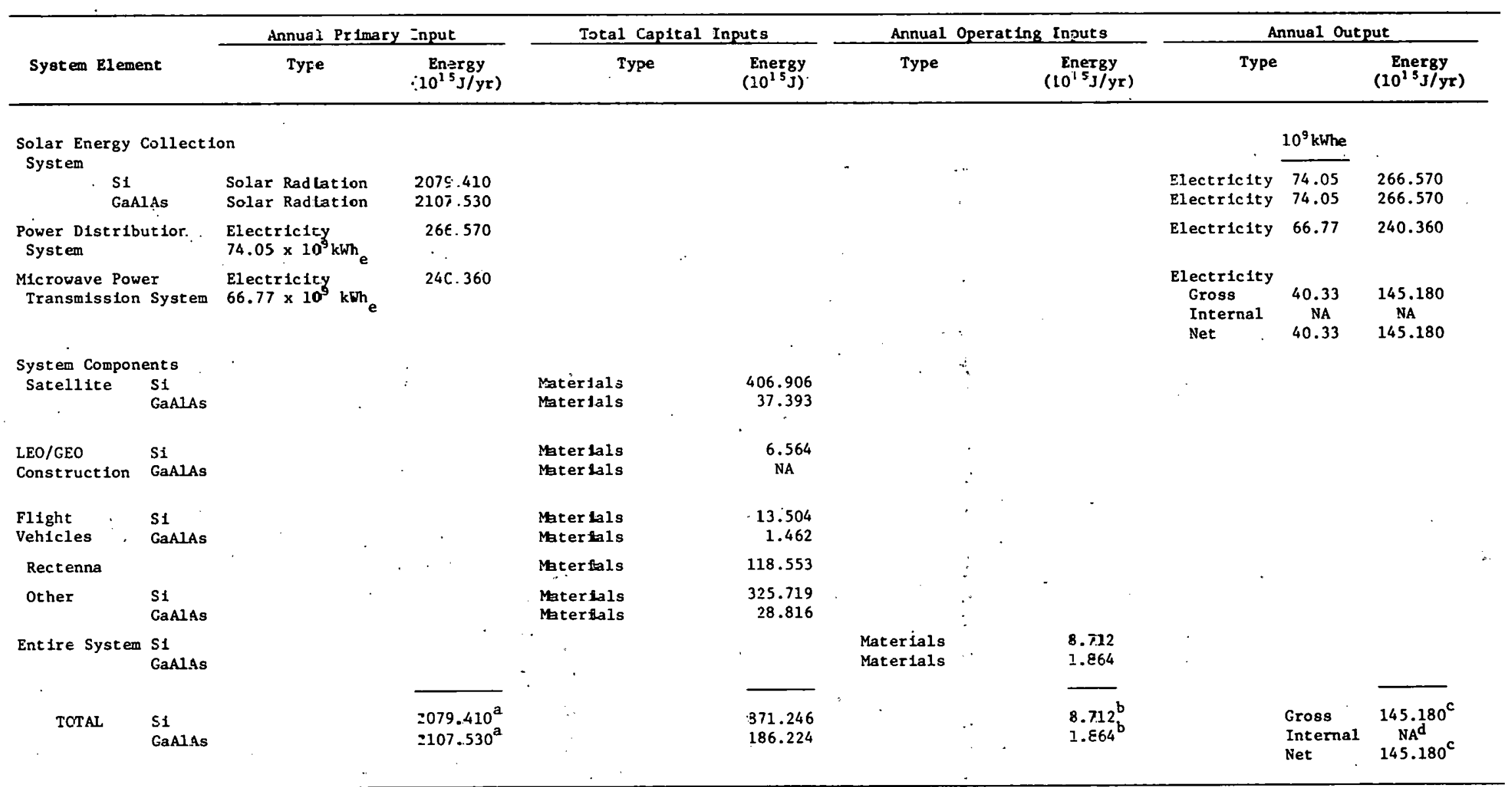

anput to entire system.

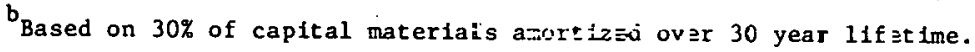

coutput from entire system.

dot avallable. 


\section{RESULTS OF ANALYSIS}

\subsection{BASELINE CASE}

Table 4.1 summarizes the energy inputs and outputs described in Sec. 3 for each of the systems considered. Because of the variation in system size ( 100 MWe for terrestrial solar thermal to 5000 MWe for SPS) and plant capacity factors, the values are not directly comparable. (In the net energy balance, discussed below, these differences disappear because the parameters of interest are normalized.)

All net output values are expressed in terms of electricity rather than as thermal equivalents; the importance of this will become apparent later. Likewise, all primary inputs are expressed as energy content of the fuel itself, with no adjustment factors applied. The capital and operating inputs, however, are computed using the net energy analysis techniques described in Sec. 2 and reflect both the energy cost of delivering materials to the facility and the energy content of the materials themselves.

The internal energy use includes electricity, compressed air, and steam. These differences in energy form, plus the differences in where internal electrical power is tapped in each system configuration, yield the consequence that the net output is not simply the difference between gross output and internal energy use.

Table 4.2 shows the energy balance parameters for the seven systems. The coal and nuclear systems are substantially more efficient than their solar cuulurparls in teims of gross, operating, and lifetime efficiency. However, the coal and nuclear systems operate from a nonrenewable resource base, whereas the solar energy systems operate from a renewable and effectively unlimited resource base, but the cost of resource depletion does not enter the calculation of efficiency. The three different measures of efficiency do not differ significantly because the numerator of each measure reflects the system output and the denominator includes the primary input, with various combinations of internal use and operating and capital inputs. The annual primary input is much larger, for all systems, than the annual operating input and internal use; also, the primary input is much larger than the capital input when both are expressed over the system lifetime for the lifetime efficiency calculation. The implication is that the efficiency with which the 
Tab-e 4.1. Stmmary of System Energy Inputs and Oucpuzs

\begin{tabular}{|c|c|c|c|c|c|c|c|}
\hline & \multicolumn{7}{|c|}{ Energy, $10^{15} \mathrm{~J}$} \\
\hline & \multicolumn{2}{|c|}{ Coai } & \multirow{2}{*}{$\begin{array}{c}\text { Nuclear } \\
\text { LWR } \\
1000 \mathrm{MWe}\end{array}$} & \multicolumn{2}{|c|}{ Terrestrial So-ar } & \multicolumn{2}{|c|}{ SPS } \\
\hline & $\begin{array}{c}\text { AFBC } \\
747 \mathrm{MWe}\end{array}$ & $\begin{array}{c}\text { CG/CC } \\
.41 .5 \mathrm{MWe}\end{array}$ & & $\begin{array}{l}\text { Thermal } \\
100 \text { MWe }\end{array}$ & $\begin{array}{c}\text { Photovolta:c } \\
1000 \mathrm{MNe}\end{array}$ & $\frac{\mathrm{s}_{\mathrm{i}}}{5000 \mathrm{MWe}}$ & $\begin{array}{c}\text { GaAlAs } \\
5000 \mathrm{MWe}\end{array}$ \\
\hline Annual Primary Input & 54.6 .29 & 41.442 & 88.515 & 10.755 & $115.0<8$ & 2079.410 & 2107.530 \\
\hline Total Capital Input & 17.644 & 15.633 & 16.082 & 1.818 & $128 . \subseteq \in 3$ & 871.246 & 186.224 \\
\hline $\begin{array}{l}\text { Annual Operating In ọut } \\
\text { Annual Outputs }\end{array}$ & 1.745 & 1.089 & 5.100 & $-c$ & $-c$ & 8.712 & 1.864 \\
\hline Gross ${ }^{a}$ & 16.455 & 15.938 & 19.933 & 1.303 & $6 . \varepsilon 14$ & 145.180 & 145.180 \\
\hline Internal Use ${ }^{b}$ & 1.129 & 3.355 & 0.700 & 0.046 & 0.238 & NA & NA \\
\hline $\operatorname{Net}^{a}$ & 15.326 & 15.203 & 19.533 & 1.230 & $6.5 \mathrm{C} 8$ & 145.180 & 145.180 \\
\hline
\end{tabular}

${ }^{2}$ Expressed as electricity.

bInternal includes electricity, air, steam. Because of differences in where the internal energy use is tappec from the system, the net out jut is not necessarily equal to the difference between gross and internal.

cInternal electricity only. 
Table 4.2. Summary of Energy Balance Data

\begin{tabular}{|c|c|c|c|c|c|c|c|c|}
\hline \multirow{2}{*}{\multicolumn{2}{|c|}{ Parameter }} & \multicolumn{2}{|c|}{ Coal } & \multirow{2}{*}{$\frac{\text { Nuc lear }}{\text { LWR }}$} & \multicolumn{2}{|c|}{ Terrestrial Solar } & \multicolumn{2}{|c|}{ SPS } \\
\hline & & $\mathrm{AFBC}$ & $\mathrm{CG} / \mathrm{CC}$ & & Thermal & Photovoltaic a & Silicon ${ }^{a}$ & GaAlAs ${ }^{a}$ \\
\hline 1 . & Gross Efficiency, \% & 28.1 & $\Xi 6.7$ & 21.7 & 11.4 & 5.7 & 7.0 & 6.9 \\
\hline 2 . & Operating Efficiency, \% & 26.7 & 33.4 & 20.4 & 11.4 & 5.7 & 7.0 & 6.9 \\
\hline 3 . & Operating Ratio & 5.33 & 3.67 & 3.32 & 26.74 & 27.34 & 16.67 & 77.89 \\
\hline & Lifetime Efficiency, $\%$ & 26.4 & $\vdots 3.0$ & 20.3 & 11.3 & 5.4 & 6.9 & 6.9 \\
\hline 5 . & Lifetime Ratio & 4.43 & 3.26 & 3.04 & 11.54 & 1.43 & 3.85 & 17.97 \\
\hline 6. & $\begin{array}{l}\text { Payback Period } \\
\text { (Electric Basis), yr }\end{array}$ & 1.30 & 1.11 & 1.14 & 1.48 & 19.82 & 6.38 & 1.30 \\
\hline
\end{tabular}

aThe data for the solar energy systems are limited and, in some cases, highly uncertain. Therefore, conclusions should be drawn with caution. 
primary energy resource is converted into electricity is relatively insensitive to the ancillary operating energy inputs and the capital energy inputs for these systems. The thermal or electric conversion efficiency of the system is thus the principal factor in determining system performance.

The situation is different with regard to the operating ratio and the 1 ifetime ratio, both of which are computed without consideration of the primary resource input. Operating ratios of the solar energy systems are much higher than those of coal and nuclear systems, indicating that much less energy is used annually to convert each unit of primary resource into electricity. Over the 1 ifetime of each system, however, the result changes dianalically. Fur the coal and nuclear systems, the operating and lifetime. ratios differ by, at most, $17 \%$ (for $A F B C$ ), whereas for the solar energy systems, the difference is $57 \%-95 \%$. The terrestrial photovoltaic and the SPS/Si systems show 1 ifetime ratios that are lower than the best coal system. (AFBC), whereas the terrestrial solar thermal and the SPS/GaAlAs systems have both operating and 1 ifetime ratios higher than those of the coal and nuclear systems. The implication is that the capital energy investment required to build each of the solar energy systems greatly reduces the net useful output of the systems over their lifetimes. This is not true of the coal and nuclear systems because the capital energy investments required are not as great relative to the energy output. For the terrestrial photovoltair and the Sys/Si systems, the decrease in net output makes them poorer performers than the best coal system. (As will be shown later, this is the result of the silicun production requirements.)

In contrast to the measures of efficiency, operating and 1 ifetime ratios are relatively sensitive to the ancillary operating, internal, and capital energy requirements. Small changes in these data can make relatively large changes in the ratios. Therefore the ratio calculations must be viewed as only rough gauges of system performance.

The energy payback period of each system is a somewhat less sensitive measure of overall energy balance. The payback period for all systems except the terrestrial photovoltaic and SPS/Si is less than $1.5 \mathrm{yr}$, indicating that five of the systems will deliver significantly more energy over their nominal 30-yr 1 ifetimes than was required to build them. Because the calculation is relatively insensitive to moderate changes in the data, it can be inferred 
that payback from these systems is reasonable; but the results are so similar among the five systems with short payback periods that they do not provide a clear basis for choosing among these systems.

The results are not encouraging for the terrestrial photovoltaic and the SPS/Si systems. The SPS/Si system requires over six years of operation to return the energy invested--more than four times longer than the worst of the other systems. Although this is not necessarily an unacceptable situation, it does demand closer investigation of the possibility of reducing the capital energy required. The terrestrial photovoltaic system requires almost $2 / 3$ of its entire lifetime to repay the energy investment. This slow payback, combined with a lifetime ratio of 1.43--1ittle more than the breakeven point of 1.0--leads to some serious concern over the viability of such a system, at least in the configuration used here.

In the following sections, the uncertainties in some of the data used in this baseline analysis will be considered, and different approaches to net energy analysis will be discussed, to illustrate the sensitivity of the results to alternative data and methods.

\subsection{EFFECT OF UNCERTAIN DATA}

\subsubsection{Energy Intensity of Silicon Cel1 Production}

For both the terrestrial photovoltaic and SPS/Si systems, the relatively poor performance compared to the other systems was traced to the very high energy requirements of silicon cell production. As shown in Appendix A, the energy requirements for silicon solar cell production vary over a wide range $\left(1.0 \times 10^{3}\right.$ to $\left.26.0 \times 10^{3} \mathrm{kWht} / \mathrm{kg}\right) .1,2,8,9$ The value used in the base1 ine case, $13.9 \times 10^{3} \mathrm{kWht} / \mathrm{kg}$, is derived from Ref. 9 and falls in the middle of the range. This value represents the current state of the art in silicon production technology. Substantial reductions in the cost of silicon cell production, and presumably in the energy required, are projected for the period when SPS is to be operational. Therefore, the impact of these reductions on the energy balance needs to be investigated.

Figure 4.1 shows the effect of using different levels of silicon energy intensity on the energy parameters. Because of the dominance of the primary energy input, there is essentially no effect on the lifetime efficiency. 

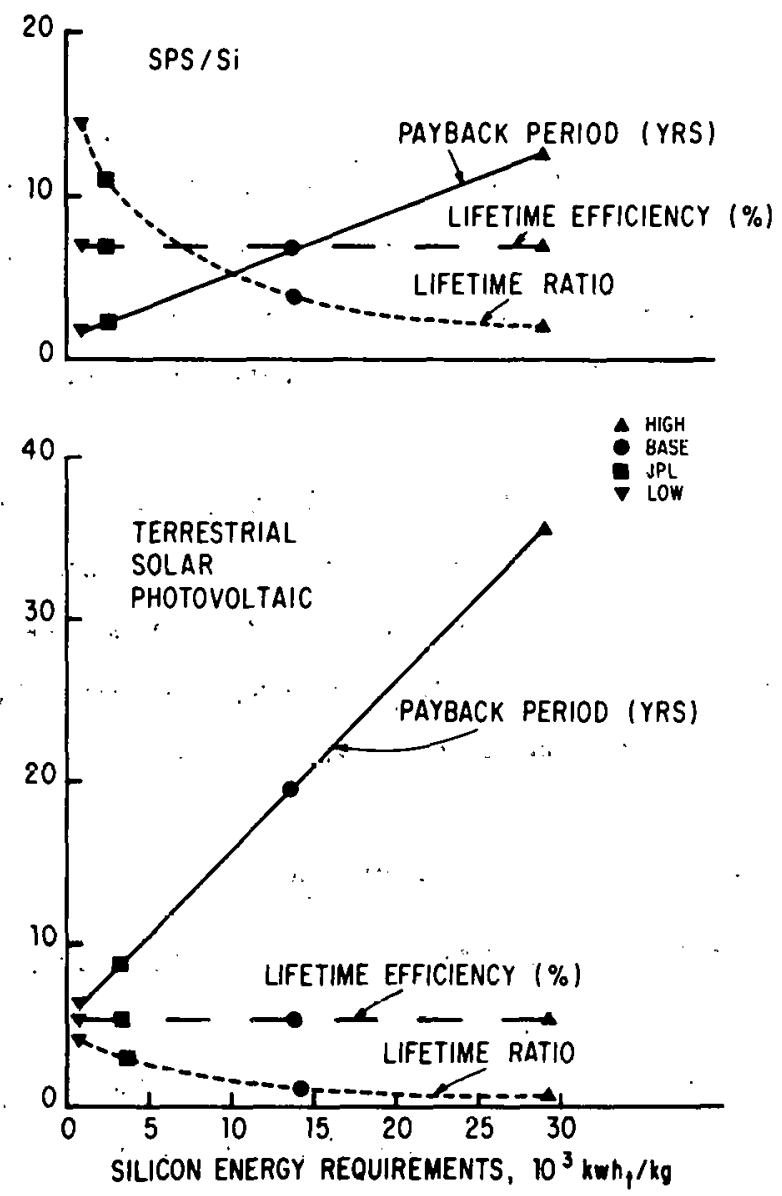

Fig. 4.1. Variation of Net Energy Parameters with Silicon Energy Requirements

The 1 ifetime ratio and the payback period could be significantly altered by reductions in this production energy. : By assuming the silicon production energy used in Ref. 2, the SPS payhạck poriod io reduced lu just over two years, and that of the terrestrial photovoltaic system to just over cight years. Use of the lowest estimates of production energy would put the SPS/Si system into: the same payback class as the other energy systemo and give lilu terrestrial photovoltaic system a somewhat more acceptable payback period of just nver six ycara.

The difference between the SPS/Si and the terrestrial photovoltaic system occurs because the SPS/Si. system would operate $24 \mathrm{hr} / \mathrm{day}$, as compared to about 8-10 hr/day for the terrestrial system, and after the capital energy investment has been made in the silicon cells, the SPS would use the material more intensively and thus more efficiently. 


\subsubsection{Cell Lifetime}

A fair amount of uncertainty exists as to the lifetime of silicon cells, either in geosynchronous earth orbit (GEO) or in the terrestrial environment. Reference 9 indicates a cell 1 ifetime of ten years in terrestrial applications; Ref. 7 assumes a $30-y r$ lifetime in orbit with some cell repair necessary. Obviously, a three-fold difference in cell 1 ifetime and, concomitantly, in the amount of silicon required; will affect the net energy balance similarly to a changed energy intensity of cell production. Experience is as yet insufficient to allow determination of the most realistic expected lifetime. For the purpose of this study it was assumed that the cells in both SPS/Si and terrestrial photovoltaic systems would have a 30 -yr 1 ifetime.

\subsubsection{Energy Supply for Silicon Production}

Most of the energy required for silicon production is needed as electricity for growing the crystals.9 All of the estimates of production energy cited above consider the electricity to be supplied by conventional generators; thus all are 1 imited by the thermal conversion efficiency of such equipment. (For input/output analysis as described in Appendix $A$, the energy cost of providing electricity is approximately four times the amount of electrical energy provided.) One method of reducing the energy requirements for silicon production would be to provide the electricity for cell manufacture from solar-power facilities instead of conventional fossil fuel or nuclear facilities. This would, in effect, reduce the silicon energy requirements by a factor of four. To account for this reduction, a dynamic analysis of the development of an entire solar electricity system would be needed, instead of the individual facility analysis made here. Although such a dynamic analysis is not within the scope of this study, a rough estimate of the impact of such a scenario may be obtained by simply viewing the use of solar electricity as a four-fold deçease in energy intensity and using Fig. 4.1. to determine the effect on the parameters. A four-fold decrease in the value used in this study for silicon production would reduce the payback period from $19.8 \mathrm{yr}$ to about $9 \mathrm{yr}$ for terrestrial photovoltaic, and from 6.4 yr to about $2 \mathrm{yr}$ for SPS/Si. With a four-fold decrease in the lowest estimate of silicon production energy, the payback would be about six years for terrestrial solar and one year for SPS/Si. (Reductions of smaller magnitude could also be realized for all the other systems if solar electricity were substituted for conventional electricity.) 


\subsubsection{Quantity of Silicon Required}

There is also some uncertainty, although of smaller magnitude, with respect to the amount of silicon required per MW of electrical output. Table 4.3 summarizes some of the different estimates. None of the different values would lead to a substantial difference in the outcome of the analysis, with the exception of the values for the average rather than peak power output for the terrestrial systems. In this analysis only values for the peak power rating were used.

\subsubsection{Energy Intenstity of GaAlAs Cell Production}

Uncertainties about the energy requirements for production of galium alluminum arsenide photovoltaic cells are much greater than the uncertaintieg about silicon. None of the other analyses of net energy for solar systems included GaAlAs as a candidate system, so very little information is available. The data for this study were based on Ref. 8; no other sources were discovered in the course of this preliminary review. The estimated energy intensity of $5.5 \times 10^{3} \mathrm{kWh} / \mathrm{kg}$ is about half as much as that required for silicon production. The quantity of GaAlAs required is almost an order of magnitude less (1696 t versus $13,813 \mathrm{t}$ ), primarily as the result of the higher efficiency GaAlAs and the use of concentrators in the cell configuration. It appears that GaAlAs cells require a much smaller energy investment than silicon cells ( $34 \times 10^{15} \mathrm{~J}$ versus $691 \times 10^{15} \mathrm{~J}$ ) for the same energy output.

Table 4.3. Differences in Silicon Requirements

\begin{tabular}{|c|c|c|c|c|}
\hline System & $\begin{array}{l}\text { Capacity } \\
\text { (MWe) }\end{array}$ & $\begin{array}{l}\text { Silicon } \\
\text { Required } \\
(t)\end{array}$ & $\begin{array}{l}\text { Intensity } \\
(t / M W e)\end{array}$ & Reference \\
\hline SPS/Si & 180,000 & $638, \cap \cap \cap$ & 1.45 & JPL $\frac{2}{3}$ \\
\hline SPS/Si & 5,000 & 13,813 & $2.76^{a}$ & $\mathrm{NASA}^{7}$ \\
\hline $\begin{array}{l}\text { Terrestrial } \\
\text { Photovoltaic (Peak) } \\
\text { (Average) }\end{array}$ & $\begin{array}{r}4,500 \\
900\end{array}$ & $\begin{array}{l}11,000 \\
11,000\end{array}$ & $\begin{array}{r}2.44 \\
12.22\end{array}$ & EPA $^{9}$ \\
\hline $\begin{array}{l}\text { Terrestrial } \\
\quad \text { Photovoltaic (Peak) }\end{array}$ & 1,000 & 1,890 & $1.89^{a}, b$ & $\mathrm{EPA}^{10}$ \\
\hline
\end{tabular}


Clearly, changes in the energy intensity or materials requirements of GaAlAs production will have a significant impact on the energy balance; however, more data are needed to evaluate the possible range of values.

\subsubsection{Other Material Energy Requirements}

Appendix A gives the ranges of energy intensity of the materials other than silicon that were analyzed. Because a complete materials 1 ist was not available for each of the technologies considered, a complete analysis of the effect of alternative ranges of energy intensity was not possible. However, a rough estimate $c$ an be made on the SPS requirements because a fairly comprehensive list of materials was available. Table 4.4 shows the effect on capital energy requirements and payback period, of using the low estimate and the high estimate of energy intensities from Appendix $A$, on the assumption that the silicon energy intensity is fixed at the baseline level. It is evident that variations in the energy requirements of other materials have very little effect on the payback period for either SPS/Si or SPS/GaAlAs.

\subsection{EFFECT OF ALTERNATIVE METHODS: OTHER STUDIES}

Reference 11 reviews the three earlier analyses of net energy that have been done on SPS.2,3,12 A11 three were done for preliminary SPS configurations somewhat different from the ones analyzed here, and so they cannot be compared directly to results presented here; nevertheless, it is informative to review the results and to attempt to explain some of the differences.

The PRC studyl2 was designed to be a rough, first-cut analysis of SPS energy balance and was conducted with input/output techniques only. All

Table 4.4. Effect of Energy Intensity Assumptions on SPS Energy Balance

\begin{tabular}{|c|c|c|c|c|c|c|c|}
\hline \multirow[b]{2}{*}{ Parameter } & \multirow[b]{2}{*}{ Units } & \multicolumn{2}{|c|}{ Baseline Values } & \multicolumn{2}{|c|}{ Low Intensity Values } & \multicolumn{2}{|c|}{ High Intensity Values } \\
\hline & & $\mathrm{Si}$ & GaAlAs & $\mathrm{Si}$ & GaAlAs & 51 & GuAlAs \\
\hline Toral Capilal Input & $\left(10^{15} \mathrm{~J}\right)$ & 871.246 & 186.22 .4 & 787.892 & 124.835 & 1116.145 & 421.171 \\
\hline Annual Operating Input ${ }^{b}$ & $\left(10^{15} \mathrm{~J} / \mathrm{yr}\right)$ & 8.712 & 1.862 & 7.879 & 1.248 & 11.161 & 4.212 \\
\hline Payback Period & (yrs) & 6.38 & 1.30 & $=5.74$ & 0.87 & 8.33 & 2.99 \\
\hline
\end{tabular}

axcept silicon, which is held at baseline value.

bchanges because operating input is computed as a fraction of capital input. 
SPS components were represented by cost figures and were converted to energy requirements using the standard approach. The calculation for a 5-GWe satel1ite using GaAlAs cells and a rectenna site, showed a capital energy requirement of $465 \times 10^{15} \mathrm{~J}$. This can be compared to the current study's estimate of $186 \times 10^{15} \mathrm{~J}$ for the same size satellite and rectenna. The difference can be traced primarily to the energy intensity values used in the two studies. The PRC analysis used strictly system component costs, whereas the present current study used a materials list. Also, the materials and cost requirements are different for each system because of an evolving system definition. If the PRC estimate of capital energy is translated into a payback period on the same basis as in the current study, the result is 2.5 years, which is comparable to the 1.3 years computed here.

The Herendeen study ${ }^{3}$ was conducted for an entire SPS consisting of 112 silicon-cell satellites of 10 GWe each. Several energy ratios are presented; the one that is closest to the 1 ifetime ratio used here is referred to as the "Energy Ratio, at $3413 \mathrm{Btu} / \mathrm{kWe,} \mathrm{fuel} \mathrm{excluded."} \mathrm{This} \mathrm{refers} \mathrm{to}$ the fact that the system output is expressed as electricity, and does not consider the efficiency of conventional power plants that generate the input electricity. The "fuel excluded" indicates that the primary resource input is not included in the calculation. Both of these assumptions are the same as those used in the present study to compute lifetime ratio. Herendeen's allalys1s shows a range of energy ratios from 0.5 to 3.9 , using a randomized uncertainty in energy intensity; the present study shows a lifetime ratio of 3.85. Considering the major difference in the assumption about silicon cell 1 ife, the values are surprisingly close. Herendeen considers an exponentially decreasing power output as the cells deteriorate over the system lifetime; however, this study assumes constant power output with cell repairs over a 30-yr 1 ifetime. Because the 1 ifetime energy ratio is a relatively sensitive parameter, small changes in data make significant changes in the ratios.

The JPL study 2 is also for an entire SPS including 48 satellites of 10 GWe each. It also is based on an earlier system design using silicon cells only. JPL computed energy intensity values by starting with process energy requirements for materials and multiplying by a factor of 2.5 to derive total materials of energy requirements, instead of using an input/output analysis based on economic costs. The JPL study used a multiplier of 4 to 
convert input electricity to total thermal energy equivalents, and a multiplier of 3 to convert output electricity to thermal equivalents. The first multiplier is basically consistent with the approach used here; but the second multiplier is not:" Although it can be argued that the sps output should be compared to the energy required to deliver that electricity from conventional generators, the across-the-board multiplication of the output by a factor of 3 appears arbitrary. Rather, it would seem more appropriate to consider the energy ratios as "joules of electricity output per joule of energy input" and to consider the payback period as the time over which the useful electrical output equals the useful thermal and electrical inputs. The JPL study ${ }^{2}$ shows a payback period of 1.2 to $1.6 \mathrm{yr}$, depending on the rectenna materials chosen. If the factor of 3 were removed from the output energy, then the payback period would be 3.6 to $4.8 \mathrm{yr}$. This is comparable to the $6.4 \mathrm{yr}$ reported here. The reason for the difference. lies primarily in the values used for energy requirements for silicon production. The: JPL value 2 is significantly lower (2.9 $\times 10^{3} \mathrm{kWh} / \mathrm{kg}$ versus $13.9 \times 10^{3} \mathrm{kWht} / \mathrm{kg}$ ) and represents projected improvements in the state of the art. Moreover, the quantity of silicon required is substantially less $(1.45 \mathrm{t} / \mathrm{MWe}$ versus $2.76 \mathrm{t} / \mathrm{MWe})$. These two factors yield the result that in the JPL study ${ }^{2}$ the SPS energy balance is more heavily dominated by the choice of aluminum or steel for the rectenna than by the silicon requirements. 
THIS PAGE

\section{WAS INTENTIONALLY LEFT BLANK}




\section{CONCLUSIONS AND RECOMMENDATIONS}

Three preliminary conclusions can be drawn from the present analysis. First, the calculation of system efficiency shows that the coal and nuclear systems are 2 to 5 times more efficient at extracting useful energy from the primary resource base than are the solar energy systems. This efficiency difference remains whether one uses gross, operating, or 1 ifetime parameters; it derives primarily from the electrical conversion efficiencies of the systems. However, because efficiency parameters cannot take into account the fact that the solar energy systems operate from a renewable and effectively inexhaustible resource base, whereas the nuclear and coal systems operate from a nonrenewable resource base, one must conclude that efficiency is not a good measure of comparability between the solar and the coal and nuclear systems.

Second, the operating ratio calculation shows that the solar energy systems require substantially less operating energy per unit of electrical output than do the coal and nuclear systems. Even the poorest of the solar energy systems (SPS/Si) has an operating ratio more than three times better than that of the best coal system ( $A F B C)$. The lifetime ratio, however, is greatly reduced (by $57 \%-95 \%$ ) below the operating ratio because of the intensive capital energy investment. For SPS/Si and terrestrial photovoltaic, the reduction is enough to drop them below the best coal system in performance.

Third, the payback period is less than $1.5 \mathrm{yr}$, except for the terrestrial photovoltaic system $(19.8 \mathrm{yr})$ and the SPS/Si $(6.4 \mathrm{yr})$. In both cases, this poor performance is caused by the energy required for silicon cell production. Several pussibilities, including reduction in the energy required for cell production, the use of solar-generated electricity in place of conventional electrical power, increased cell lifetime, and decreased silicon requirements, could reduce the SPS/Si payback period to a level that is comparable with the other systems considered (1-2 yr). However, for the terrestrial photovoltaic system, it appears that even the best combination of conditions would still require a payback period significantly longer than those of the other options (about $6 \mathrm{yr}$ ). (This is not necessarily a reason to consider terrestrial photovoltaic systems undesirable, as net energy balance is only one of several decision parameters.) 
Concerning the application of these results, it can be concluded that the energy payback period is a significant decision parameter only with respect to the choice of SPS/Si or terrestrial photovoltaic systems over the other systems. For the others, the computed payback. periods are so close as to be well within the range of error of the data, and it can be concluded that there is no difference. The operating and lifetime ratios show the expected results that the solar systems require much less operating energy than, the coal or nuclear systems but that the capital energy requirements greatly reduce this advantage. The terrestrial photovoltaic system is the poorest performer in this category... Although the efficiency calculations show the conventional systems to have higher efficiencies than the solar systems, the nature of the renewable versus nonrenewable resource base makes the cross-comparison difficult.

Recommendations for future activity include the following:

1. No further analysis is recommended for the coal, nuclear, and terrestrial solar thermal systems, because their payback periods are so similar; little can be gained by further comparisons of SPS with these systems.

2. More detailed assessment of energy requirements for production of silicon cells is needed, because the results for SPS/Si and terrestrial photovoltaic systems depend so heavily on this energy input. A study of the potential for reducing such energy consumption is recommended; and the net energy balance parameters for SPS/Si and terrestrial photovoltaic should be recomputed using the resultio of that otudy.

3. The energy inputs required for production of GaAlAs cells need study, and the net energy balance parameters for SPS/GaAlAs should be recomputed with the resulting new information. The information available at present is extremely limited, and although it suggests a very shore payback period the level of uncertainty dictates that it should be examined more carefully. 


\section{REFERENCES}

1. Frabetti, A.J., Jr., et al., Application of Net Energy Analysis to Consumer Technologies, Report No. DSI 047, Development Sciences Inc., East Sandwich, Mass (Dec. 22, 1976).

2. Livingston, F.R., et al., Satellite Power System Prelimninary Resource Assessment, Document No. 900-805, Rev. A., Jet Propulsion Laboratory, Pasadena, Calif. (Aug. 7, 1978).

3. Herendeen, R.A., Two Technologies Near the Net Energy Limit: Gasohol and Solar Satellite Power Station, Energy Research Group, University of Illinois at Champaign-Urbana (Aug. 1978).

4. Fraley, D.W., C.L. McDonald, and N.E. Carter, A Review of Issues and Applications of Net Energy Analysis, Battelle Pacific Northwest Laboratories, PNL-SA-6619 (May 1978).

5. Herendeen, R.A., and C.W. Bullard III, Energy Costs of Goods and Services 1963 and and 2967,' CAC Document No. 140, Center for Advanced Computation, University of Illinois at Champaign-Urbana (Nov. 1974).

6. Meyers, A.C., and A.E. Hildebrandt, Solar Tower-Thermal Collection Energy Component-10 MVe Pilot Plant, Proc. of the 1977 Annual Meeting, American Section of the International Solar Energy Society, Vol. 1 (1977).

7. Satellite Power System Concept Development and Evaluation Program Reference System Report, DOE/ER-0023, U.S. Department of Energy (Oct. 1978).

8. Woodcock, G.R., SPS Cost Consideration, Journal of Energy, Vo1. 2, pp.196-202 (July-Aug. 1978).

9. Gandel, M.G., et al., Assessment of Large-Scale Photovoltaic Materials Production, Report No. EPA-600/7-77-087, U.S. Environmental Protection Agency, Industrial Environmental Research Laboratory, Cincinnati, Ohio (Aug. 1977).

10 . Sears, R.D., D.V. Merrifield, and M.M. Perry, Environmental Impact Statement for a Hypothetical $1000 \mathrm{MWe}$ Photovoltaic Solar-Electric Plant, Report No: EPA 600/7-77-085, U.S. Environmental Protection Agency, Industrial Engineering Research Laboratory, Cincinnati, Ohio (Aug. 1977).

11. Kotin, A.D., Satellite Power System White Paper on Resource Requirements, Report No. SA-3, DOE/NASA SPS Concept Development and Evaluation Program, (Oct. 1978).

12. Bloomquist, C.E., A Survey of Satellite Power Stations, Report No. DSE/ 2071-1, Planning Research Corporation, Los Angeles (Sept. 1976). 
13. Personal communication with John M. Blocher, Jr. Research Associate, Materials Development Section, Battelle Columbus Laboratory (Nov. 1979).

14. Personal communication with Ralph Lutwock, Jet Propulsion Laboratory (Nov. 1979).

15. Blocher, J.M., Jr., and M.F. Browning, Evaluation of Selected Chemical Processes for Production of Low-Cost Silicon, DOE/JPL 954339-78/11 (July 9, 1978). 
39

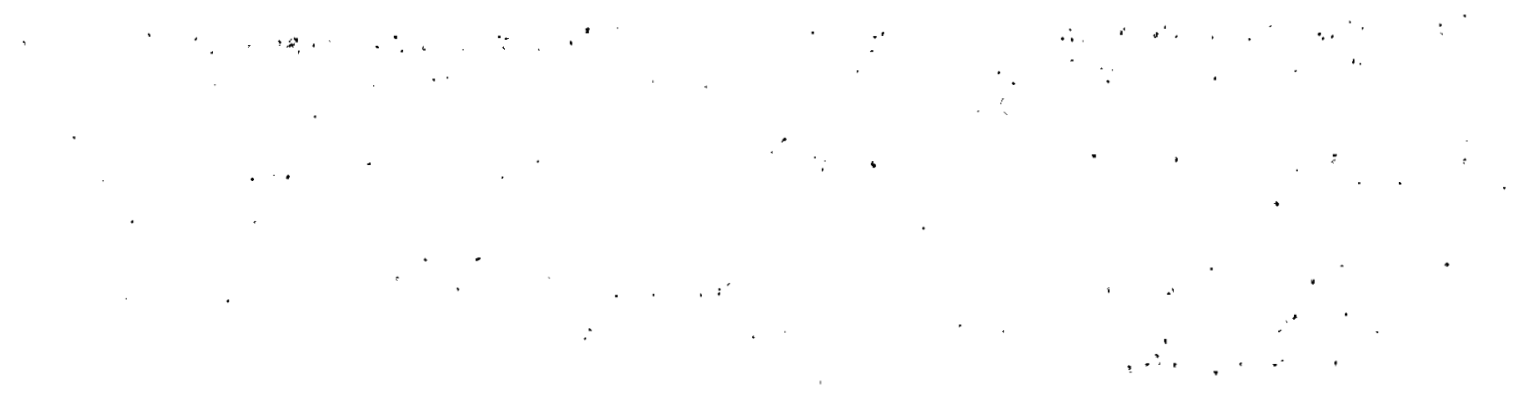

APPENDIX A

DETAILS OF THE METHODOLOGY

I 
c

THIS PAGE

\section{WAS INTENTIONALLY LEFT BLANK}




\section{A.1 BASIC STRUCTURE}

The energy technology system to be analyzed is first described as a series of elements that fall into the following categories:

Resource Extraction
Processing
Transportation
Conversion
Environmental Control

In the present analysis, the system boundary extends from the basic resource (e.g., coal in the ground or incident solar radiation) to the generation of electricity at the power plant. Specifically excluded from the analysis are the energy costs of exploration for resources and of research and development; these are beyond the scope of this preliminary evaluation.

Figure A.1 gives the basic structure of the net energy balance applied to each element of the system. The principal flows are the primary resource input; the ancillary operating inputs; the capital inputs; and the gross, net, and internal use outputs. The net output of one system element becomes the primary resource input to the next element in sequence.

The primary resource input is measured by a physical quantity and an energy content. In the case of coal, for example, the physical quantity is the tonnage of coal moved through the system; the energy content is the heating value of the coal. In the case of heat flow from a solar collector, the physical quantity is the volume of air or heat-exchange fluid, and the energy content is the heat content.

Ancillary operating inputs (A) are divided into three categories: electricity, fuels, and materials. These inputs represent the requirements for operating the system element on a daily basis. The ancillary electricity energy content (AEE) is the electricity that must be purchased from outside the element to run machinery, operate instruments, or provide energy for the process. In keeping with standard practice on net.energy analysis, the energy content of the ancillary electricity must have associated with it an ancillary energy cost (AEC) that reflects the primary fuel resource required to generate that electricity. Details of this calculation are described in Sec. A.3. 
Ancillary Operating Inputs, A

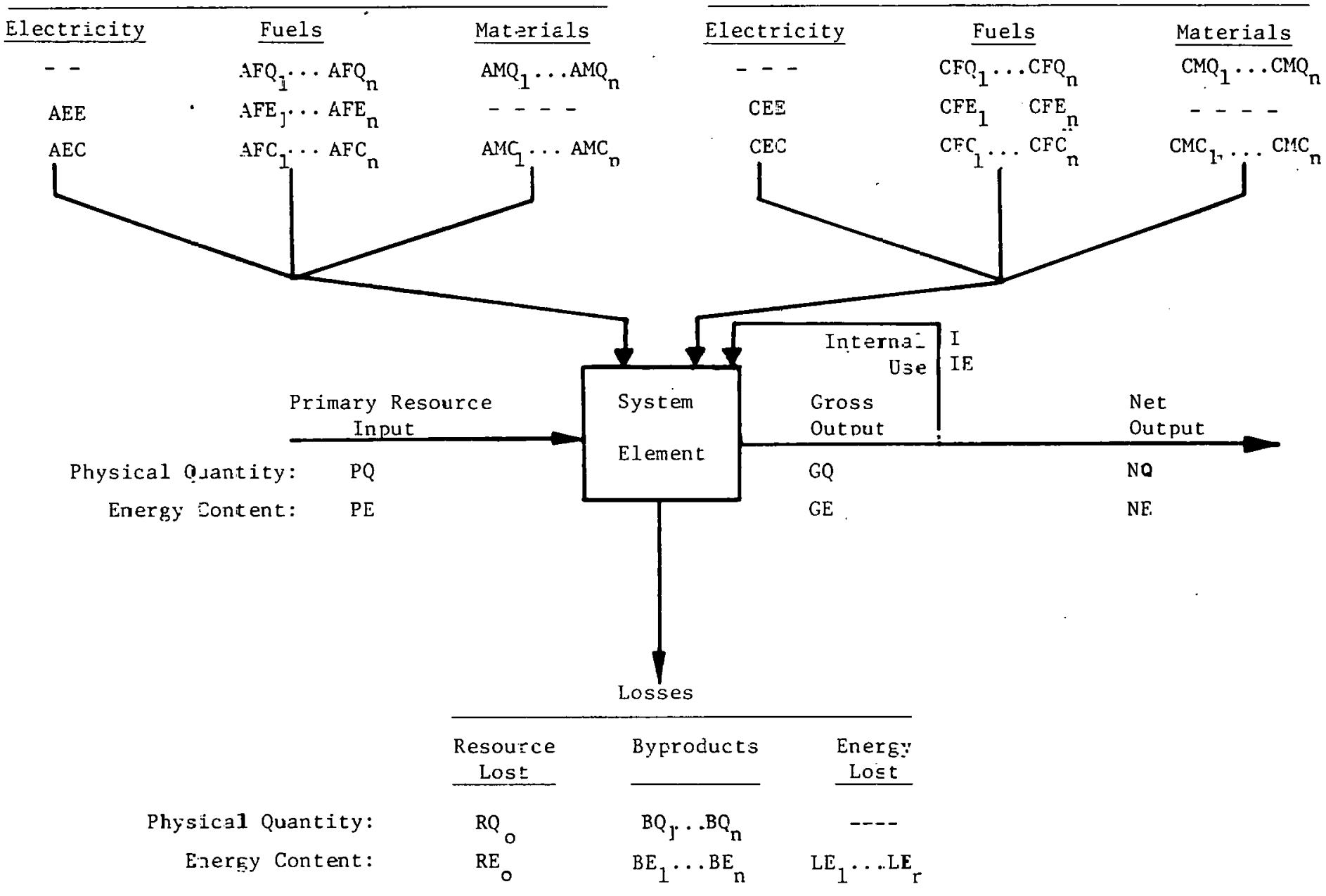

Fig. A.L. Schematic Chart of System Element Energy Balarce 
Ancillary fuels (AF) input into the system element are measured by three parameters: AFQ, the physical quantity (e.g., $\mathrm{m}^{3}$ of natural gas or gal of fuel oil); AFE, the energy content (e.g., the heating value of the fuel); and $A F C$, the energy cost required to produce and deliver the fuel to the system element. The first two items require straightforward calculations; Table A.l presents the fuel heating values used here. To determine the conversion from physical units to energy costs requires the use of input/output analysis, which is also described in Sec. A.3.

Ancillary materials (AM) input is measured by AMQ, the physical quantity (e.g. tons of steel or tons of concrete). By definition, there is no heating value in the material itself. The energy cost (AMC), is the energy required to produce and deliver the material to the plant site. This is calculated using input/output analysis or the material energy intensities described in Secs. A. 2 and A:4, respectively.

Capital inputs, (c) represent the energy required to construct the system element. They, are entirely analogous to the ancillary operating inputs, except that they are input over the lifetime of the system, in contrast to the annual inputs represented by the primary resource inputs and ancillary operating inputs. To incorporate capital inputs into the analysis, they are

Table A.1. Fuel Heating Values

\begin{tabular}{lcc}
\hline \multicolumn{1}{c}{ Fuel } & \multicolumn{2}{c}{ Heating Value } \\
\hline & $\frac{10^{9} \mathrm{~J} / \mathrm{m}^{3}}{41.7}$ & $\frac{\mathrm{Btu} / \mathrm{gal}}{149,690}$ \\
Heavy Diesel Fuel & 38.7 & 138,690 \\
Diesel and Light Fuel & 34.8 & 124,952 \\
Gasoline & 40.3 & 144,405 \\
Other Petroleum Products & 36.5 & 131,000 \\
Oil & $\frac{10^{7} \mathrm{~J} / \mathrm{kg}}{2.32}$ & $\frac{\mathrm{Btu} / 1 \mathrm{~b}}{10,000}$ \\
& 64,520 & $277.6 \times 10^{6}$ \\
Coal & $\frac{10^{7} \mathrm{~J} / \mathrm{m}^{3}}{3.92}$ & $\frac{\mathrm{Btu} / \mathrm{ft}^{3}}{1,051}$ \\
Uranium & 3.92 & 1,051 \\
\hline
\end{tabular}


either annualized by dividing by the system lifetime, or the other inputs are multiplied by system lifetime to obtain total energy flows. The simplifying assumption is used that level of operation is constant over the system lifetime. This is not an accurate reflection of actual conditions, but will suffice for this preliminary analysis.

Gross output (G) is the form of energy that results from operation of the system element. (Output may be in the same form as the primary resource input or it may be in a different form if the system element is a conversion process.) The internal use (IQ) is that quantity of the output product. that is consumed internally (e.g., electricity from a power plant used ta run equipment). The net oulpur (NQ) becomes the primary resource input to the next system element.

Losses are included in the diagram for the sake of completeness, but they are not used directly in any of the calculations; they are derived quantities computed by balancing inputs and outputs.

The expressions for the energy balance parameters can be presented in terms of these energy flows (meaning of abbreviations is shown in Fig. A.1) as follows:

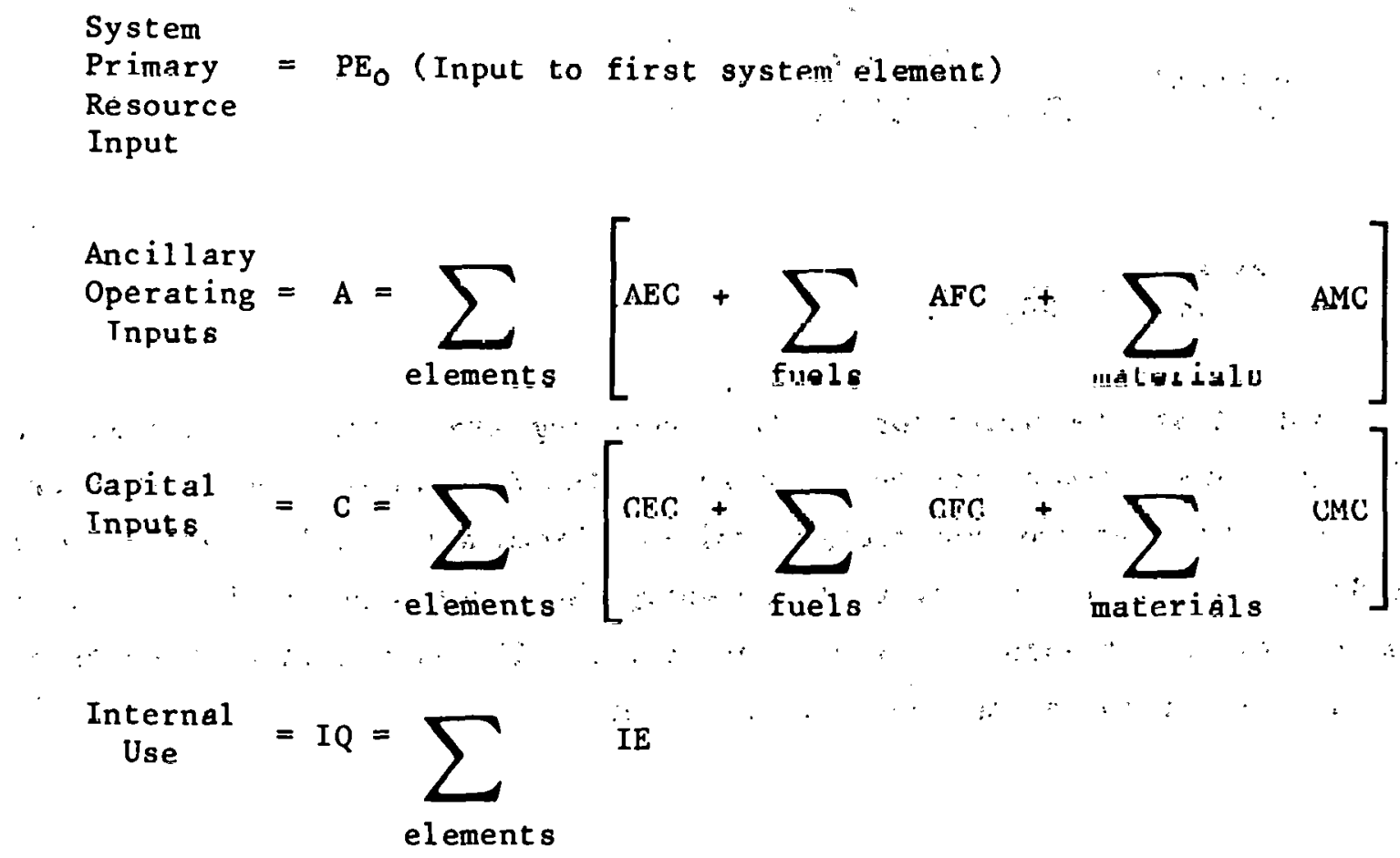


System

Net

Output

$=\mathrm{NE}_{\mathrm{f}}$ (Net output from final system element)

System $\quad=\tau$

Lifetime

$\underset{\text { Efficiency }}{\text { Gross }}=\frac{\mathrm{NE}_{\mathrm{f}}}{\mathrm{PE}_{\mathrm{o}}}$

$\underset{\text { Efficiency }}{\text { Operating }}=\frac{\mathrm{NE}_{f}}{\mathrm{PE}_{0}+\mathrm{A}+\mathrm{IQ}}$

$\underset{\text { Operationg }}{\text { Ratio }}=\frac{\mathrm{NE}_{\mathrm{f}}}{\mathrm{A}+\mathrm{IQ}}$

$\underset{\text { Efficiency }}{\text { Lifetime }}=\frac{\mathrm{NE}_{\mathrm{f}} \times \tau}{\left(\mathrm{PE_{0 }}+\mathrm{A}+\mathrm{IQ}\right) \times \tau+\mathrm{C}}$

$\begin{aligned} & \text { Lifetime } \\ & \text { Ratio }\end{aligned}=\frac{N_{E} \times \tau}{(A+I Q) \times \tau+C}$

$\begin{aligned} & \text { Payback } \\ & \text { Period }\end{aligned}=\frac{C}{\mathrm{NE}_{f}-\mathrm{A}}$

Note that the numerator in the operating and 1 ifetime efficiency and ratio equations includes net output only and the denominator includes internal use. This is standard net energy analysis formulation and is based on the consideration that if the internal use energy were not supplied by the system, it would have to be supplied by another source. Therefore, it must be treated as an additional operating energy requirement. 


\section{A.2 INPUT/OUTPUT ANALYSIS}

The details of an input/output analysis applied to net energy evaluation have been described in several studies. 1 The process involves the development of energy intensity values (expressed in $\mathrm{Bt} /$ / ) that represent the quantity of energy required per unit of output of a given product. Basic data used in many studies comes from work done by Herendeen and Bullard, 5 in which a 357-sector input/output model of the U.S. economy was constructed and used to develop energy intensity values. These values are expressed in terms of the primary energy resources (coal and crude oil) and electricity required to deliver a given dollar value of materials or finished product. The electricity values are in terms of the U.S. national average of primary resources required for electricity generation, given the structure of the U.S. utility system.

Application of the input/output technique followed the procedure outlined by DSI, Inc. ${ }^{1}$ In this procedure, several adjustments were made to the basic data from Herendeen and Bullard, which were derived for U.S. conditions in 1967. First, the electricity requirements were modified to account for a change in the structure of the utility system through the introduction of more nuclear and hydroelectric power since 1967. Second, the energy intensity of U.S. industry, which has changed since 1967, was factored in by adjusting the 1967 data by the energy consumption per dollar of GNP. Third, inflation was accounted for by adjusting the 1976 energy intensity values (Rt.u per 1967 dollar) to 1974 or 1975 dollars, depending on the data used. The inflation rates for various, sectors of the economy were used to make the adjustment more accurate for the period 1967-1974. Only one set of factors was available to adjust from 1974 dollars to 1975 dollars; these are summatized in Table A.2.

These revised 1974 and 1975 energy intensity values were used for those system compunents that were expressed in terms of cost. For material components the energy intensities per physical quantity (i.e., $\mathrm{kWh} / \mathrm{kg}$ ) given in Sec. A. 4 were used.

\section{A. 3 COMPUTATION OF ENERGY COSTS}

In many of the data sources used for the various systems, some of the operating energy and/or capital energy requirements are reported in 
Table A.2. Adjustments to Energy Intensity for

. Input/Output Analysis

\begin{tabular}{llc}
\hline \multicolumn{1}{c}{ Cause of Adjustment } & Cost Adjusted & Factor \\
\hline Structure of Utility Sector & Electricity & 0.61652 \\
Energy Intensity of Industry & Coal & 0.8838 \\
& Crude Oil & 1.0150 \\
& Electricity & 1.7869 \\
Inflation (1967-1974) & Coal & - a \\
& Crude Oil & - a \\
Inflation (1974-1975) & Electricity & $-a$ \\
& Coal & 0.9203 \\
& Crude Oil & 0.9203 \\
& Electricity & 0.9203 \\
\hline
\end{tabular}

avaried with economic sector (see ref. 5).

physical units (e.g., $\mathrm{kWh}$ of electricity, bbl of oil, $\mathrm{m}^{3}$ of gas). It is not adequate, however, to include only the energy content of the fuels in the energy balance; an accounting of the energy required to produce and deliver those fuels is necessary also. The input/output methodology of Refs. 1 and 5 provides coefficients that permit computation of the energy costs of delivered fuel. These coefficients, shown in Table A.3, have the units of Btu of primary energy required per Btu of fuel energy delivered in its final form. The energy content of the fuel used in the process is multiplied by the coefficient to account for the energy required to deliver that fuel. For this analysis, the fuel heating values in Table A.l were assumed. For electricity,

Table A.3. Energy Costs of Delivered Fuel

\begin{tabular}{lc}
\hline \multicolumn{1}{c}{ Fuel } & $\begin{array}{c}\text { Energy Cost } \\
\text { (Btu required/Btu delivered) }\end{array}$ \\
\hline Coal & 1.0060 \\
Refined Petroleum Products & 1.2082 \\
Gas & 1.1005 \\
Electricity & 3.7963 \\
\hline
\end{tabular}

Source: Ref. 1 . 
the quantity of electricity in $\mathrm{kWh}$ is first converted to Btu (3413 Btu/kWh) and then multiplied by the coefficient, which includes a factor for the thermal efficiency of electrical generation facilities. This process is applied only to the capital and operating energy requirements, and not to the primary energy input of the system.

\section{A.4 THE ENERGY INTENSITY OF MATERIALS}

\section{A.4.1 General Materials}

In some of the analyses, the quantities of materials involved in the construction and/or operation of a system are presented in physical units rather than in terms of energy costs. The energy intensities of these materials are shown in Table A.4 with the reported range of values and the value selected for this study.

Use of these intensities along with the intensities expressed in dollar costs in Sec. A.2 is consistent in that both represent total primary energy required at the point of manufacture. In the case of the Herendeen data $^{3}$ in Table A.4, an input/output economic analysis was used to develop the total energy requirements. In the case of the JPL data, ${ }^{2}$ the direct process energy required in manufacturing is arbitrarily multiplied by a factor of 2.5 to account for total energy requirements.

\section{A.4.2 Silicon Production}

Silicon production requires coke and electric power. Coke is used to reduce quartz $\left(\mathrm{SiO}_{2}\right)$ to metallurgical grade silicon in an arc furnace that is approximately $50 \%$ efficient. The silicon reacts with hydrochloric acid to yield trichlorosilane $\left(\mathrm{SiHCl}_{3}\right)$, which is admitted to a chamber containing an electrically heated silicun rod. The heat of the rod $(1370 \mathrm{~K})$ causes the $\mathrm{SiHCl}_{3}$ to decompose; the released $\mathrm{Si}$ deposits on the rod, which grows at about $1.44 \mathrm{~cm} /$ day. A suitable silicon ingot is produced in 3 to 4 days, and resistance heating of the rod during this period consumes about $70 \%$ of the electricity required by the procees.

The electrical power required to produce $0.11 \times 10^{5} \mathrm{t}$ of silicon cells annually (i.e., the quantity required for 4500 MWe peak output) is 4574 MWe.9 This process is assumed to be continuous, so the annual energy requirement is 
Table A.4. Material Energy Intensities

\begin{tabular}{|c|c|c|c|c|c|}
\hline \multirow{2}{*}{ Material } & \multicolumn{5}{|c|}{ Energy Intensity, $\mathrm{kWht} / \mathrm{kg}^{\mathrm{a}}$} \\
\hline & $\begin{array}{l}\text { Ref. } 3 \\
\text { Range }\end{array}$ & $\begin{array}{l}\text { Ref. } 2 \\
\text { Range }\end{array}$ & $\begin{array}{c}\text { Other } \\
\text { References }\end{array}$ & $\begin{array}{l}\text { Value } \\
\text { Used }\end{array}$ & Rationale for Selection \\
\hline GFRTP $^{b}$ & - & - & - & 179 & Use graphite value \\
\hline Stainless Steel & - & - & - & 26.5 & Mean of steel values \\
\hline Class & - & 49 & $3.22^{\mathrm{c}}$ & $49 / 3.22$ & $\begin{array}{l}\text { Use } 49 \text { for SPS, } 3.22 \text { for } \\
\text { terres. solar-different } \\
\text { types of glass }\end{array}$ \\
\hline Silicon & $1,900-26,000$ & 2,920 & $1,000-13,900^{d \cdots}$ & $-13,900$ & Current state-of-the-art \\
\hline Copper & - & 90 & . - & $71^{\cdots}$ & $\begin{array}{l}\text { Mean of copper and electronic } \\
\text { parts }\end{array}$ \\
\hline A l umi num & $66-83$ & $154-225$ & - & 145.5 & Mean \\
\hline Silver & - & 76 & - & 76 & - \\
\hline Molybde num & - & 76 & - & 76 & \\
\hline Mercury & - & - & - & 50 & Use "Other" \\
\hline Tungsten & - & - & - & 50 & Use "Other" \\
\hline Steel & $14-19$ & $27.2-39$ & $7.53^{\mathrm{C}}$ & 7.53 & , \\
\hline Concrete & $0.31-0.41$ & 2.3 & $1.00 \mathrm{c}$ & 1.00 & 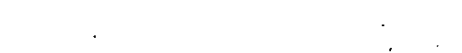 \\
\hline Gallium Arsenide & - & - & $5,500^{e}$ & 5,500 & $\dot{.}$ \\
\hline Titanium & - & - & - & 50 & Use "Other" \\
\hline Ceramics & - & - & - & 50 & Use "other". \\
\hline Misc. Organics & - & - & - & 50 & Use "Other" \\
\hline Argon & $7-11$ & 3.3 & - & 7.15 & Mean \\
\hline Hydrogen : & $1.4-2.3$ & 11.7 & - & 6.55 & Mean \\
\hline oxygen. & $3.3-4.2$ & 0.6 & - & 2.40 & Mean \\
\hline Methane Fuel & $14-15$ & 0.8 & - & 7.9 & Me an \\
\hline Sapphire & $\dot{-}$ & - & - & 38 & Uoe "Inoulation, Mylar, otc." \\
\hline Teflon & - & - & - & 38 & Use "Insulation, Mylar, etc." \\
\hline Kapton & - & - & - & 38 & Use "Insulation, Mylar, etc." \\
\hline Graphite & - & 179 & - & - & Not used di rectly \\
\hline Insulation & - & 38 & - & - & Not used directly \\
\hline Mylar & - & 38 & - & - & Not used directly \\
\hline Glue & - & 38 & - & - & Not used directly. \\
\hline Gold Kovar & - & 38 & - & - & Not used directly \\
\hline Electronic parts-SPS & $52-87$ & 87 & - & - & Not used directly \\
\hline Mechanical Systems-SPS & - & 50 & - & - & Not used directly \\
\hline Other & $66-83$ & 50 & - & 50 & \\
\hline Limestone & - & - & $0.08^{c}$ & 0.08 & \\
\hline Dolomite & - & - & - & 0.08 & Use limestone value \\
\hline Caloric HT43 oil & - & - & - & $13,508^{f}$ & $\begin{array}{l}\text { Use refl ned pecroleum prod. } \\
\text { Table A. } 2\end{array}$ \\
\hline S and and Gravel & - & - & $0.036^{\mathrm{c}}$ & 0.036 & \\
\hline
\end{tabular}

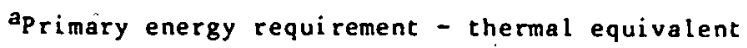

${ }^{b}$ Glass fiber reinforced thermo plastic

cref. 6

$d_{\text {Ref. } 8,9 \text { and Sec. A.4.2 }}$

e Ref. 9 and Sec. A.4.3

$\mathrm{f}_{\mathrm{kWh} t / \mathrm{m}^{3}}$ 
$4.007 \times 10^{10} \mathrm{kWhe.}$ This value yields an energy intensity of $3643 \mathrm{kWhe} / \mathrm{kg}$ of silicon cell, for a total energy cost (as discussed in Sec. A.3) of 13,800 $\mathrm{kWh} / \mathrm{kg}$. In addition, the process requires $21 \mathrm{~kg}$ of coke per $\mathrm{kg}$ of silicon cell. Assuming a heating value of $10,000 \mathrm{Btu} / \mathrm{lb}\left(23.24 \times 10^{6} \mathrm{~J} / \mathrm{kg}\right)$ and using the energy cost of coal from Sec. A.3 yields $140 \mathrm{kWh} / \mathrm{kg}$ of silicon cell. Thus the total energy requirement is $13,900 \mathrm{kWht} / \mathrm{kg}$ of $\mathrm{silicon}$ cells. This is the value used in the present baseline analysis.

Figure A.2 illustrates potential reductions in energy requirements as silicon manufacturing technology advances; 8 the lower 1 imit is about 1000 $\mathrm{kWht} / \mathrm{kg}$ of cells.

In addition to the advances in silicon manufacturing technology projected in Ref. 8, different technologies are emerging that may significantly reduce the energy consumption in various phases of polycrystalline silicon production. In all cases the $\mathrm{Si}$ single cell is produced from polycrystalline Si. Four such processes are the Acheson Process, 13 Westinghouse Arc Heater Process, 14 Battelle Zinc Reduction Process, 15 and the Union Carbide Silane Process. 14

The Acheson Process produces SiC (rather than metallurgical grade Si) from sand and sawdust using a very efficient resistance heating process with a

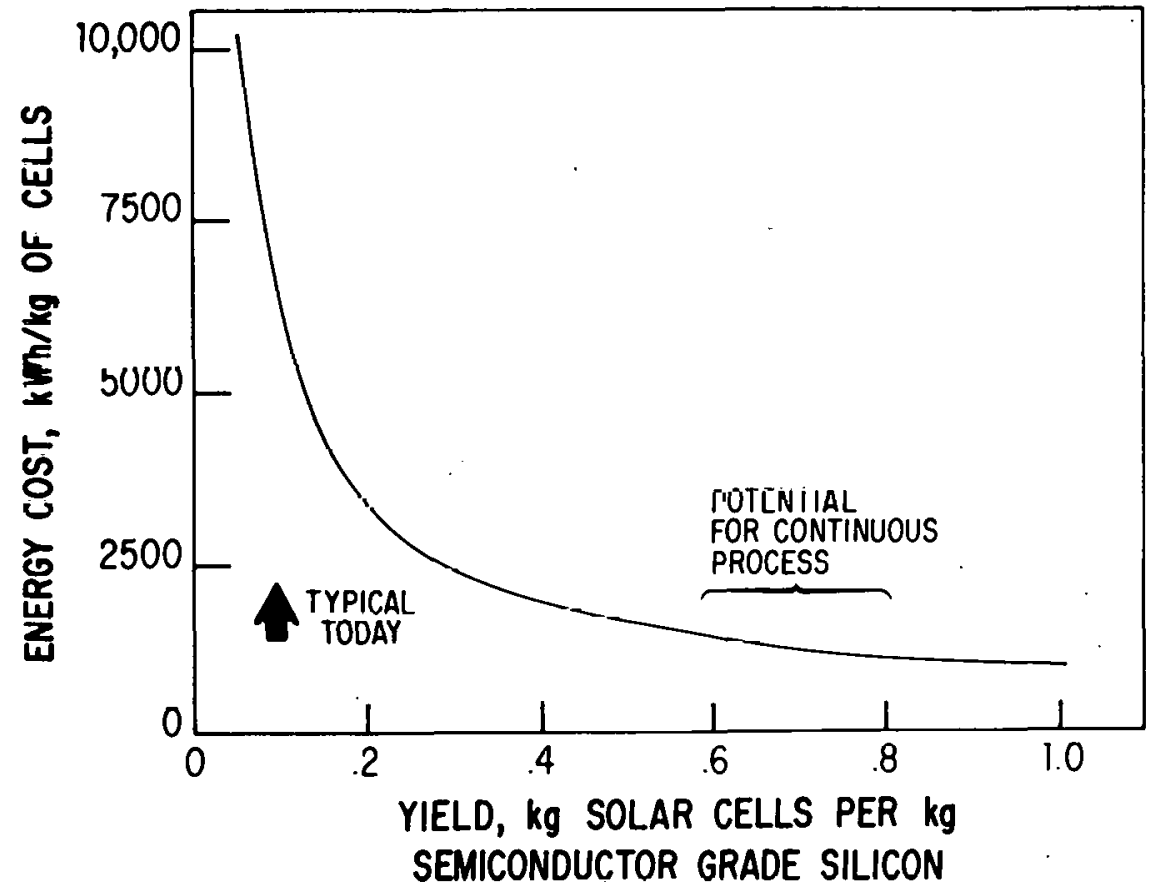

Fig. A.2. Potential for Reduction in Silicon Energy Requirements 8 
carbon rod. The Westinghouse Arc Heater Process starts with the preparation of $\mathrm{SiCl}_{4}$ from SiC and produces polycrystalline silicon. The Battelle Zinc Reduction Process produces polycrystalline silicon starting with the reduction of $\mathrm{SiCl}_{4}$ with zinc. The $\mathrm{SiCl}_{4}$ can either be purchased or produced from metallurgical grade $\mathrm{Si}$ or SiC. The Union Carbide Silane process also produces polycrystalline Si, starting with metallurgical grade Si. All of these appear to have the potential for reducing the energy requirements of silicon production significantly below those used in this analysis.

\section{A.4.3 Gallium Aluminum Arsenide Production}

Very few data are available on gallium arsenide production requirements. The electrical power required for the annual production of enough GaAlAs to make cells to yield 100 MWe (peak power) of electricity is 57.98 MWe. 9 The process is assumed to be continuous, so the energy requirement is $5.08 \times 10^{8} \mathrm{kWhe}$. Cell requirements are $3.69 \mathrm{t}$ per peak MWe, which"yields an energy intensity of $1377 \mathrm{kWhe} / \mathrm{kg}$ of cells. Using the energy costs of electricity from Sec. A.3 yields $5500 \mathrm{kWht} / \mathrm{kg}$ of cells. This value was usëd here.

No information was available on potential energy reductions. 


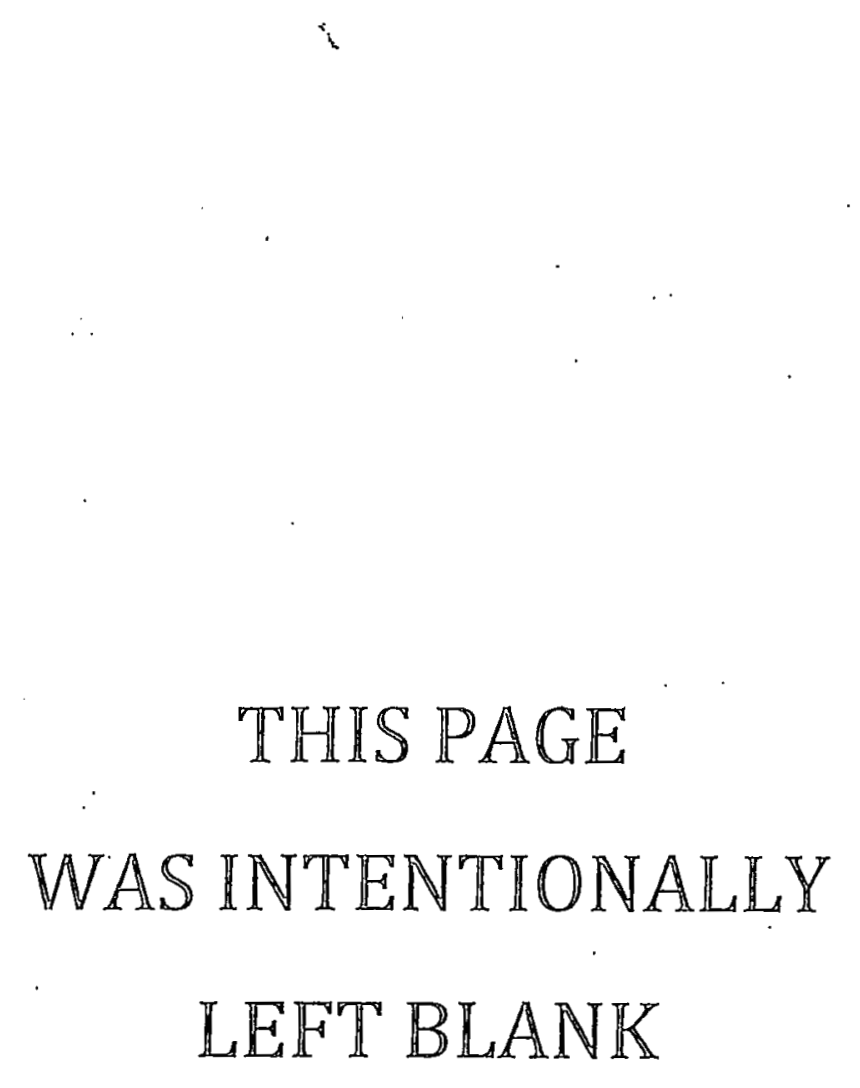


REFERENCES TO APPENDIX A

1. Frabetti, A.J., Jr., et al., Application of Net Energy Analysis to Consumer Technologies, Report No. DSI 047, Development Sciences Inc., East Sandwich, Mass (Dec. 22, 1976).

2. Livingston, F.R., et al., Satellite Power System Prelimninary Resource Assessment, Document No. 900-805, Rev. A., Jet Propulsion Laboratory, Pasadena, Calif. (Aug. 7, 1978).

3. Herendeen, R.A., Two Technologies Near the Net Energy Limit: Gasohol and Solar Satellite Power Station, Energy Research Group, University of Illinois at Champaign-Urbana (Aug. 1978).

4. Fraley, D.W., C.L. McDonald, and N.E. Carter, A Review of Issues and Applications of Net Energy Analysis, Battelle Pacific Northwest Laboratories, PNL-SA-6619 (May 1978).

5. Herendeen, R.A., and C.W. Bullard III, Energy Costs of Goods and Services 1963 and and 2967, CAC Document No. 140, Center for Advanced Computation, University of Illinois at Champaign-Urbana (Nov. 1274).

6. Meyers, A.C., and A.E. Hildebrandt, Solar Tower-Thermal Collection Energy Component-10 Me Pilot Plant, Proc. of the 1977 Annual Meeting, American Section of the International Solar Energy Society, Vol. 1 (1977).

7. Satellite Power System Concept Development and Evaluation Program Reference System Report, DOE/ER-0023, U.S. Department of Energy (Oct. 1978).

8. Woodcock, G.R., SPS Cost Consideration, Journal of Energy, Vo1. 2, pp.196-202 (July-Aug. 1978).

9. Gandel, M.G., et al., Assessment of Large-Scale Photovoltaic Materials Production, Report No. EPA-600/7-77-087, U.S. Environmental Protection Agency, Industrial Environmental Research Laboratory, Cincinnati, Ohio (Aug. 1977).

10 . Sears, R.D., D.V. Merrifield, and M.M. Perry, Environmental Impact Statement for a Hypothetical 1000 Me Photovoltaic Solar-Electric Plant, Report No. EPA 600/7-77-085, U.S. Environmental Protection Agency, Industrial Engineering Research Laboratory, Cincinnati, Ohio (Aug. 1977).

11. Kotin, A.D., Satelzite Power System White Paper on Resource Requirements, Report No. SA-3, DOE/NASA SPS Concept Development and Evaluation Program, (Oct. 1978).

12. Bloomquist, C.E., A Survey of Satellite Power Stations, Report No. DSE/ 2071-1, Planning Research Corporation, Los Angeles (Sept. 1976). 
13. Personal communication with John M. Blocher, Jr. Research Associate, Materials Development Section, Battelle Columbus Laboratory (Nov. 1979).

14. Personal communication with Ralph Lutwock, Jet Propulsion Laboratory (Nov. 1979).

15. Blocher, J.M., Jr., and M.F. Browning, Evaluation of Selected Chemical Processes for Production of Low-Cost Silicon, DOE/JPL 954339-78/11 (July 9,1978 ). 
APPENDIX B

COAL FUEL CYCLE SYSTEMS 
THIS PAGE

WAS INTENTIONALLY

LEFT BLANK 


\section{APPENDIX B}

COAL FUEL CYCLE SYSTEMS

This appendix will address two coal-based systems: atmospheric fluidized-bed combustion and gasification/combined-cycle facilities.

\section{B.1 FLUIDIZED-BED COMBUSTION}

\section{B.1.1 Description of the Overall System}

The system analyzed is a coal-fired steam generation cycle with the atmospheric fluidized-bed combustion (AFBC) furnace, designed by the General Electric Company. The system is designed to deliver electricity to a utility grid and includes a 747-MWe power plant generating $15,326 \times 10^{12} \mathrm{~J} / \mathrm{yr}(4.25 \times$ $10^{9} \mathrm{kWh} / \mathrm{yr}$ ) with a plant capacity factor of $65 \%$.

Figure B.l shows a simplified flow diagram of a coal fuel cycle for the $A F B C$ system. In addition to mining, preparation, and transportation of coai, separate unit processes in the AFBC system are merged into two subsystems: the conversion system and the steam cycle system. These subsystems are used to calculate separate energy balances for the overall system performance. Energy balances for each subsystem are calculated on the basis of the electrical output of $15,326 \times 10^{12} \mathrm{~J} / \mathrm{yr} .1-3$ The 1 ifetime of a power plant is assumed to be 30 yi.

\section{B.1.2 System Elements}

The net energy analysis for a coal fuel cycle depends on many complex factors, such as geographic location, mining methods, coal-preparation options, transportation, prices of ancillary energy, capital requirements, manpower and material availabilities, and environmental regulations. In this section, the elements of the AFBC system are discussed briefly.

Resource Extraction. Two types of coal mining procedures are used in the United States: strip mining and underground mining. Some $545 \times 10^{6}$ t* of coal were mined in the U.S. in 1973.4 This is a $14 \%$ increase since 1965;

\footnotetext{
*t is the abbreviation for metric ton $(1000 \mathrm{~kg})$; the Englieh ton is not
} abbreviated. 


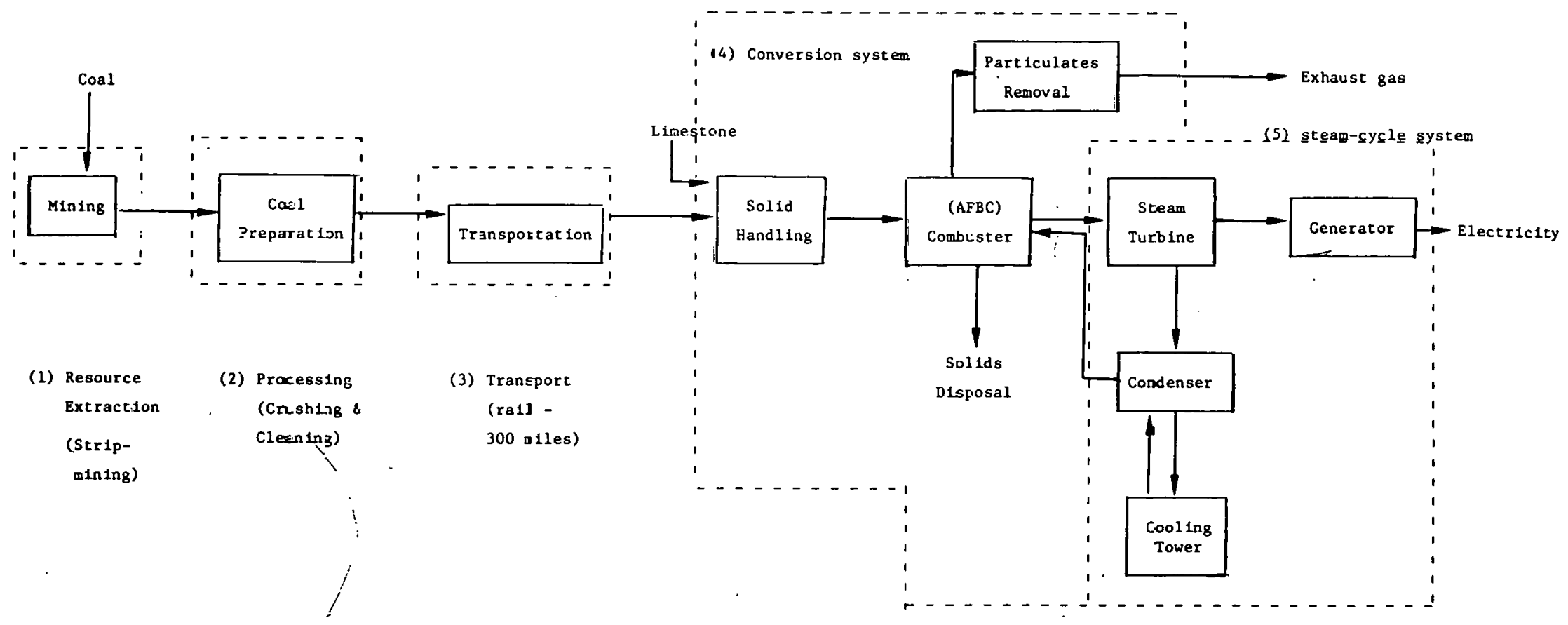

Fis. . B.1. Simplified Flow Diagram of an AFBC Cycle 
however, most of this increase has occurred in the western coal fields where surface mining methods are used, and total underground mining has decreased. 4 Therefore, only surface mining is considered in this study.

Typical energy contents of coal generally range from about $16.3 \times 10^{9}$ $\mathrm{J} / \mathrm{t}(7,000 \mathrm{Btu} / 1 \mathrm{~b})$ for 1 ignite to over. $32.6 \times 10^{9} \mathrm{~J} / \mathrm{t}(14,000 \mathrm{Btu} / 1 \mathrm{~b})$ for anthracite. The coal studied here is assumed to be a bituminous coal with a heating value of $23.2 \times 10^{9} \mathrm{~J} / \mathrm{t}(10,000 \mathrm{Btu} / 1 \mathrm{~b})$.

A typical strip-mined coal bed is 2 mide with an overburden averaging $22 \mathrm{~m} .1$ The overburden is blasted with an ammonium nitrate-fuel oil mixture and removed by electric shovels of $92-\mathrm{m}^{3}$ capacity.l Overburden drills, stripping equipment, coal loading shovels, pumps, and lighting equipment are operated by electric power. About $90 \%$ of the deposited coal is assumed to be recovered in surface mines; $;^{-4}$ only $50 \%$ to $60 \%$ of the coal may be recovered in an underground mine using room-and-pillar methods.

Land reclamation costs, including handling and treatment of the preparation $\mathrm{plant}$ refuse, are estimated at $\$ 494,000$ per $\mathrm{km}^{2}(\$ 2,000$ per acre). 1

Processing. Coal may be prepared (beneficiated) before, transportation to upgrade its value and remove potential envirommental pollutants. The preparation assumed in this study consists of mechanical cleaning and separation of particles of coal from impurities. (About $60 \%$ of total U.S. coal output undergoes some kind of mechanical cleaning and processing.) 5

Coal preparation generally is accomplished at or near the mine site, and it involves any combination of the following steps: 5

- Crushing and screening to achieve desired size range and to remove part of the impurities.

- Removal of dust and heavier mineral impurities (including pyritic sulfur) through techniqués based on specific gravity, centrifugation, and differences in surface characteristics.

- Thermal drying to prepare the coal for shipping or use.

In this study, the coal preparation plant was assumed to be located at the mine mouth, and a $16 \mathrm{~km}$ (10 mi) pipeline to bring water to the plant is required. An allowance for a coal loading facility is included in the plant 
costs. Rail tracks for coal transportation away from the plant are assumed to exist already. In the course of crushing and cleaning, $12 \%$ of the heating value was assumed to be lost. 1

Transportation. Transportation options include rail, barge, slurry pipeline, truck, and conveyor. Trucks and conveyors normally are used either in conjunction with another mode of transportation or between mines and nearby conversion facilities; barges, of course, require the proximity of a river or canal. Slurry pipelines represent a reasonably new technology; their main disadvantages are high capital costs, substantial water requirements, and the inflexibility of pick-up and delivery points. Their major advantage is luw operacling cost for high-volume, long-distance coal transport. In 1974, about $75 \%$ of all U.S. coal was moved by rail; in 1972 the average haul distance distance was $453 \mathrm{~km}(283 \mathrm{mi}) .4$ In this study, coal was assumed to be transported $480 \mathrm{~km}(300 \mathrm{mi})$ by rail to a coal conversion plant. About $1 \%$ of coal was estimated to be lost during transportation.

Conversion. Fluidized-bed coal combustion is a technique for burning coal in a bed of granular, noncombustible material such as limestone or dolomite. The bed is supported by a distributor plate, and air is passed up through the distributor plate to suspend or fluidize the bed particles. Heat generated is removed by heat-transfer tubes placed in the bed. There are three types of fluidized-bed combustors: atmospheric fluidized-bed combustors $(A F B C)$, pressurized fluidized-bed combustors ( $P F B C$ ), and pressurized fluidized-bed adiabatic combustors. 6,7

The system analyzed in this study is the AFBC process designed by the General Electric Co. for the ERDA-sponsored Energy Conversion Alternatives Study (ECAS) - Phase II studies. 2,3 AFBC was chosen for use here because it is a simpler process and is comparable with the other proresses in terms of overall performance.

For the AFBC unit, there, is no pressure differential to consider, and a conventional steam turbine can be used. For the pressurized unito, $a$ gas turbine is required in addition to the steam turbine to extract all the energy of combustion. This necessitates a high-temperature, high-pressure gas cleanup, which is more difficult than low-temperature, low-pressure gas cleanup. 7 
The AFBC and PFBC systems designed by G.E. have been compared,2,3 and the results show that the overall efficiency of the AFBC system (35.8\%) is about 3.4 percentage points lower than that of the PFBC system (39.2\%). The cost of electricity (COE) of the AFBC ( $31.7 \mathrm{mills} / \mathrm{kWh}$ ) is about 2.4 mills/kWh less than the PFBC's COE (34.1 mill $/ \mathrm{kWh}) .^{3}$ Therefore, the AFBC system requires more ancillary energy but involves a lower cost to produce the same amount of electricity, mainly because of the lack of gas turbines operating in parallel with the steam cycle. According to a net energy analysis ${ }^{2}$ for fluidized-bed systems, the rate of delivered energy output to total primary energy input is also favorable to the AFBC system.

Environmental Control. Three major pollutants are emitted by the burning of coal in a power plant: sulfur oxides, nitrogen oxides, and particulates.

For fluidized-bed combustion systems, the use of limestone or dolomite as the bed material provides a means for removing the $\mathrm{SO}_{2}$ generated during coal combustion. Because the AFBC is operated under oxidizing conditions, complete combustion is possible, and $\mathrm{SO}_{2}$ is removed as $\mathrm{CaSO}_{4}$. Fluidized-bed systems also offer the potential for inherently low $\mathrm{NO}_{\mathbf{x}}$ emissions because of lower combustion temperatures. In most cases $\mathrm{SO}_{2}$ and $\mathrm{NO}_{\mathbf{x}}$ emissions are below the present federal standards. 2-4

The control of particulates is similar to that in conventional power plants. In general, control is accomplished by mechanical devices such as centrifugal collectors (cyclones), wet collectors, electrostatic precipitators, and baghouses. In this study, conventional cyclones and hot electrostatic precipitators were assumed as the furnace-gas cleanup equipment. Furthermore, for this energy balance study, the performance of the conversion system and environmental control system were merged.

Steam-Cycle System. The energy flow from an atmospheric fluidized-bed combustor has two major outlets: the flue-gas circuit and the water/steam circuit. The water/steam circuit generates the electricity using a steam turbine driving an electrical generator, whereas the flue-gas circuit is funneled through the environmental control equipment. 
Water is converted to steam in tubes placed inside the combustor. The thermal energy of superheated steam is converted into mechanical energy by expansion in a steam turbine, and the mechanical energy is changed to electricity by the generator. After leaving the turbine, the low-pressure steam is converted back to water in a condenser. Energy is released during condensation and absorbed by water or air at a cooling tower, and then discharged into the atmosphere. This is the conventional steam-cycle system that is used in modern coal-fired power plants.

\section{B.1.3 Énergy Balance Parameters}

l'wo types of energy flow, are included in the nct energy allalys is of a coal fuel cycle: primary energy, and operating and capital energy.

The primary energy flow diagram of a fuel cycle for the $\Lambda F B C$ from mining to busbar is shown in Fig. B.2. The nominal size of the unit chosen for study ( 747 MWe operating at a capacity factor of $65 \%$ ) requires $2.35 \times 10^{6}$ $t$ of bituminous coal per year with a heating value of $2.32 \times 10^{10} \mathrm{~J} / \mathrm{t}(10,000$ $\mathrm{Bt} u / \mathrm{lb})$; it is assumed to be strip-mined coal. After mining, preparation, and transportation losses are subtracted, the coal thermal input to the conversion system is $42.833 \times 10^{12} \mathrm{~J}$ (from $1.84 \times 10^{\mathrm{h}} \mathrm{t}$ of coul). Except for the energy loss in the conversion system, all the heat released in the combustor $(37,639$ $x 1012 \mathrm{~J}$ ) is transmitted to the steam cycle. The steam turbine generates $15,326 \times 10^{12} \mathrm{~J}$ of electric power $\left(4.25 \times 10^{9} \mathrm{kWh}\right)$.

Annual operating and capital energy requirements for the AFBC were normalized to the electric output of $15,326 \times 1012 \mathrm{~J}$; results are summarized in Table B.1. The operating and capital energy consumption for coal extraction, preparation, and transportation, and for $\mathrm{plant}$ operation and constiuction materials has been calculated using the input/output methodology and the cost estimates of appropriate materials for each economic sector.1,2

\section{B.1.4 Identification of Sensitive Data}

The primary energy efficiencies for the present study were estimated from previous analyses. It is important to review the range for each of these parameters for the identification of sensitive data. Table B.2 shows the range of available data on the efficiencies of the primary energy flow used for the system studied here. The most significant step for energy utilization 

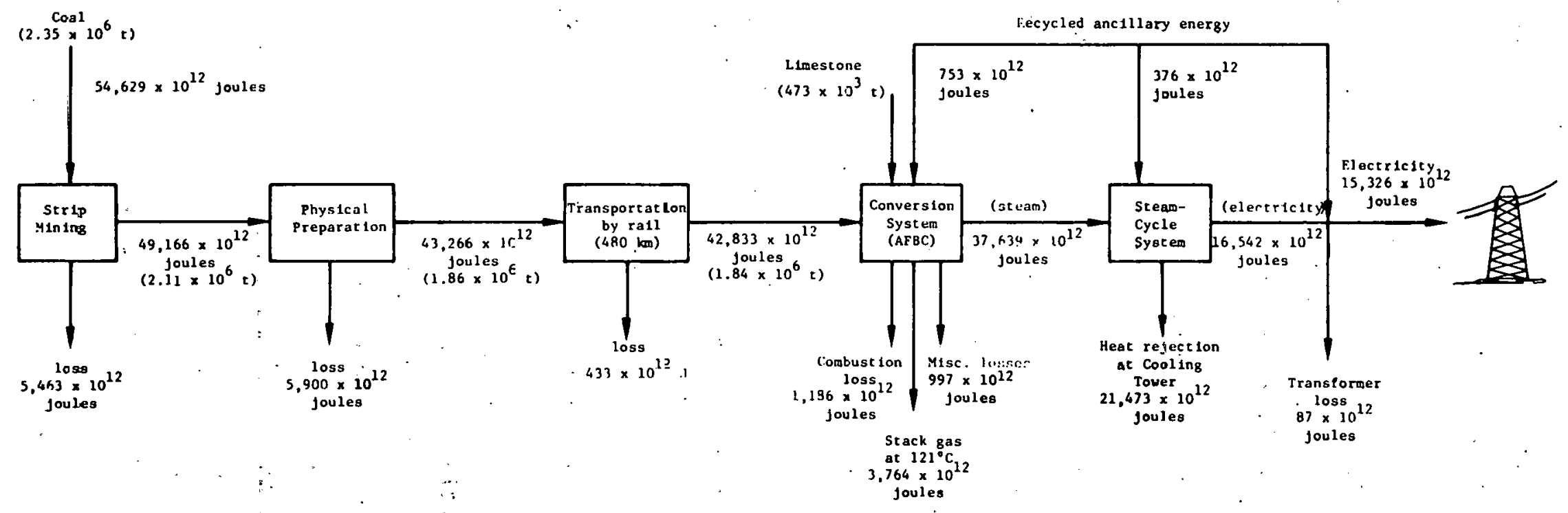

Fig. B.2. Primary Energy Flow Diagram of an AFBC Cycle 
Tabie B.1. Energy Balance Parameters for AFBC System

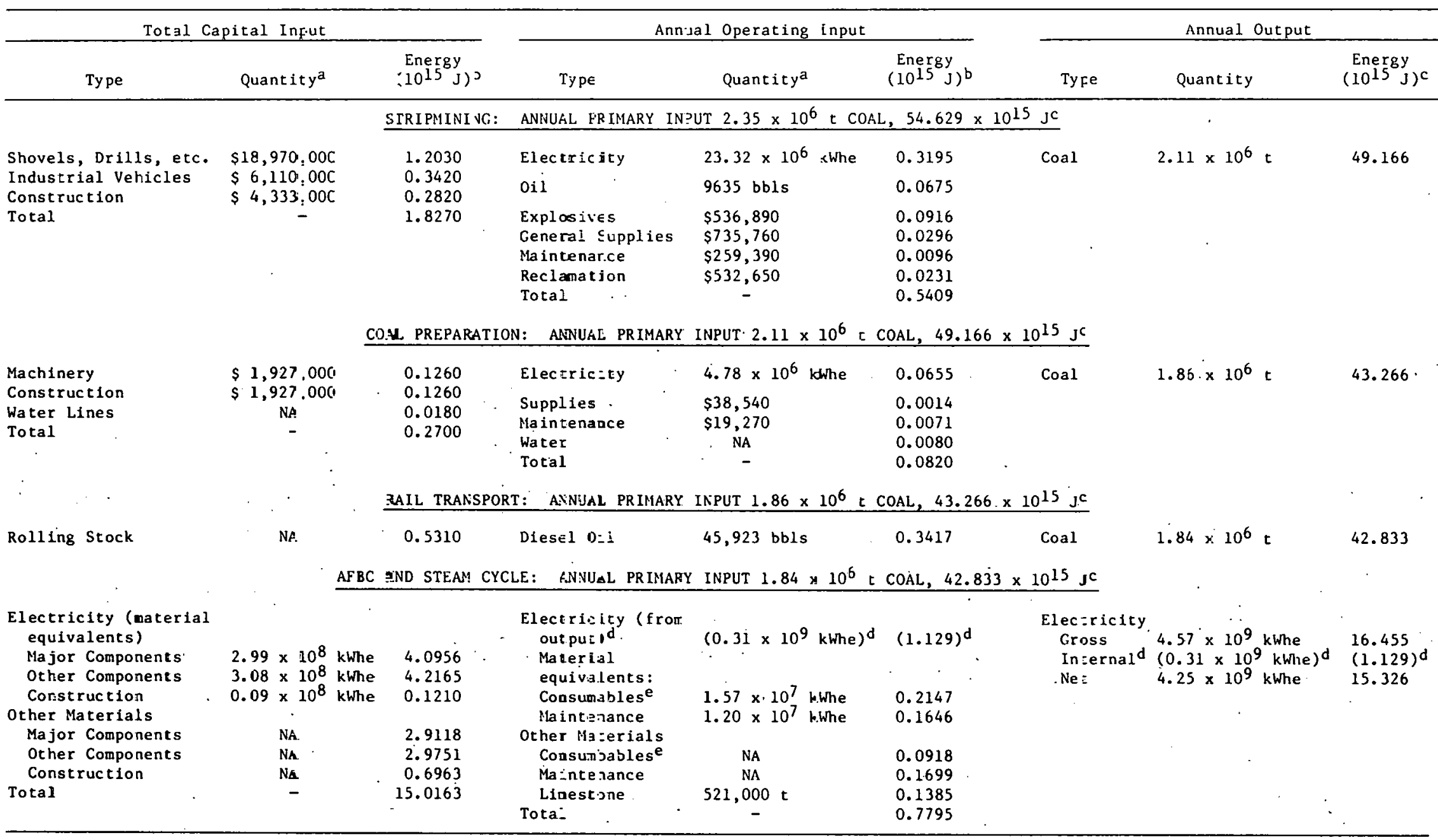

aDollar amounts in 1974 dollazs.

bCapltal and opezating energy computed by $1 / 0$ analysis as energy cost of fuels, materials, and electricity used.

cEnergy input and output.compited as heat content of fuels or joule equivalent of e-ectricity generated.

dinternal use, included in ousput total only.

ether than limestone. 
Table B.2. Energy Efficiencies for the Primary Energy Flow in the AFBC System

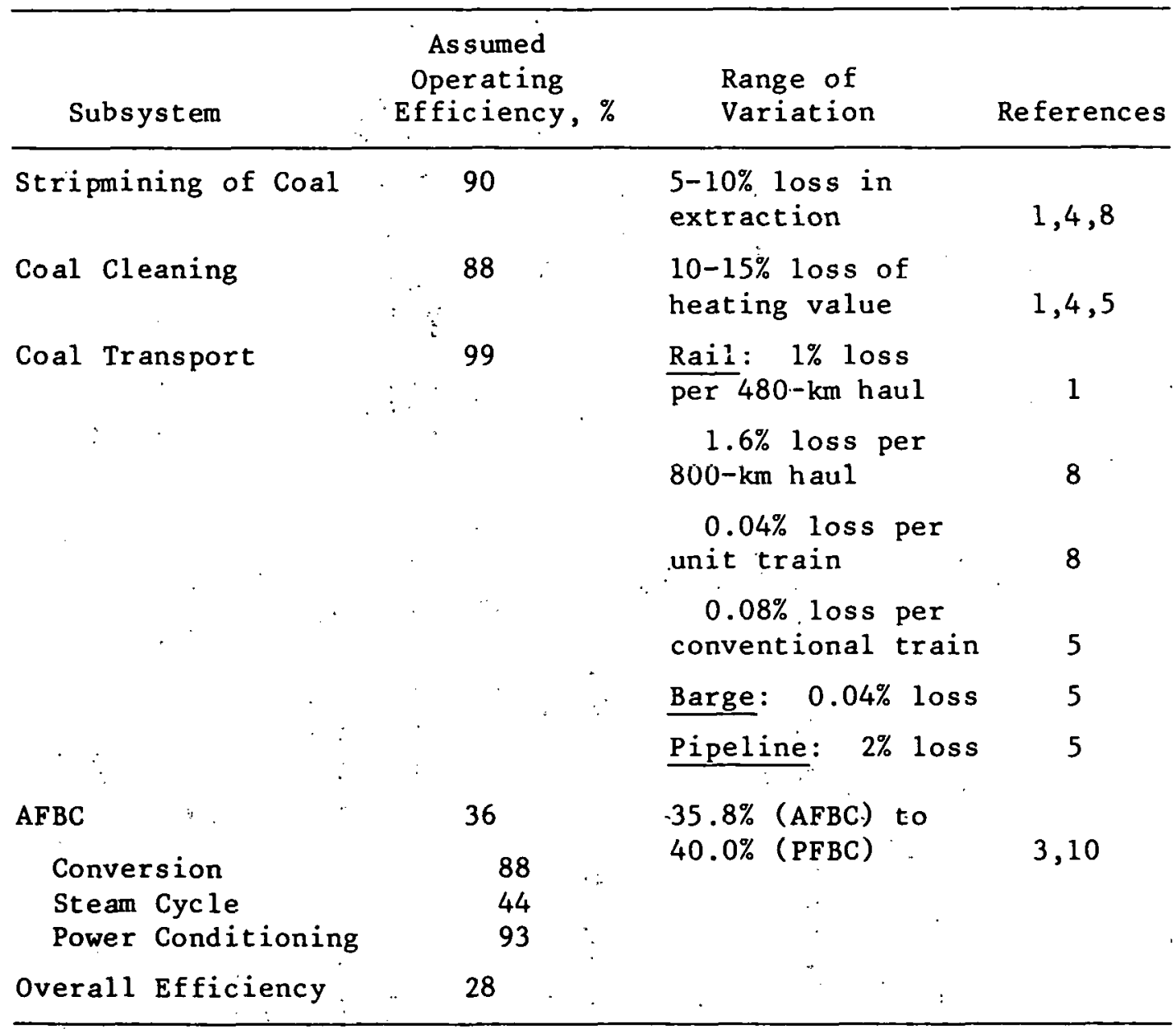

must be the AFBC system which has a $36 \%$ overall efficiency in this study. According to Refs. 3 and 7, however, there is not much room to improve the overall power plant efficiency.

Because of the lack of data, the range of operating and capital energy requirements is not shown.

\section{B.2 COAL GASIFICATION/COMBINED CYCLE (CG/CC)}

\section{B.2.1 Description of the Overall System}

The system studied is a coal-fired steam cycle using a Westinghouse gas-turbine/steam-turbine, combined-cycle system integrated with a low-Btu fluidized-bed gasifier.: The analysis was based on a system required to 
deliver electricity to a utility grid at a 741.5-MWe output, generating 15,203 $\times 10^{12} \mathrm{~J} / \mathrm{yr}\left(4.222 \times 10^{9} \mathrm{kWh} / \mathrm{yr}\right)$ of electricity with a plant capacity factor of $65 \%$.

Figure B.3 shows a simplified flow diagram of a coal fuel cycle for the Westinghouse integrated gasifier and combined cycle system (CG/CC). In addition to mining, preparation, and transportation of the coel, separate unit processes in the $C G / C C$ system were grouped into the following subsystems to allow separate energy balances: the gasifier/cleanup system; and the combined cycle, consisting of the gas-turbine system, heat recovery system, and steamcycle system. Energy balances for each subsystem were calrulater on the baoio of available references $1,9,3$ and normalized to the clcctrical uulpul of 13,203 $x 10^{12} \mathrm{~J} / \mathrm{yr}$. The construction period and 1 ife of the power plant were assumed to be 5 yr and 30 yr respectively. ${ }^{9}$

\section{B.2.2 System Elements}

The mining, preparation, and transport of coal assumed for the $\mathrm{CG} / \mathrm{CC}$ system are identical to the processes described in Sec. B.1.2. The other system elements, conversion (gasifier/cleanup) and the combined cycle system, are described briefly belnw.

Gasifier/Cleanup system. The conversion system is itself divided into other subsystems: cnal and dolomite handilig, gasificarton, and hot gas cleanup. A pressurized fluidized-ber gasifier with a hot gas cleanup system was analyzed.

The Westinghouse fluidized-bed gagificr is made up of two stages, one a $870^{\circ} \mathrm{C}\left(1666^{\circ} \mathrm{F}\right)$ desulfurizer/devolatizer bed; the other a $1093^{\circ} \mathrm{C}\left(2000^{\circ} \mathrm{F}\right)$ agglomerating gasifier bed. 9 Dry, crushed coal from the coal handling system is injected into the gas stream from the gasifier and devolatilized in the $870^{\circ} \mathrm{C}$ bed. Desulfurization is accomplished by injecting dolomite into the bed. The char and fines from this bed are gasified in the $1093^{\circ} \mathrm{C}$ bed in the presence of air and steam; the gas leaving the gasifier is recycled to fluidize the desulfurizer/devolatilizer bed. This gasification process must be able to operate at a temperature high enough to avoid tars in the resultant flue gas, but low enough to avoid volatilizing and carrying over alkalimetals. The low-Btu gas leaving the gasifier vessels passes through a three- 


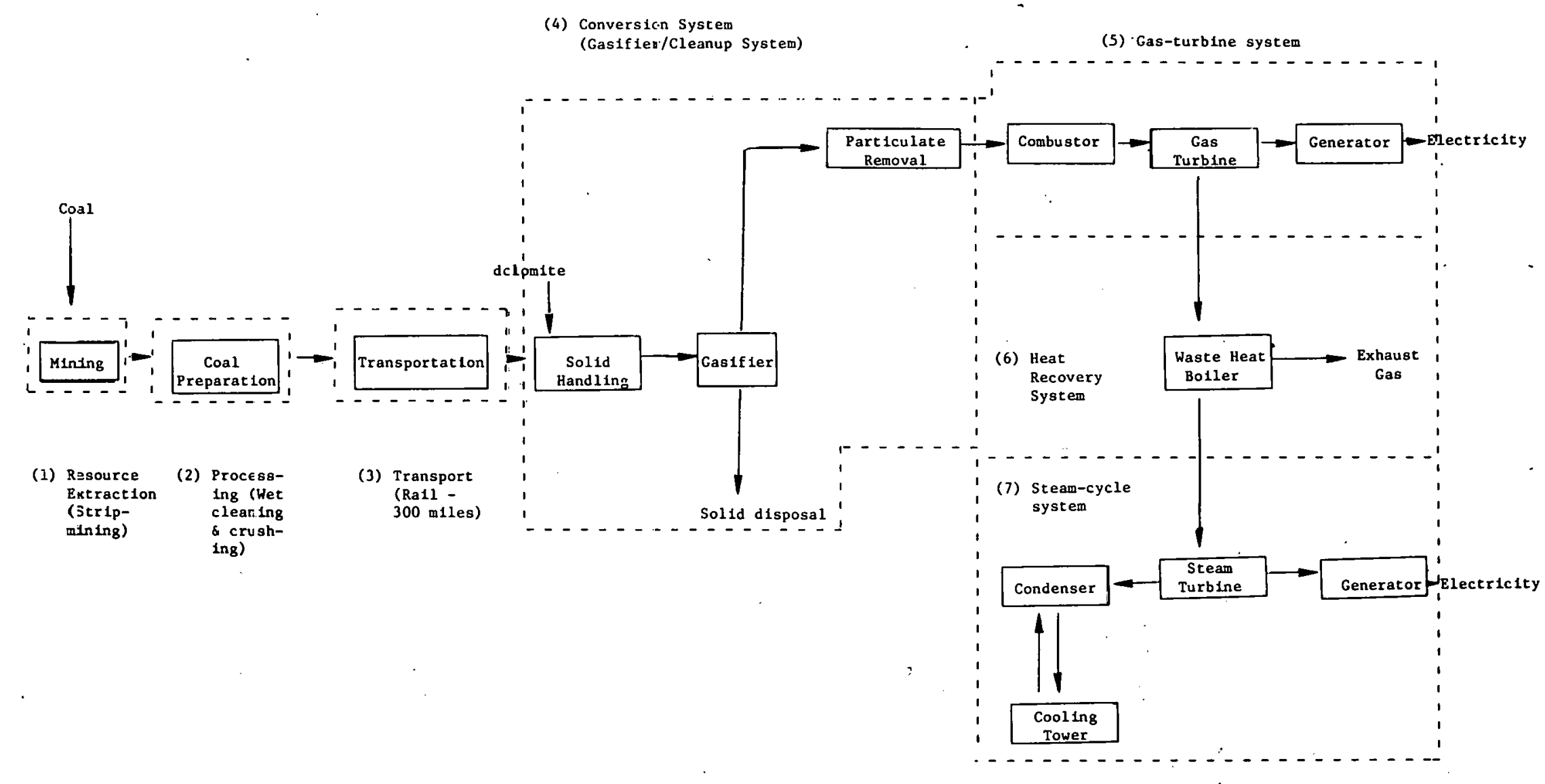

Fig. B.3. Simplified Flow Diagram of Low-Btu CG/CC System 
stage particle cleanup system consisting of a cyclone, a multiclone unit, and a granular bed filter.

The $\mathrm{plant}$ :requires $66.9 .5 \mathrm{~kg} / \mathrm{s}(265.7$ tons $/ \mathrm{hr})$ of coal and $24.86 \mathrm{~kg} / \mathrm{s}$ (98.6 tons/hr) of dolomite as inputs. 9 It emits $0.3096 \mathrm{~g}$ of $\mathrm{sO}_{2}, 0.2795 \mathrm{~g}$ of $\mathrm{NO}_{\mathrm{x}}$, and $0.00602 \mathrm{~g}$ of particulates per megajoule of input coal energy (respectively $0.91,0.65$, and $0.0141 \mathrm{~b} / 10^{6}$ Btu of input).9. These emissions are respectively, $76 \%, 93 \%$, and $14 \%$ of the relevant EPA emission limits. 9 The plant also discharges $24.22 \mathrm{~kg} / \mathrm{s}(96.12$ tons $/ \mathrm{hr}$ ) of solid wastes (așh and spent sorbent), which are disposed of in an on-site 1 and fil1. 9 ,

Three basic low-Br" gasification proccases are available: flxed or moving bed (used by Lurgi, McDowel1-Wellman; and.G.E.); filuidized bed (used by IGT, Westinghouse, and BCR); and entrained flow. (used by Foster Wheeler and Texaco) $.7,9,10$

The G.E. fixed-bed: process and the Westinghouse fluidized-bed process were chosen for this study because good data were available for both.3,9 After results for the two systems were compared, the "Westinghouse system was finally selected for analysis because it had better overall efficiency: the G.E. design for the integrated gasifier/combined cycle has an overall efficiency of $39.6 \%$, whereas the Westinghouse design has an overall efficiency of $46.8 \% .3$ The difference in efficiency is attributable to the differing thermodynamic efficiencies of gas and steam turbines and to differences between the two gasifier/cleanup systems: in the G.E." cleanup oyotem, "a large porlion of the sensible heat is lost when the gas is water-washed to remove tars, oils, and phenols, and is desulfurized, whereas the Westinghouse design uocs in-bed desulfurization and hot-gas particulate cleanup, with the result that little of the sensible heat of the gas is lost. 3

Combiued=Cycle system. The combined-cycle system consists of a gasturbine system, a heat recovery system, and a steam-cycle system. The net plant electrical output in this study is $15,203 \times 1012 \mathrm{~J} / \mathrm{yr}$ with a $65 \%$ plant capacity. About $66 \%$ of the net power is derived from the gas-turbine generators, and the remainder is from the steam-turbine generator.

A part of the gas turbine!'s compressor air is recycled and passed through a coupled, fluidized-bed gasifier with three stages of hot gas cleanup. The resultant low-Btu fuel gas is burned in the gas-turbine combustor. The products of combustion expand through the gas turbine and flow upward 
through a heat-recovery steam generator, and then to the stack. Steam generated in the heat-recovery boiler is expanded through a steam turbine with an abbreviated feedwater heater system. Heat rejected from the steam turbine into the condenser is discharged to the atmosphere by means of mechanicaldraft evaporative cooling tower? 9

\section{B.2.3 Energy Balance Parameters}

Figure B.4 shows the primary energy flow diagram of the CG/CC system analyzed. The $741.5-\mathrm{MWe}$ unit, operating at a $65 \% \mathrm{plant}$ capacity factor, requires $1.78 \times 10^{6} t$ of bituminous coal annually, with a heating value of $2.32 \times 1010 \mathrm{~J} / \mathrm{t}(10,000 \mathrm{Btu} / 1 \mathrm{~b})$. Strip-mined coal is assumed; after mining, preparation, and transportation losses are deducted, the coal thermal input to the conversion system is $32,494 \times 10^{12} \mathrm{~J}$ (from $1.40 \times 10^{6} \mathrm{t}$ of coal). Most of the heat released in the combustor is transmitted to the gas turbine, which produces $10,503 \times 10^{12} \mathrm{~J}\left(2.92 \times 10^{9} \mathrm{kWh}\right)$ of electric power. After leaving the gas-turbine system, the combustion products move to heat-recovery boilers. The heat-recovery system delivers steam to the steam turbine, which generates $5,512 \times 10^{12} \mathrm{~J}\left(1.53 \times 10^{9}, \mathrm{kWh}\right)$ of electricity. After subtraction of recycled ancillary energy and transformer losses, a balance of $15,203 \times 10^{12} \mathrm{~J}(4.22 \times$ $10^{9} \mathrm{kWh}$ ) of electric power is produced by this system.

Operating and capital energy requirements for the CG/CC system were normalized to the electric output of $15,203 \times 10^{12} \mathrm{~J}$; they are summarized in Table B.3. Annual operating and capital energy consumption for coal extraction, preparation, and transportation were calculated by using an input/output analysis and the cost estimates of appropriate materials for each economic sector. 1

\section{B.2.4 Identification of Sensitive Data}

Because the energy efficiencies for this study were estimated from existing data, it is necessary to review the range of each of those parameters to identify sensitive data. Table B.4 shows all the available efficiency data for the primary energy flow used in the system studied. The most significantly limiting step is the gasifier/combined-cycle system, with $46.8 \%$ overall efficiency. According to Refs. 11 and 15, it seems that this efficiency is not likely to improve significantly in the near future. 


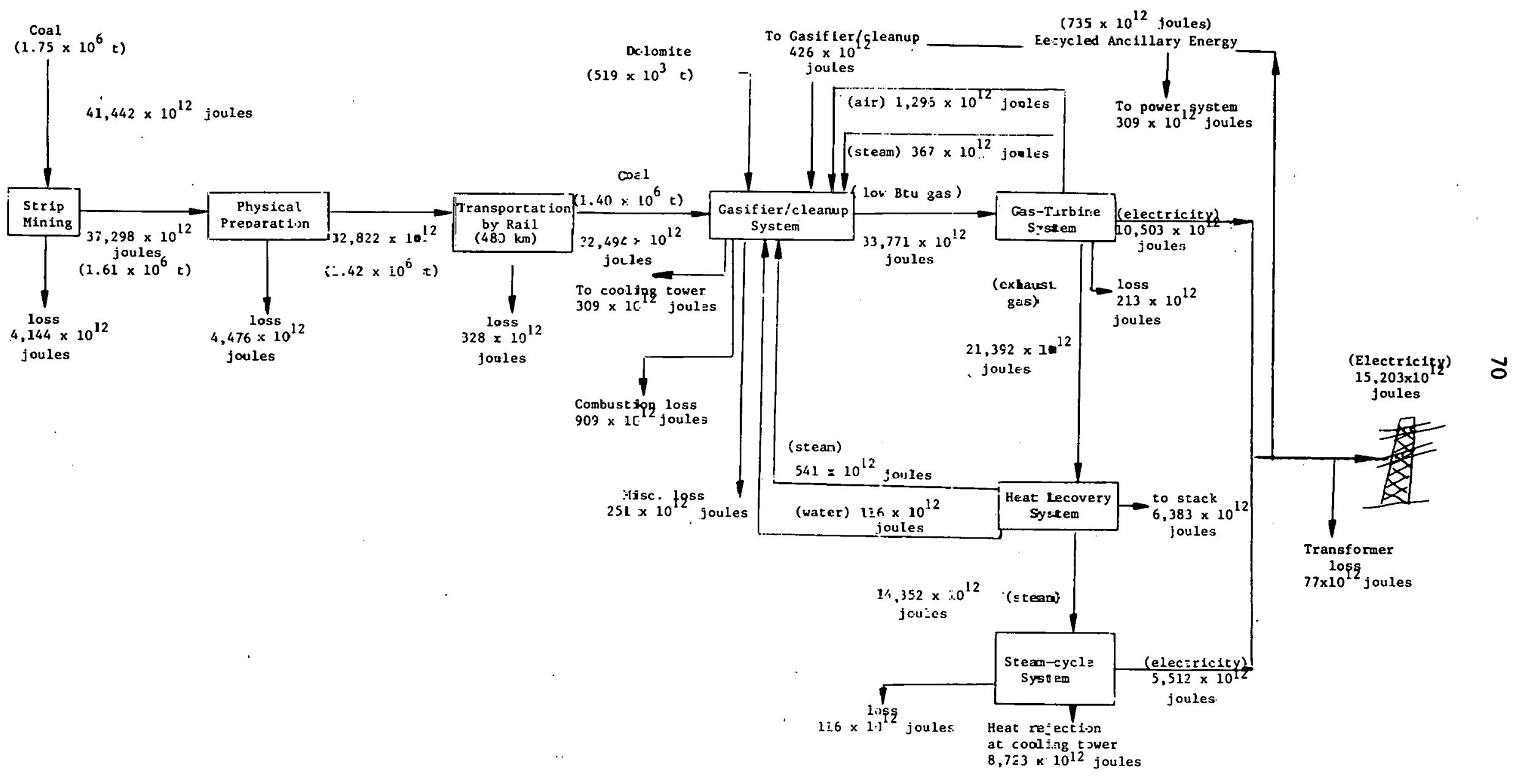

Eig. B.4. Prinary Energy Flow in a Low-Btu CG/CC Syiszem 
Table B.3. Energy Balance for CG/CC System

\begin{tabular}{|c|c|c|c|c|c|c|c|c|c|c|c|c|}
\hline \multirow[b]{2}{*}{$\begin{array}{l}\text { System } \\
\text { Element }\end{array}$} & \multicolumn{3}{|c|}{ AnnuEl Primary Input } & \multicolumn{3}{|c|}{ Toral Capica! Inpurs } & \multicolumn{3}{|c|}{ Annual Operating Inpurs ${ }^{b}$} & \multicolumn{3}{|c|}{ Annual Output } \\
\hline & Type & Quantity & $\begin{array}{l}\text { Energy } \\
\left.\left(10^{i}\right)_{J}\right)\end{array}$ & Type & Quantity & $\begin{array}{l}\text { Energyti } \\
\left(10^{1}{ }^{6}\right)\end{array}$ & Type & Quantity & $\begin{array}{l}\text { Energy" } \\
\left.\left(10^{1}\right)_{3}\right)\end{array}$ & Type & Quancity & $\begin{array}{l}\text { Energy } \\
\left(10^{1}{ }^{a}\right. \\
J)\end{array}$ \\
\hline Stripaining & Cool & $1.78 \times 10^{6} \mathrm{t}$ & 41.442 & $\begin{array}{l}\text { Shove!s, drills, etc. } \\
\text { Indus:rial vehicles } \\
\text { construction } \\
\text { Total }\end{array}$ & $\begin{array}{r}\$ 14,385,000 \\
\$ 4,633,000 \\
\$ 3,286,000\end{array}$ & $\begin{array}{l}0.9120 \\
0.2580 \\
0.2130 \\
1.3830\end{array}$ & $\begin{array}{l}\text { Electricity } \\
\text { oit } \\
\text { Explosives } \\
\text { Gen. Suppties } \\
\text { Maint enance } \\
\text { Reclamation } \\
\text { Total }\end{array}$ & $\begin{array}{c}17.68 \times 10^{6} \mathrm{kwhe} \\
7307 \mathrm{b01 \textrm {s }} \\
\$ 197,000 \\
\$ 558,000 \\
\$ 407,000 \\
\$ 404,000 \\
-\end{array}$ & $\begin{array}{l}0.2422 \\
0.0512 \\
0.0694 \\
0.0225 \\
0.0073 \\
0.0175 \\
0.4101\end{array}$ & Coal & $1.61 \times 10^{6} \mathrm{c}$ & 37.298 \\
\hline Coal Preparation & Coal & $1.61 \times 10^{6} \mathrm{t}$ & 37.298 & $\begin{array}{l}\text { Machiaery } \\
\text { Construction } \\
\text { Hater Line } \\
\text { Total }\end{array}$ & $\begin{array}{c}\$ 1,461,000 \\
\$ 1,461,000 \\
N A \\
-\end{array}$ & $\begin{array}{l}0.0960 \\
0.0960 \\
0.0150 \\
0.2070\end{array}$ & $\begin{array}{l}\text { Electricity } \\
\text { Suplies } \\
\text { Maintenance } \\
\text { Water } \\
\text { Total }\end{array}$ & $\begin{array}{c}3.62 \times 10^{6} \mathrm{kWhe} \\
\$ 29,000 \\
\$ 146,000 \\
\text { NA } \\
-\end{array}$ & $\begin{array}{l}0.0496 \\
0.0010 \\
0.0054 \\
0.0061 \\
0.0621\end{array}$ & Coal & $1.42 \times 10^{6} \mathrm{c}$ & $32.82 \hat{\epsilon}$ \\
\hline Eail Transport & Coal & $1.42 \times 10^{6} t$ & 32.822 & Rollit.g Stock & NA & 0.4020 & Diesel oil & $34,828 \mathrm{bbls}$ & 0.2592 & Coal & $1.40 \times 10^{6} \mathrm{t}$ & 32.494 \\
\hline Casifier'Cleanup & Coal & $1.40 \times 10^{6} \mathrm{t}$ & 32.494 & -.....----(Included & below)---.-. & -........ & $\begin{array}{l}\text { Dolomite } \\
\text { Gas Turbine: Air } \\
\text { Steam } \\
\text { Boiler: Steam } \\
\text { Water }\end{array}$ & $\begin{array}{c}518,989 c \\
- \\
- \\
- \\
-\end{array}$ & $\begin{array}{l}0.1519 \\
(1.2960)^{d} \\
(0.3670)^{d} \\
(0.5410)^{d} \\
(0.1160)^{d}\end{array}$ & Low Btu Gas & $+\ldots$ & $\begin{array}{l}33.771 \\
\therefore \\
\therefore\end{array}$ \\
\hline Gas Iurbine & Lov Bcu Gas & : & 33.771 & - Included & selow) & 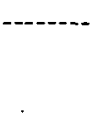 & Internal Elec. & - & $(0.4260)^{d}$ & $\begin{array}{l}\text { Internal Use: Air } \\
\text { Stean co boiler. } \\
\text { Exhaust to boiler } \\
\text { Electricity }\end{array}$ & $\begin{array}{c}- \\
- \\
2.92 \times 10^{9} \mathrm{kWhe}\end{array}$ & $\begin{array}{r}1.296 \\
0.367 \\
21.392 \\
10.503\end{array}$ \\
\hline Heat Recavery & Exhaust Gas & - & 21.392 & --n----CIncluded & selout-.-.-- & 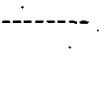 & - & - & - & $\begin{array}{l}\text { Steam co Gasifier } \\
\text { To Turbine } \\
\text { Water to Gasifiér. }\end{array}$ & $=$ & $\begin{array}{r}0.541 \\
14.352 \\
0.116\end{array}$ \\
\hline Sxean Cycle & St e am & - & 14.352 & - - & ivelou)------ & 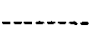 & - & - & - & Electricity & $1.53 \times 10^{9} \mathrm{kwhe}$ & 5.512 \\
\hline Power Trans former & Electricicy & $4.45 \times 10^{9} \mathrm{kthe}$ & 16.015 & $\cdots---\infty$ Included & below)--..... & (n-......... & - & - & - & $\begin{array}{l}\text { Electricity } \\
\text { Gross } \\
\text { To Gasifier } \\
\text { To Generator } \\
\text { Net }\end{array}$ & $\begin{array}{l}4.43 \times 10^{9} \mathrm{kWhe} \\
0.12 \times 10^{9} \mathrm{kWhe} \\
0.09 \times 10^{9} \mathrm{kWhe} \\
4.22 \times 10^{9} \mathrm{kthe}\end{array}$ & $\begin{array}{r}15.938 \\
0.426 \\
0.309 \\
15.203\end{array}$ \\
\hline Treal Pouer Plant & $=$ & - & - & $\begin{array}{l}\text { Major Components } \\
\text { Other Components } \\
\text { Total }\end{array}$ & $\begin{array}{l}=217,100,000 \\
=105,000,000\end{array}$ & $\begin{array}{r}9.1940 \\
4.4470 \\
13.6410\end{array}$ & 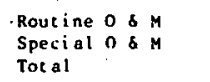 & $\begin{array}{l}\$ 4,350,000 \\
\$ 1,385,000\end{array}$ & $\begin{array}{l}0.1570 \\
0.0490 \\
0.3579\end{array}$ & & 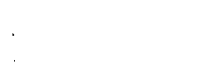 & \\
\hline
\end{tabular}

anergy inpul and output computed as heat content of fuels or jcule equivalent of electrifity generated.

bollar amounts in 1974 dollars.

ciapital and operating energy computed by $I / 0$ analysis as energy cost af fuels, materials; and electricity used.

dinternal use: included in output total only. 
Table B.4. Energy Efficiencies for the Primary

Energy Flow in the CG/CC System

\begin{tabular}{|c|c|c|c|c|}
\hline Subsystem & $\begin{array}{c}\text { Assumed } \\
\text { Operating } \\
\text { Efficiency, }\end{array}$ & $\%$ & $\begin{array}{l}\text { Range of } \\
\text { Variation }\end{array}$ & References \\
\hline Stripmining of Coal & 90 & & $\begin{array}{l}5-10 \% \text { loss in } \\
\text { extraction }\end{array}$ & $1,4,8$ \\
\hline Coal Cleaning & 88 & & $\begin{array}{l}10-15 \% \text { loss of } \\
\text { heating value }\end{array}$ & $1,4,5$ \\
\hline \multirow[t]{6}{*}{ Coạl Transport } & 99 & $\because$ & $\begin{array}{l}\text { Rail }: \quad 1 \% \text { loss } \\
\text { per } 480-\mathrm{km} \text { haul }\end{array}$ & 1 \\
\hline & $\cdot$ & & $\begin{array}{l}1.6 \% \text { loss per. } \\
800-\mathrm{km} \text { haul }\end{array}$ & 8 \\
\hline & & & $\begin{array}{l}0.04 \% \text { loss per } \\
\text { unit train }\end{array}$ & 8 \\
\hline & . & & $\begin{array}{l}0.08 \% \text { loss per } \\
\text { conventional train }\end{array}$ & 5 \\
\hline & $\ddots$ & & Barge: $0.04 \%$ loss & 5 \\
\hline & & & Pipeline: $2 \%$ loss & 5 \\
\hline $\mathrm{CG} / \mathrm{CC}$ & .46 .8 & & $\begin{array}{l}39.6 \% \text { (G.E., fixed- } \\
\text { bed) to } 42.2 \% \\
\text { (IGT, fluidized- } \\
\text { bed) }\end{array}$ & 3,10 \\
\hline Overall Efficiency & 36.7 & & & \\
\hline
\end{tabular}


REFERENCES TO APPENDIX B

1. Frabetti, A., et al., A Study to Develop Energy Estimates of Merit for Selected Fuel Technologies, Development Sciences, Inc., East Sandwich, Mass. (Sept. 23, 1975).

2. Perry, A.M., et al., Net Energy Analysis of Five Energy Systems, Institute for Energy Analysis, Oak Ridge Associated Universities, ORAU/IEA(R)-N-12 (Sept . 1977).

3. Evaluation of Phase 2 Conceptual Designs and Implementation Assessment Resulting from the Energy Conversion Altermatives Study (ECAS), NASA Lewis Research Center, Cleveland, Ohio (April 1977).

4. Ferrel1, G., Energy Utilization and Environmental Control Technologies in the Coal-Electric Cycle, Lawrence Berkeley Laboratory Report LBL-6334, Berkeley, Calif. (Oct. 1977).

5. Cirillo, R.R., et al., An Evaluation of Regional Trends in Power Plant Siting and Energy Transport, Argonne National Laboratory Report ANL/AA-9, Argonne, I11. (July 1977).

6. Yaverbraum, L., Fluidized-Bed Combustion of Coal and Waste Materials, Noyes Data Corporation, Park Ridge, N.J. (1977).

7. Cirillo, R.R., unpublished information.

8. Vogenthaler, Thomas, et al., Net Energy Analyses: An Energy Balance Study of Fossil Fuel Resources, Colorado Energy Research Institute, Golden, Col. (April 1976).

9. Beecher, D.T., et al., Energy Conversion AZternatives Study (ECAS) Westinghouse Phase II Final Report; Summary and Combined Gas-Steam Turbine Plant with an Integrated Low-Btu Gasifier. Westinghouse Electric Corp. Research Laboratories, Pittsburgh, Pa. (Nov. 1, 1976).

10. Reddy, N., Commercialization of Coal-Based Combined Cycle Plants, presented at the 71 st Annual Meeting of the APCA, Houston, Tex. (June 1978). 


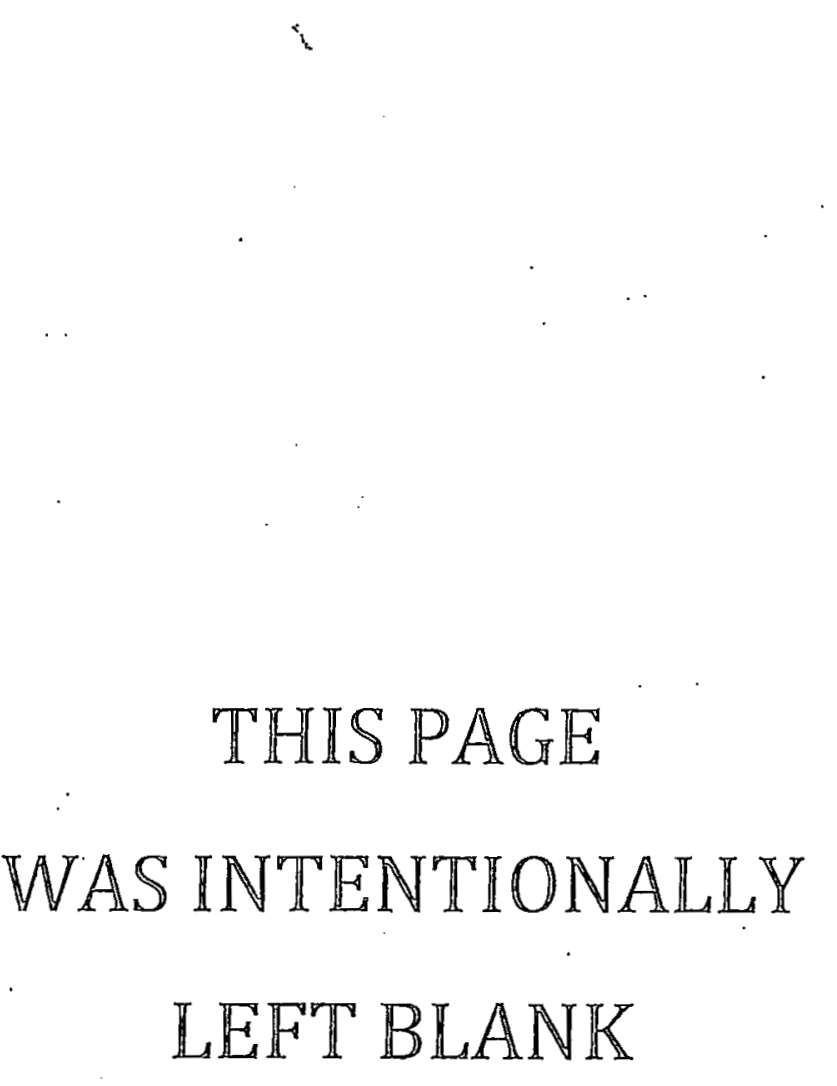




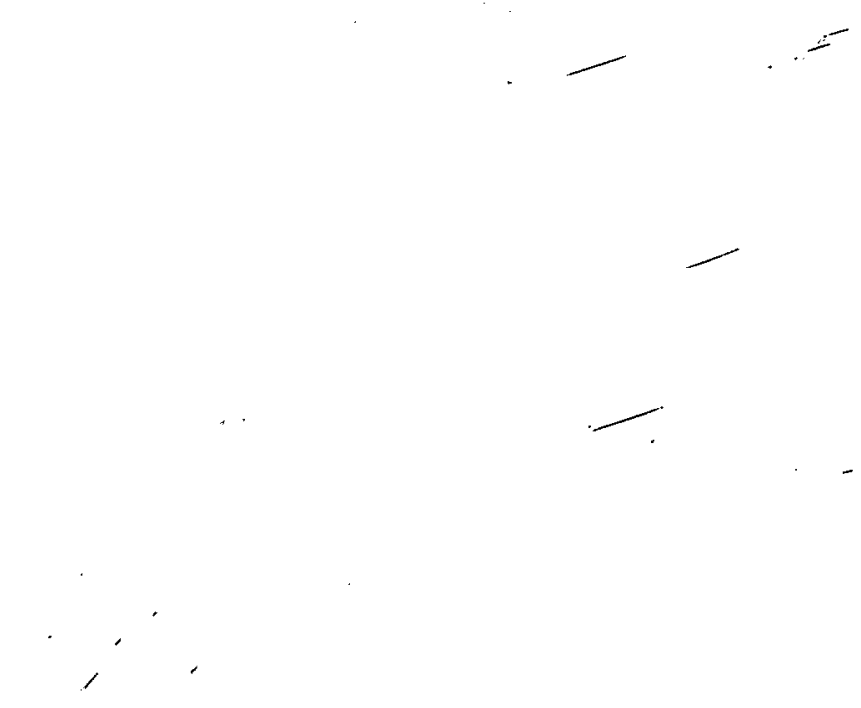

APPENDIX C

NUCLEAR FUEL CYCLE 
THIS PAGE

\section{WAS INTENTIONALLY LEFT BLANK}




\section{C.1 DESCRIPTION OF THE OVERALL SYSTEM}

This appendix describes the direct energy, process energy, and construction energy inputs required in each stage of the nuclear fuel cycle. These requirements, which include the energy use associated with mining of the ore and transport and storage of the wastes, áre those necessary to support the annual operation of a 1000-MWe light water reactor (LWR). Most of the data were developed by the Institute for Energy Analysis (IEA) of Oak Ridge Associated Universities ${ }^{1}$ and adjusted according to the assumptions used by the Energy Research and Development Administration. 2

The use of conventional uranium ores $\left(0.208 \% \mathrm{U}_{3} \mathrm{O}_{8}\right.$, of which $0.71 \%$ is $\mathrm{U}^{235}$ ) with an enrichment tails assay of $0.2 \%$ is assumed. Reprocessing of wastes for recovery of unused uranium and plutonium is not considered. The reactor is assumed to have a service life of 30 years, during which it produces an average of $19,240 \times 10^{12} \mathrm{~J} / \mathrm{yr}\left(5.343 \times 10^{9} \mathrm{kWh} / \mathrm{yr}\right)$ at a capacity factor of $61 \%$. Figure C.1 shows a simplified schematic diagram of the nuclear fuel cycle considered.

\section{C.2 SYSTEM ELEMENTS}

\section{C.2.1 Mining}

Most of the uranium produced domestically is recovered from high-grade sandstone deposits in the western United States. The ores found in this region contain $0.1 \%$ to $0.5 \%$ uranium. Both open pit and underground mining methods are utilized; the choice depends on the depth and nature of the rock strata of the overburden covering the ore.

Current mining practices are mechanized and highly efficient operations that extract almost all of the uranium. Electric and fuel purchase requirements have been determined by the Institute for Energy Analysis (IEA) ${ }^{1}$ from

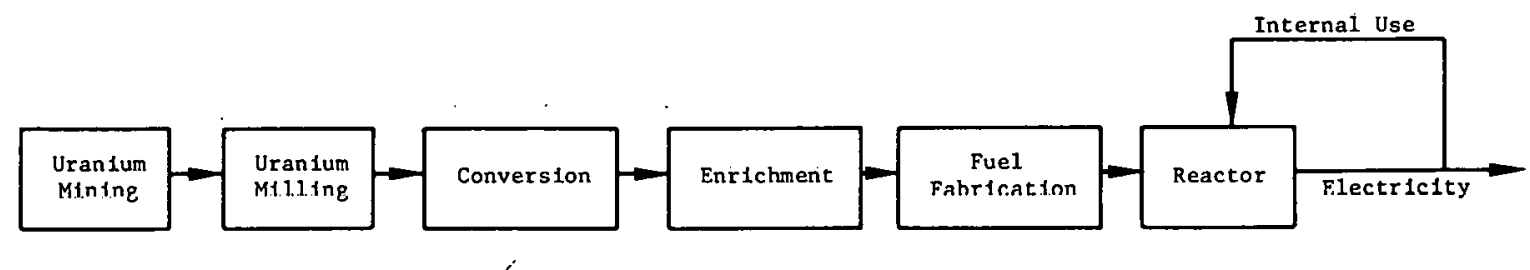

Fig. C.1. Simplified Flów Diagram of Nuclear Fuel Cycle 
1973 Bureau of Mines (BOM) survey data. The annual direct electrical purchase that is required to support a 1000-MWe light water reactor is $1,586 \mathrm{MWh}$. Petroleum products needed for mine operation are divided into categories of heavy fuel oil, diesel and light fuel oil, gasoline, and other petroleum products. These fuel quantities and the energy content required for the mining of $65,950 \mathrm{t}$ of ore ( $137.16 \mathrm{t}$ uranium) are listed in Table C.1.

One common recovery technique is room and pillar mining, in which material is tunnel-bored and transported to the surface where it is crushed. Equipment used in underground mining usually includes drills, boring machinery, loaders, and explosives. Open-pit mining generally is done by tractors with rippers, scrapers, tractor pushers, drill-powered shnvels, and large truck fleets. 3 Beneficiation of the ore before shipment to the mill is relatively uncommon at uranium mines.

The energy content of the process materials was estimated by IEA as $30.6 \times 10^{12} \mathrm{~J}$. Explosives are the largest class in the process materials requirement; their value was adjusted to reflect the 1974 ratio of surface to underground mining (59\% of uranium surface-mined and $41 \%$ deep-mined); however, these percentages vary annually.

The construction energy requirements for the mining operation were developed by amortizing the costs over an expected 10-yr mine lifetime.

Table C.1. Uranium Mining - Direct Energy Requirementsa

\begin{tabular}{|c|c|c|c|c|}
\hline Energy & $\begin{array}{l}\text { Quantity } \\
\text { (per yr) }\end{array}$ & $\begin{array}{c}\text { Energy } \\
\left(10^{9} \mathrm{~J} / \mathrm{m}^{3}\right)\end{array}$ & $\begin{array}{l}\text { Elec- } \\
\text { tricity } \\
\text { (MWh/yr) }\end{array}$ & $\begin{array}{l}\text { Energy } \\
\left(10^{12} \mathrm{~J} / \mathrm{yr}\right)\end{array}$ \\
\hline Electricity & $1,586 \mathrm{MWh}$ & - & 1,586 & - \\
\hline Heavy Diesel Fuel & $25.1 \mathrm{~m}^{3}$ & 41.7 & - & 1.0 \\
\hline Diesel \& Light Fuel & $789.9 \mathrm{~m}^{3}$ & 38.7 & - & 30.6 \\
\hline Gasoline & $46.7 \mathrm{~m}^{3}$ & 34.8 & - & 1.6 \\
\hline Other Petroleum & $38.2 \mathrm{~m}^{3}$ & 40.3 & - & 1.5 \\
\hline Natural Gas & $20,051 \mathrm{~m}^{3}$ & 0.0392 & - & 0.8 \\
\hline Other Energy & $1 \mathrm{MWh}$ & - & 1 & - \\
\hline Total & - & - & 1,587 & 35.5 \\
\hline $\begin{array}{l}\text { Per Metric Ton } \\
\text { of Uranium }\end{array}$ & - & - & 11.62 & 0.26 \\
\hline
\end{tabular}

${ }^{a}$ Quantity adjusted to show the amount needed to support a 1000-MWe LWR for each year of service using conventional ore containing $0.208 \% \mathrm{U}_{3} \mathrm{O}_{8}$, of which $0.71 \%$ is $\mathrm{U}^{235}$. 
These requirements, adjusted to reflect the amount needed annually for an 1000-MWe LWR, were $207 \mathrm{MWh}$ of electricity and $15.5 \times 10^{12} \mathrm{~J}$ of other fuels.

The total energy requirements for mining are listed in Table C.2; they represent about $2 \%$ of the entire nuclear fuel cycle energy requirements.

IEA did not indicate whether 1 and reclamation costs were included in the energy values presented above. However, because they derived much of the information from 1973 mining industry surveys, these values are likely to have included direct and operating energy requirements for reclamation that were in effect during that year.

This analysis did not consider any resource loss to occur during the mining operation, because strip-mining is very efficient in extracting the ore, and uranium ores left behind in deep mines are not, strictly speaking, lost. The energy content of the $137.16 \mathrm{t}$ uranium delivered to the mill site is $88,515 \times 10^{12} \mathrm{~J}$.

\section{C.2.2 Milling}

Extraction of the uranium from its ore (which contains, on the average, 51 bs $\mathrm{U}_{3} \mathrm{O}_{8}$ per ton of ore) is performed at the mill site. The milling operation comprises mechanical and chemical processing, from crushing and grinding the ore to the precipitation of yellowcake.

Ores are crushed and ground in ball-and-rod mills. The uranium is extracted from the ore by chemical leaching, using either sulfuric acid or an alkaline solution (usually sodium carbonate/sodium bicarbonate). The acid treatment is more common because most ores are low-lime types amenable to acid leach. ${ }^{3}$ Uranium in the leach solution is purified by either solvent extrac-

Table C.2. Uranium Mining - Total Energy Requirements

\begin{tabular}{lcc}
\hline Energy Requirement & $\begin{array}{r}\text { Electricity } \\
(\text { MWh/yr) }\end{array}$ & $\begin{array}{r}\text { Other Energy } \\
(1012 \mathrm{~J} / \mathrm{yr})\end{array}$ \\
\hline Direct & 1,587 & 35.5 \\
Process Materials & - & 30.6 \\
Mine Construction & 207 & 15.5 \\
Total & 1,794 & 81.6 \\
\hline
\end{tabular}


tion or ion exchange; solvent extraction is the more common process. Yellowcake, the final product, contains from $70 \%$ to $90 \% \mathrm{U}_{3} \mathrm{O}_{8}$ after it is calcined to remove the excess water.

Direct energy requirements were calculated by IEA $^{l}$ on the basis of Bureau of Mines data, which accounted for fuels and electricity purchased in 1973 for the milling of $91 \%$ of the yellowcake produced domestically. Annual electricity, fuel oil, and natural gas requirements for supporting a 1000-MWe LWR amount to $2,248 \mathrm{MWh} / \mathrm{yr}$ of electricity, $11.8 \times 10^{12} \mathrm{~J} / \mathrm{yr}$ of petroleum products, and $34.4 \times 10^{12} \mathrm{~J} / \mathrm{yr}$ of natural gas, as indicated in Table C.3. The milling operation considered in this analysis is projected to process $137.16 \mathrm{t}$ of uiallium annually in support of the LWR. The proces's is assimen to be $95 \%$ efficient in its extraction.

The energy content of the process materials was determined on the assumption of a $330,000-t / \mathrm{yr}^{\prime} \mathrm{mill}$ with a service life of ten years. Large quantities of sulfuric acid are required for the acid leach treatment: $34 \mathrm{~kg}$ $(75 \mathrm{lb})$ of acid per ton of ore processed, which results in an annual require-. ment of $2,482 \mathrm{t} \mathrm{H}_{2} \mathrm{SO}_{4}$ per 1000-MWe LWR. This amount of acid has an energy value of $7.4 \times 10^{12} \mathrm{~J} / \mathrm{yr}$. Other materials and supplies are estimated to have an energy value of $27.2 \times 10^{12} \mathrm{~J} / \mathrm{yr}$. Thesp nther supplies includc the sodium chlorate and manganese dioxide oxidants required for acid leaching. ${ }^{3}$

Amortized over the life of the plant, the capital energy needed for the mill was divided into two categories: the energy in construction materials

Table C.3. Uranium Milling - Direct. Energy Requirements

\begin{tabular}{|c|c|c|c|c|}
\hline Energy & $\begin{array}{l}\text { Quantity } \\
\text { (per yr) }\end{array}$ & $\begin{array}{c}\text { Energy } \\
\left(10^{9} \mathrm{~J} / \mathrm{m}^{3}\right)\end{array}$ & $\begin{array}{l}\text { Eloo- } \\
\text { tricity } \\
\text { (MWh/yr) }\end{array}$ & $\begin{array}{l}\text { Energy } \\
\left(10^{12} \mathrm{~J} / \mathrm{yr}\right)\end{array}$ \\
\hline Electricity & $2,248 \mathrm{MWh}$ & - & 2,248 & - \\
\hline Heavy Fuel oil & $68.3 \mathrm{~m}^{3}$ & 41.7 & - & 2.8 \\
\hline Diesel \& Light Fuel & $200.5 \mathrm{~m}^{3}$ & 38.7 & - & 7.8 \\
\hline Gasoline & $6.3 \mathrm{~m}^{3}$ & 34.8 & - & 0.2 \\
\hline Other Petroleum & $25.6 \mathrm{~m}^{3}$ & 40.3 & - & 1.0 \\
\hline Natural Gas & $877,920 \mathrm{~m}^{3}$ & 0.0392 & - & 34.4 \\
\hline Total & - & - & 2,248 & 46.2 \\
\hline $\begin{array}{l}\text { Per Metric Ton } \\
\text { of Uranium }\end{array}$ & - & - & 16.39 & 0.34 \\
\hline
\end{tabular}


and the direct energy used in construction. These amounted to 3.65 MWh of electricity, $0.9 \times 10^{12} \mathrm{~J} / \mathrm{yr}$ in fuels, and $4.5 \times 10^{12} \mathrm{~J} / \mathrm{yr}$ in material energy requirements.

Table C.4 summarizes the energy requirements of the milling operation; the total represents $2.2 \%$ of the entire energy requirement of the nuclear fuel cycle.

As indicated earlier, the milling operation was assumed $95 \%$ efficient in extracting the uranium from its ore. This 5\% 1oss represents about 6.9 $t$ of uranium and has an energy content of $4,431 \times 10^{12} \mathrm{~J}$. The remaining material represents $130.3 \mathrm{t}$ of uranium with an energy content of $84,084 \times 10^{12}$ $\mathrm{J}$. This reported efficiency is close to the milling industry average of $93.2 \%$ $\mathrm{U}_{3} \mathrm{O}_{8}$ recovery in the 16 producing mills operating in 1974.3

\section{C.2.3 Purification}

Uranium used in reactor fuel must be free of impurities capable of capturing neutrons. Thus furtier purification beyond the production of yellowcake is required. The process involves conversion of yellowcake to uranium hexafluoride $\left(\mathrm{UF}_{6}\right)$, which can be purified and enriched in the gaseous state.

Conversion of $\mathrm{U}_{3} \mathrm{O}_{8}$ to $\mathrm{UF}_{6}$ is usually a three-stage operation. In the first stage, the yellowcake feed is dissolved in nitric acid; the resulting uranium nitrate solution is heated to $550-600^{\circ} \mathrm{C}$ and decomposed to $\mathrm{UO}_{3}$, which is then reduced with hydregen or diesociated $\mathrm{NH}_{3}$ to $\mathrm{UO}_{2}$. During the second stage, the $\mathrm{UO}_{2}$ is converted to $\mathrm{UF}_{4}$ with anhydrous hydrogen fluoride at $450-650^{\circ} \mathrm{C}$ and then to crude $\mathrm{UF}_{6}$ with elemental fluorine at $350-500^{\circ} \mathrm{C}$. The third step entails the removal of impurities by fractional distillation.

Table C.4. Uranium Milling - Total Energy Requirements

\begin{tabular}{lcc}
\hline Energy Requirement & $\begin{array}{c}\text { Electricity } \\
(\text { MWh/yr })\end{array}$ & $\begin{array}{c}\text { Other Energy } \\
(1012 \mathrm{~J} / \mathrm{yr})\end{array}$ \\
\hline Direc't & 2,248 & 46.2 \\
Process Materials & - & 34.6 \\
Mill Construclion & 3.65 & 5.4 \\
Total & 2,252 & 86.2 \\
\hline
\end{tabular}


IEA analyzed the energy requirements for the process, and concluded that the direct energy used, mostly as natural gas, constituted the major part of the total energy required. The energy requirements for direct energy, process material, and plant construction are given in Table C.5 for a plant assumed to produce $9,090 \mathrm{t} / \mathrm{yr}$ of $\mathrm{UF}_{6}(6,180 \mathrm{t} / \mathrm{yr}$ of $\mathrm{U})$. These values represent an assumed plant service life of 30 years. Purification of uranium uses approximately $4 \%$ of the entire nuclear cycle energy requirements. IEA assumed $100 \%$ efficiency in the purification of $\mathrm{U}_{3} \mathrm{O}_{8}$; thus uranium enters and exits from this operation with a resource energy equivalence of $84,084 \mathrm{x}$ $10^{12} \mathrm{~J}$.

\section{C.2.4 Enrichment}

The gaseous diffusion enrichment process concentrates crude $\mathrm{UF}_{6}$ containing about $0.7 \% \mathrm{U}^{235}$ to the desired concentration of about $3 \%$. The process makes use of the different rates at which gases of differing molecular weights will diffuse through a porous barrier. The lighter $\mathrm{UF}_{6}$ molecules containing $\mathrm{U}^{235}$ diffuse through the barrier relatively faster than the heavier $\mathrm{UF}_{6}$ molecules containing $\mathrm{U}^{238}$, thereby separating the $\mathrm{UF}_{6}$ into two streams, one slightly enriched in the $U^{235}$ isotope and the other slightly depleted. The degree of separation in a single diffusion stage is low, but the effect $c$ an belamplified by repeating the process with many stages arranged in casc ades:

Table C.5. Energy Requirements of Uranium Purification

\begin{tabular}{lcc}
\hline Energy Requirement & $\begin{array}{c}\text { Elocticity } \\
\text { (MWh/yr) }\end{array}$ & $\begin{array}{c}\text { Other Entgy } \\
\left(10^{12} \mathrm{~J} / \mathrm{yr}\right)\end{array}$ \\
\hline $\begin{array}{l}\text { Direct } \\
\text { Electricity } \\
\text { Natural Gas }\end{array}$ & $1,327.76$ & - \\
$\begin{array}{l}\text { Process Materials } \\
\begin{array}{l}\text { Plant Construction } \\
\text { Construction Material } \\
\text { Direct Construction } \\
\text { Energy }\end{array}\end{array}$ & 553.78 & 169.7 \\
\begin{tabular}{l} 
Total \\
\hline
\end{tabular} & 0.78 & 0.8 \\
\hline
\end{tabular}


The quantity of feed material and of separative work units (SWU)* needed to produce reactor grade $\mathrm{U}^{235}$ depends on the $\mathrm{U}^{235}$ concentration in the feed material and in the tails. The optimum tails assay varies from $0.2 \%$ to $0.3 \% \mathrm{U}^{235}$. A higher tails assay would require a greater quantity of feed material to achieve the desired amount of enriched $\mathrm{U}^{235}$, but would reduce the processing time and energy requirement. It is estimated that increasing the tails assay from $0.2 \%$ to $0.3 \% \mathrm{U}^{235}$ would require about 70 additional tons of uranium to be processed for the first fueling of a 1000-MWe LWR. ${ }^{3}$

Energy requirements developed by IEA for the enrichment process were based on a plant capacity of $8.75 \times 10^{6} \mathrm{sWU} / \mathrm{yr}$. A conservative value of 2.81 MWhe/SWU was assumed, although this value represents the high end of the probable range ( 2.3 to $2.8 \mathrm{MWh} / \mathrm{SWU})$. Table C.6 summarizes the enrichment energy needed to support a 1000-MWe LWR requiring 104,133.3 $\mathrm{SWU} / \mathrm{yr}$.

Table C.6. Enrichment Energy Requirements

\begin{tabular}{|c|c|c|c|c|c|}
\hline \multirow[b]{2}{*}{ Energy Requirement } & \multirow[b]{2}{*}{$\begin{array}{l}\text { Electricity } \\
(\mathrm{MWh} / \mathrm{yr})\end{array}$} & \multicolumn{4}{|c|}{ Other Energy } \\
\hline & & $\begin{array}{l}\text { Material } \\
\text { Quantity } \\
\text { per year }\end{array}$ & $\begin{array}{r}\text { Ene } \\
\text { Cont } \\
\left(\mathrm{J} / \mathrm{m}^{3} \circ\right.\end{array}$ & $\begin{array}{l}\text { ergy } \\
\text { tent } \\
\text { or } \mathrm{J} / \mathrm{t} \text { ) }\end{array}$ & $\begin{array}{c}\text { Input } \\
\text { Energy } \\
\left(10^{12} \mathrm{~J} / \mathrm{yr}\right)\end{array}$ \\
\hline \multicolumn{6}{|l|}{ Diffusion Process: } \\
\hline Direct & $292,614.7$ & - & & - & - \\
\hline $\begin{array}{l}\text { Plant Fuels } \\
\text { Gasoline } \\
\text { Diesel Fuel } \\
\text { Propane } \\
\text { Coal }\end{array}$ & $\begin{array}{l}- \\
- \\
-\end{array}$ & $\begin{array}{r}11.5 \mathrm{~m}^{3} \\
10.1 \mathrm{~m}^{3} \\
1.2 \mathrm{~m}^{3} \\
1289 \mathrm{t}\end{array}$ & $\begin{array}{l}34.8 \\
38.7 \\
26.6 \\
27.9\end{array}$ & $\begin{array}{l}\times 10^{9} \\
\times 10^{9} \\
\times 10^{9} \\
\times 10^{9}\end{array}$ & $\begin{array}{l}0.4 \\
0.4 \\
0.03 \\
36.0\end{array}$ \\
\hline Process Materials & 603.97 & - & & - & 15.1 \\
\hline \multicolumn{6}{|l|}{ Construction: } \\
\hline $\begin{array}{l}\text { Direct } \\
\text { Materials }\end{array}$ & $\begin{aligned} & 31.24 \\
& 770.6\end{aligned}$ & - & & - & $\begin{array}{r}7.7 \\
28.0\end{array}$ \\
\hline Total & $294,020.51$ & - & & - & 87.6 \\
\hline Energy/swU & 2.82 & - & & - & $0.84 \times 10^{-3}$ \\
\hline
\end{tabular}

$a_{A}$ 30-yr plant life is assumed.

* SWU, separative work unit; is a measure of the energy required to perform the separation of uranium isotopes into two streams. 
The enrichment process involves large capital expenditures and consumes enormous amounts of electric power, with much of the power being used for recompression of the gas before each diffusion stage. Enrichment accounts for about $71 \%$ of the total energy input required for the nuclear fuel cycle, and more than $97 \%$ of the total electrical input required. Energy requirements for operation and construction are small compared with the direct energy inputs.

An enrichment operation converting $0.71 \% \quad U^{235}$ to $3.0 \% \quad U^{235}$ will lose $28.17 \%$ of the $\mathrm{U}^{235}$ input. This amounts to $36.71 \mathrm{t}$ of $\mathrm{U}$ with an energy equivalence of $23,685 \times 10^{12} \mathrm{~J} / \mathrm{yr}$. The output from this operation is $22.77 \mathrm{t}$ of enriched uranium, representing an energy equivalence of $60,515 \times 10^{12} \mathrm{~J}$.

\section{C.2.5 Fuel Fabrication}

Fuel fabrication consists in converting the enriched $\mathrm{UF}_{6}$ to $a$ form usable as reactor fuel. Pelletized uranium dioxide $\left(\mathrm{UO}_{2}\right)$ is the most common fuel form used in LWR. The enriched $\mathrm{UF}_{6}$ is hydrolized to $\mathrm{UO}_{2} \mathrm{~F}_{2}$, reacted with $\mathrm{NH}_{3}$ to form ammonium diuranate, calcined to $\mathrm{UO}_{3}$, and finally reduced with hydrogen to $\mathrm{UO}_{2}$ at $800^{\circ} \mathrm{C} .4$

Fabrication of a fuel assembly involves screening and compacting the $r$ aw $\mathrm{UO}_{2}$, pelletizing it under high pressure, and sintering it at high temperature. After the uranium content is determined, the high-density pellets are inserted into cladding tubes. The preferred cladding materials are aluminum for moderate-temperature reactors and stainless steel or zircalloy for high-temperature reactors.

In 1975, ten fuel fabrication facilities of three types were operating: four plants were equipped to produce $\mathrm{UO}_{2}$-pellets, three encased the pellets, and three were designed for integrated operations. ${ }^{2}$ For the IEA study, 1 an integrated facility was assumed.

The energy requirements were evaluated for a plant producing 600 $t / y r$ of enriched uranium in fuel elements, with a service life of 30 years. The energy requirements shown in Table C.7 are scaled to the needs of a 1000-MWe LWR, and represent the annual fabrication of $22.77 \mathrm{t}$ of enriched uranium into fuel elments.

Material requirements of the process represent the major energy use, attributable to the required cladding materials. The fuel fabrication step 
Table C.7. Energy Requirements for LWR Fuel Fabrication

\begin{tabular}{lcc}
\hline \multicolumn{1}{c}{ Energy Requirement } & $\begin{array}{c}\text { Electricity } \\
(\text { MWh/yr })\end{array}$ & $\begin{array}{c}\text { Other Energy } \\
\left(10^{12} \mathrm{~J} / \mathrm{yr}\right)\end{array}$ \\
\hline $\begin{array}{l}\text { Direct } \\
\text { Electricity } \\
\quad \text { Natural Gas }\left(135,398 \mathrm{~m}^{3},\right. \\
\left.\quad 38.4 \times 10^{6} \mathrm{~J} / \mathrm{m}^{3}\right)\end{array}$ & 2257.7 & - \\
Process Materials & - & 5.2 \\
Plant Construction & 4572 & 55.5 \\
$\quad$ Construction Material & & 0.7 \\
$\quad$ Direct & 20.2 & 0.2 \\
Total & 0.95 & 61.6 \\
Per Metric Ton of Enriched Uranium & 300.9 & 2.71 \\
\hline
\end{tabular}

represents $2.8 \%$ of the fuel cycle energy requirements. No loss of enriched uranium is assumed; therefore, the material energy equivalent leaving this step remains at $60,515 \times 10^{12} \mathrm{~J}$.

\section{C.2.6 Reactor}

The reactor analyzed is assumed to be a 1000-MWe light water reactor (LWR) operating at an average capacity factor of $61 \%$ over a service life of 30 years. The lifetime electrical output from such a facility is $160,300,000 \mathrm{MWh}$ $\left(577,085 \times 10^{12} \mathrm{~J}\right) ; 3.5 \%$ of this power is used in operating the station. The capacity schedule of this projected facility is as follows:

Five-month period before commercial operation: $40 \%$

First two years of commercial operation: $65 \%$

Years 3 through 15: $70 \%$

Last 15 years ( $2 \%$ decrease per year): $68 \%$ to $40 \%$

The direct energy requirements and process materials energy were estimated by IEAl using data scaled for a 1000-MWe facility. The direct fuel consumption is primarily for operation of the auxiliary equipment, which must remain operational even when the reactor is not functioning. Fuel consumption amounts to $344 \mathrm{~m}^{3} / \mathrm{yr}(90,900 \mathrm{gal} / \mathrm{yr})$ of diesel fuel.

The largest requirements for process materials energy are for fabrication and replacement of metal products such as valves, pipes, and supports, and chemicals required in water treatment in the boiler-turbine cycle. These 
annual operating expenses are comparable to the 30-yr amortized values for plant construction energy.

The amounts of energy required for reactor construction that were used in this report were provided by the IEA study, 1 augmented as necessary with data from Bechtel.5 These two studies differed in that IEA considered a reactor using once-through cooling whereas Bechtel assumed that cooling towers were used. The two studies nevertheless arrived at similar estimates of total energy input.

The IEA study did not specify the precise calegories and amounts of materials on which its estimates of construction material energy were based; those unrecorded details were taken from an SRI study that was not readily available. To give some indication of the material requirements for reactor construction, other studies 5,6 were consulted. Table C.8 shows a breakdown, for various functional subsystems, of amounts of construction materials estimated by Noguchi 6 for a 1000-MWe LWR installation; Table C.9 shows the major categories of equipment included in each subsystem. For comparison, Table C.10 shows total construction materials estimated by Bechtel5 (scaled to a 1000-MWe LWR); these estimates include raw materials for construction and materials contained in finished equipment procured for installation. The two sets of estimates in Tables $C .8$ and $C .10$ differ appreciably in their material requirements; however, if these materials were converted to energy value equivalents they would likely bracket the energy values reported by IEA and used in this study.

Table C.8. Major Material Requirements for a 1000-MWe LWRa

\begin{tabular}{|c|c|c|c|c|c|}
\hline \multirow[b]{2}{*}{ Materials } & \multicolumn{5}{|c|}{ Materia1 Requirements, $t$} \\
\hline & Reactor & $\begin{array}{l}\text { Turbine/ } \\
\text { Ccnerater }\end{array}$ & A1,1xilliary & Shared & Total \\
\hline $\begin{array}{l}\text { Concrete } \\
\text { Carbon Steel } \\
\text { Stainless Steel }\end{array}$ & $\begin{array}{r}85,071 \\
11,191 \\
2,207\end{array}$ & $\begin{array}{r}26,079 \\
9,215 \\
1,645\end{array}$ & $\begin{array}{r}35,515 \\
2,891 \\
712\end{array}$ & $\begin{array}{r}21,985 \\
2,973 \\
--\end{array}$ & $\begin{array}{r}168,650 \\
26,270 \\
4,564\end{array}$ \\
\hline $\begin{array}{l}\text { Copper } \\
\text { Aluminum }\end{array}$ & 18 & $\begin{array}{r}144 \\
--\end{array}$ & $\begin{array}{l}10 \\
--\end{array}$ & $\begin{array}{l}39 \\
81\end{array}$ & $\begin{array}{r}211 \\
81\end{array}$ \\
\hline
\end{tabular}

asource: Ref. 6 . 
Table C.9. Major Categories for Plant Groupings Shown in Table C.8

\begin{tabular}{llcc}
\hline \multicolumn{1}{c}{ Reactor } & Turbine/Generator & Auxiliary & Shared \\
\hline Building & Building & Fuel Storage Bldg. & Site Improve- \\
Auxiliary Reactor & Tur/Gen Equipment & Safeguard Cooling & ments and \\
Building & Feedwater System & System & Facilities \\
Reactor Equipment & Condensing System & Rad. Waste and & Misc. Buildings \\
Main Heat Transfer & Instrument and & Disposal & Electrical \\
System & Control & Fuel Handing and & Plant Equip- \\
Instruments and & Other Equipment & Storage & ment \\
Controls & & Circulating Water & \\
Other Equipment & & System & Intake and Discharge \\
& & Structures & \\
\end{tabular}

Table C.10. Major Material Requirements (Metric tons) for a 1000-MWe $\mathrm{LWR}^{\mathrm{a}}$

\begin{tabular}{lrlr}
\hline Carbon Stee1 & 47,800 & Steel Castings & 315 \\
Low-Alloy Steel & 4,860 & Aluminum Castings & 47 \\
Stainless Steel & 2,025 & Brass \& Bronze Castings & 80 \\
Copper & 2,305 & Iron \& Steel Forgings & 372 \\
Aluminum & 670 & Structural Steel Shapes & 8,263 \\
Manganese & 413 & Steel Plate (1.5 in) & 5,652 \\
Chromium & 477 & Steel Platè (1.5 in) & 1,796 \\
Nickel & 82 & Cement & 59,575 \\
Cast Iron & 900 & Concrete & 562,815 \\
\hline
\end{tabular}

asource: $\operatorname{Ref.} 5$.

Use of cooling towers instead of once-through cooling systems would increase the energy requirements for the reactor. Although the actual energy increases were not readily available, the differences, would be approximately as follows:

- Direct energy requirements for all auxiliaries would increase by about $1 \%$ to approximately 4 to $5 \%$.

- Cooling towers would become the most energy-intensive auxiliary in the reactor operation.

- Most of the direct energy would go towards operation of six to eight $3100-$ HP pumps.

- Process material requirements would increase because the cooling tower would require additional water treatment to inhlbic scaling, corrosion, and biofouling. 
- Construction energy would increase to include the energy content in the superstructure, pumps, fans, and. pipe materials.

Table C.11 provides the annual energy requirements for a 1000-MWe LWR. The reactor portion of the nuclear cycle represents the second largest energy use, amounting to more than $16 \%$ of the total energy input.

The reactor was assumed $33 \%$ efficient in production of electricity, yielding a gross power output of $19,933 \times 10^{12} \mathrm{~J} / \mathrm{yr}$. Allowing $3.5 \%$ of the power for internal results in a net power output of $19,235 \times 10^{12} \mathrm{~J} / \mathrm{yr}$.

\section{G.2.7 Epcnt Fucl Etorage}

Between one-third and one-quarter of the reactor fuel elements are removed and replaced with new fuel bundles annually. Although only a portion of the fissionable material is depleted in the fuel elements that are removed, the accumulated fission products in them reduce operating efficiency by absorbing neutrons.

The spent fuel rods removed from the reactor are highly radioactive and are therefore submerged. in water for cooling and decay of short-lived products. They are generally stored at the reactor site for several months to several years. The bulk of the material resources required for storage facilities is concrete and steel. Most storage systems consist of a pool, fuel storage racks, pool makeup system, pool cooling and filtering system, and a remoce-controlled tuel-handling system with jib cranes, grapples, and slings.

Table C.11. Annual Energy Requirements for' a 1000-MWe LWR

\begin{tabular}{lcc}
\hline \multicolumn{1}{c}{ Energy Requirement } & $\begin{array}{c}\text { Electricity } \\
(\text { MWh/yr })\end{array}$ & $\begin{array}{c}\text { Other Energy } \\
\left(10^{12} \mathrm{~J} / \mathrm{yr}\right)\end{array}$ \\
\hline $\begin{array}{l}\text { Direct } \\
\text { Diesel Fuel }\left(344 \mathrm{~m}^{3} \text { at }\right.\end{array}$ & -- & 13.3 \\
$\left.38.7 \times 10^{9} \mathrm{~J} / \mathrm{m}^{3}\right)$ & 8,551 & 287.6 \\
Process Materials & 6,543 & 271.6 \\
$\begin{array}{l}\text { Plant Construction } \\
\text { Materials } \\
\text { Direct }\end{array}$ & 15,382 & 65.3 \\
Total & $/ /$, & 637.8 \\
\hline
\end{tabular}


Fuel storage racks are of stainless steel, aluminum, and neutronabsorbing materials. A stainless steel rack will use from 150 to 250 tons of stainless steel; aluminum racks require about 75 to 150 tons of aluminum. 7

Many new or expanded storage plants currently are using a neutronabsorbing material as an integral part of rack construction. The commonly used materials are Boral plate (boron carbide dispersed in aluminum) or boron stainless stee1.7

Direct process and capital energy requirements were developed by ERDA in Appendix B of their National Plan for Energy Research, Development and. Demonstration. 2 The basis for their estimates for the storage of $22.77 \mathrm{t}$ of depleted uranium (containing about $0.8 \% \mathrm{U}^{235}$ ) each year was not reported in that document.

It is assumed that the estimates represent interim waste fuel storage at the reactor facility and longer-term storage either at another plant in the utility system or at a commercial storage facility.

A summary of the energy requirements for spent fuel storage, as developed by ERDA, 2 appears in Table C:12. "This portion of the nuclear cycle represents less than $0.3 \%$ of the cycle's total energy requirements.

The IEA values for this portion of the nuclear pathway are summarized in Table C.13. The values represent the energy requirements for the handling, packaging, and storing of the estimated ten canisters of waste accumulared each year. The dominant energy requirement is for the process materials:

Table C.12. Annụal Fuel Storage Requirements

\begin{tabular}{lcc}
\hline \multicolumn{1}{|c}{ Energy Requirement } & $\begin{array}{c}\text { Electricity } \\
(\text { MWh/yr })\end{array}$ & $\begin{array}{c}\text { Other Energy } \\
\left(10^{12} \mathrm{~J} / \mathrm{yr}\right)\end{array}$ \\
\hline $\begin{array}{l}\text { Direct } \\
\text { Electricity } \\
\text { Other Fuels }\end{array}$ & 242.7 & - \\
$\begin{array}{l}\text { Process Materials } \\
\text { Facility Construction } \\
\text { Materials } \\
\text { Direct Construction }\end{array}$ & 81 & 0.16 \\
Total & - & 2.26 \\
\hline
\end{tabular}


Table C.13. Waste Storage Annual Requirements

\begin{tabular}{lcc}
\hline \multicolumn{1}{c}{ Energy Requirement } & $\begin{array}{c}\text { Electricity } \\
(\mathrm{MWh} / \mathrm{yr})\end{array}$ & $\begin{array}{c}\text { Other Energy } \\
\left(10^{12} \mathrm{~J} / \mathrm{yr}\right)\end{array}$ \\
\hline $\begin{array}{l}\text { Direct } \\
\text { Electricity }\end{array}$ & 4.35 & -- \\
$\quad \begin{array}{l}\text { Liquid Fuel (Diesel: } \\
\left.2 \mathrm{~m}^{3} \text { at } 38.7 \times 10^{9} \mathrm{~J} / \mathrm{m}^{3}\right)\end{array}$ & - & 0.07 \\
Process Materials & 151.9 & 5.56 \\
P1ant Construction & & \\
$\quad$ Materials & 9.8 & 0.43 \\
Dircct Construction & 0.8 & 0.37 \\
Total & 166.85 & 6.43 \\
\hline
\end{tabular}

hydraulic cement and steel. These requirements amount to $6.43 \times 10^{12} \mathrm{~J} / \mathrm{yr}$ and represent about $0.2 \%$ of the full nuclear cycle energy requirements.

Terminal decommissioning of the reactor was not included in the analy.sis because no data are available.

\section{C.2.8 Waste Storage}

Low-level and intermediate-level radioactive wastes are generated during routine plant operation. These wastes include contaminated filter and adsorption materials, ion exchange resins contaminated during purification of the primary water system, and other radioactive materials, e.g., spent reactor parts. Liquid wastes are generally treated to reduce their volume before storage; sol d wastes are packaged and shipped to burial sites.

High-level radisactive waotes are pi incipally those accumulated during the purification stage of fuel reprocessing. Because this operation is not required in the state-of-the-art nuclear cycle (no reprocessing is currently taking place), energy values for reprocessing are nsed in lieu of storage and disposal of the low and intermediate level wastes that are evaluated.

\section{C.2.9 Transportation of Nuclear Materials}

The transportation of nuclear material occurs throughout all stages of the fuel cycle. Regulations adopted by the Department of Transportation and NRC emphasize the design of packaging and shipping containers, to protect the public and the workers. Radioactive waste is shipped by truck or rail 
over public transportation routes, and the regulations result in extra energy costs for the transport of fuel material and containers.

The transportation energy requirements reported by ERDA categorize transportation in two cycles, the first being the pre-enrichment transport of natural uranium and the second being the transport of enriched fuel or enriched uranium.

The transportation distances between the mine and the mill site are considered small since the mili is usually located near the mine site. The energy requirements for the trucks and fuels were slight and were included as part of the energy requirements of the milling operation.

The energy requirement for the transport of $\mathrm{U}_{3} \mathrm{O}_{8}$ from the mill to the purification $\mathrm{plant}$ was computed by assuming a typical travel distance, which was multiplied by a transportation intensity value $(\mathrm{J} / \mathrm{t}-\mathrm{km})$ and a "shipment factor." This shipment factor is the ratio of total cargo to total uranium. A distance of $1290 \mathrm{~km}$ ( $800 \mathrm{miles}$ ) was assumed, with an intensity factor of $1.96 \times 10^{6} \mathrm{~J} / \mathrm{t}-\mathrm{km}(2720 \mathrm{Btu} / \mathrm{ton}-\mathrm{mi})$ for truck haulage and a shipment factor of 1.5 to account for the containers, equipment, and oxygen content of the $\mathrm{U}_{3} \mathrm{O}_{8}$. This results in an estimate of $3.44 \times 10^{9} \mathrm{~J} / \mathrm{t}$ of uranium for transportation from the mill to the purification plant.

The energy requirement for material transport from the purification plant to the enrichment plant was calculaced similarly. A shipment factor of 2.24 was used to account for the containers required in the shipment of $\mathrm{UF}_{6}$ gas. The mileage between processing plants was assumed to be $1290 \mathrm{~km}(800$ miles) and the transport performed by truck; the direct energy required amounts to $5.2 \times 10^{9} \mathrm{~J}$. This information, scaled from the IEA report, is presented in Table C.14.

The direct transportation energy requirement includes the necessary shipping containers and other protective equipment. The indirect energy includes the energy content of the trucks and all loading, unloading, and docking facilities.

Post-enrichment transportation energy was similarly developed, but now represents enriched fuel rather than natural uranium. Also, transport by rail is included, with an energy intensity factor of $0.40 \times 10^{6} \mathrm{~J} / \mathrm{t}-\mathrm{km}$ (550 Btu/ton-iulle). The data are shown in Table C.15. 
Table C.14. Transportation Energy Requirements: Ore Mill to Enrichment Plant

\begin{tabular}{|c|c|c|c|c|c|}
\hline Transport Energy & $\begin{array}{l}\text { Shipment } \\
\text { Factor }\end{array}$ & $\begin{array}{l}\text { Dist ance } \\
\quad(\mathrm{km})\end{array}$ & $\begin{array}{c}\text { Energy } \\
\text { Intensity } \\
\left(10^{6} \mathrm{~J} / \mathrm{t}-\mathrm{km}\right)\end{array}$ & $\begin{array}{l}\text { Elec- } \\
\text { tricity } \\
(\mathrm{MWh} / \mathrm{yr})\end{array}$ & $\begin{array}{l}\text { Other } \\
\text { Energy } \\
\left(10^{12} \mathrm{~J} / \mathrm{yr}\right)\end{array}$ \\
\hline Indirect & - & - & - & 13.7 & 0.86 \\
\hline Direct (Total) & - & - & - & - & 1.12 \\
\hline Mil1 to Purification & 1.5 & 1,290 & 1.96 & - & 0.45 \\
\hline $\begin{array}{l}\text { Purification to } \\
\text { Enrichment }\end{array}$ & 2.24 & 1,290 & 1.96 & - & 0.67 \\
\hline Total Enorgy & - & $=$ & - & 13.7 & 1.98 \\
\hline
\end{tabular}

Table C.15. Transportation Energy Requirements: Enrichment to Storage or Reprocessing of Waste

\begin{tabular}{|c|c|c|c|c|c|}
\hline Transport Energy & $\begin{array}{l}\text { Shipment } \\
\text { Factor }\end{array}$ & $\begin{array}{c}\text { Distance } \\
(\mathrm{km})\end{array}$ & $\begin{array}{l}\text { Energy } \\
\text { Intensity } \\
\left(10^{6} \mathrm{~J} / \mathrm{t}-\mathrm{km}\right)\end{array}$ & $\begin{array}{l}\text { Elec- } \\
\text { tricity } \\
\text { (MWh/ } \\
\text { yr) }\end{array}$ & $\begin{array}{l}\text { Other } \\
\text { Energy } \\
\left(10^{12}\right. \\
\mathrm{J} / \mathrm{yr})\end{array}$ \\
\hline Indirect & - & - & - & 51.5 & 3.24 \\
\hline Direct (Total) & - & - & - & - & 4.24 \\
\hline Enrichment to Fabrication & 4.0 & 1,290 & 1.96 & - & 0.84 \\
\hline Fabrication to Reactor & 7.0 & 805 & 1.96 & - & 0.23 \\
\hline Reactor to Reprocessing: & & & . & 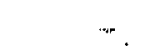 & \\
\hline Truck & 100 & 480 & 1.96 & - & 1.96 \\
\hline Rail & 30 & $1,77 ! n$ & 0.4 & - & 0.44 \\
\hline Waste Shipment & 10 & $1,6,10$ & 1.96 & $=$ & 0.65 \\
\hline Recycle of $\mathrm{U}+\mathrm{Pu}$ & 2.25 & 1,290 & 1.96 & - & 0.12 \\
\hline Total Energy & - & - & - & 51.5 & 7.48 \\
\hline
\end{tabular}

The transport of fuel does not have a sizeable impact upon the nuclear cycle's energy requirements; it amounts to about $0.2 \%$ of the total. Therefore, the above values would not change appreciably if reprocessing energies were not substituted for low-level waste storage. 


\section{3 ENERGY BALANCE PARAMETERS}

This analysis has discussed the energy requirements for each stage of the nuclear fuel cycle as. it exists today, including all fuel processing, transportation, and waste storage needed for supplying a 1000-MWe light water reactor with a 30-yr service 1 ife and an enrichment tails assay of $0.2 \%$, and excluding reprocessing of the residual uranium and plutonium in the spent fuel.

Figure C.2 shows an energy flow diagram for the nuclear cycle with resources, energy equivalence values, and losses. The energy flow values were based on the total power output of the plant operating according to the efficiencies described previously, i.e., a one-year annualized output of 1.92 $x 10^{16} \mathrm{~J}$. The residual energy remaining in the depleted fuel rods was considered as lost energy for purposes of this analysis.

Table C.16 summarizes the energy requirements for the entire fuel cycle, with electricity and fuel use converted to energy equivalents using the methodology of Appendix A.

\section{C.4 IDENTIFICATION OF SENSITIVE DATA}

Some possibilities exist for decreasing the overall energy requirements of the fuel cycle. Increasing the plant capacity from $61 \%$ to $75 \%$ would reduce the energy input requirements by about $5 \%$. Increasing the enrichment tails assay from $0.2 \%$ to $0.3 \%$ would reduce the energy input by approximately $15 \%$. Addition of fuel reprocessing would lower the energy input requirements by more than $20 \%$ (assuming no major changes in Llie syscem components), with the bulk of the energy reduction occurring from a decrease in the quantity of fuel requiring enrichment.

Reactor decommissioning and ultimate disposal of high-level wastes and spent fuel would add another step in the fuel cycle and slightly increase the energy input requirements reported here.

The greatest potential for increasing the net efficiency of the LWR fuel cycle is likely to occur in the enrichment operation. This report considers the enrichment operation by the gaseous diffusion process. However, gas centrifugation processes hold promise for drastically reducing directenergy requirements. The electrical input for centrifugation has been esti- 


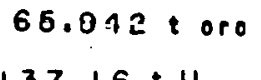
$137.16+U \quad 130.3+4$
191.7 tUF $_{6}$
$137.16+U$
$130.3+2$
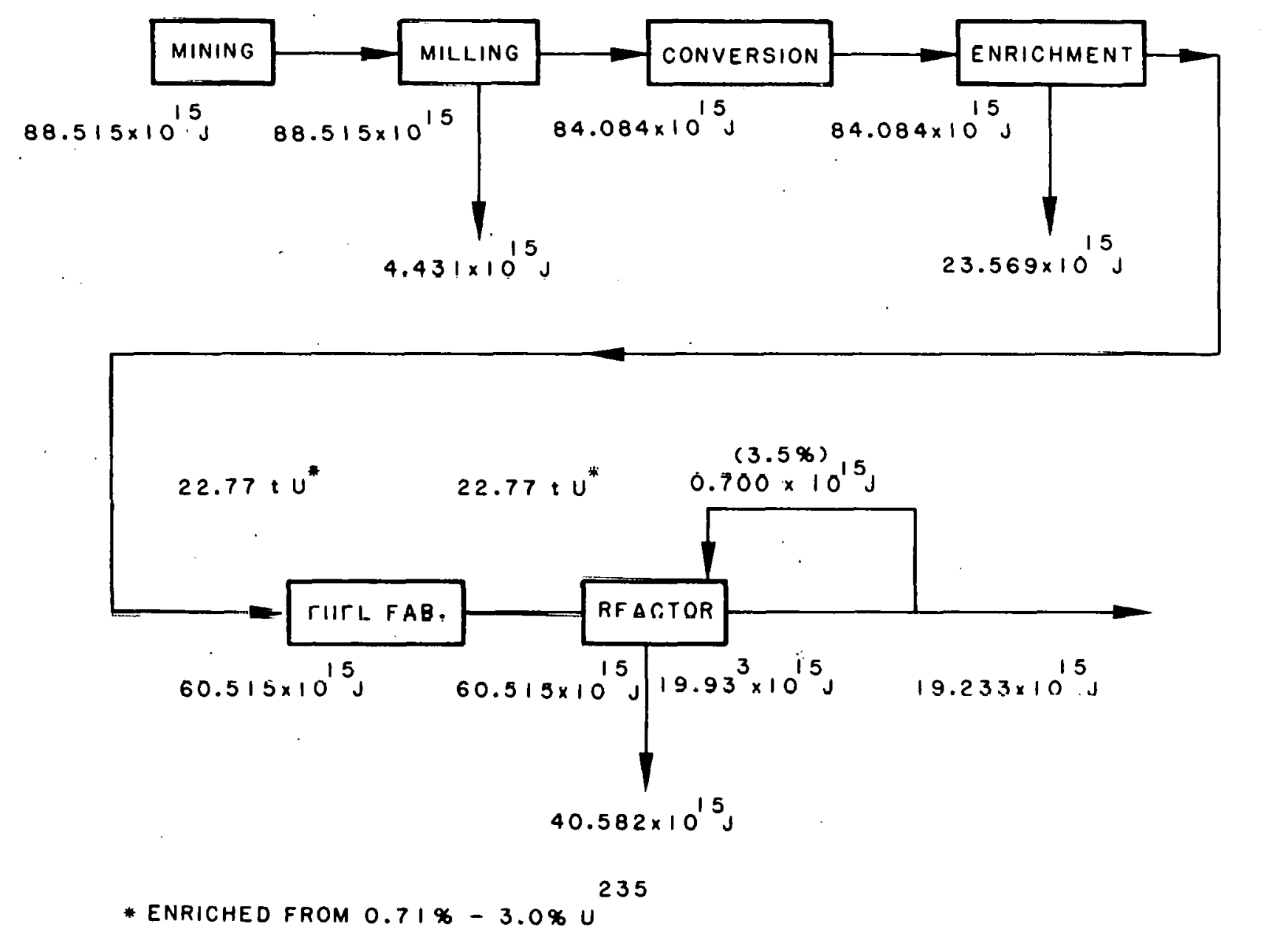

Fig. C.2. Energy Flow Pathway - Nuclear Fuel Cycle 
Table C.16. Energy. Palance Parameters for Nuclear LWR System

\begin{tabular}{|c|c|c|c|c|c|c|c|c|c|c|c|c|c|}
\hline \multirow[b]{2}{*}{$\begin{array}{l}\text { System } \\
\text { E lement }\end{array}$} & \multicolumn{3}{|c|}{ Annual Primary Input } & \multicolumn{3}{|c|}{ Toral Capical Inpurs } & \multicolumn{3}{|c|}{ Annual Operating Inputs } & \multicolumn{4}{|c|}{ Annual Primary Output } \\
\hline & Type & $\begin{array}{l}\text { Quantity } \\
\text { (t) }\end{array}$ & $\begin{array}{l}\text { Energy } \\
\left(101 y^{a}\right)\end{array}$ & Type & Quartity & $\begin{array}{l}\text { Energy } \\
\left(10^{b}{ }^{b}\right)\end{array}$ & Type & Quantity & $\begin{array}{r}\text { Energyb } \\
\left(10^{15} \mathrm{~J}\right) \\
\end{array}$ & Type & Quantity & & $\begin{array}{l}\text { Energy } \\
\left(1015^{a}\right. \\
\end{array}$ \\
\hline $\begin{array}{l}\text { Uranium } \\
\text { Mining }\end{array}$ & Uranium & 137.2 & 88.515 & $\begin{array}{l}\text { Electricity } \\
\text { Fuels } \\
\text { Total }\end{array}$ & $\begin{array}{c}6.21 \times 10^{6} \text { kwhe } \\
465.0 \times 10^{12} \mathrm{~J} \\
-\end{array}$ & $\begin{array}{l}0.0852 \\
0.5618 \\
0.6470 \\
\end{array}$ & $\begin{array}{l}\text { Electricity } \\
\text { Heavy fuel sil } \\
\text { Diesel fuel } \\
\text { Gasoline } \\
\text { Other peroleum } \\
\text { Natural gas } \\
\text { Process materials } \\
\text { Total }\end{array}$ & $\begin{array}{c}1.59 \times 10^{6} \mathrm{kWh}= \\
25.1 \mathrm{~m}^{3} / \mathrm{yr} \\
789.9 \mathrm{~m}^{3} / \mathrm{yr} \\
46.7 \mathrm{~m}^{3} / \mathrm{yr} \\
38.20 \mathrm{~m}^{3} / \mathrm{yr} \\
20,051 \mathrm{~m}^{3} / \mathrm{yr} \\
\mathrm{NA} \\
-\end{array}$ & $\begin{array}{l}0.0217 \\
0.0012 \\
0.0370 \\
0.0019 \\
0.0018 \\
0.0009 \\
0.0306 \\
0.0951\end{array}$ & Uranium & 137.26 & : & 88.515 \\
\hline $\begin{array}{l}\text { Uranium } \\
\text { Milling }\end{array}$ & Uranium & 137.2 & 88.515 & $\begin{array}{l}\text { Electricity } \\
\text { Fuels } \\
\text { Materials } \\
\text { Total. }\end{array}$ & $\begin{array}{c}0.11 \times 10^{5} \mathrm{kwhe} \\
27.0 \times 10^{12} \mathrm{~J} \\
\mathrm{NA} \\
-\end{array}$ & $\begin{array}{l}0.0015 \\
0.0326 \\
0.1350 \\
0.1691\end{array}$ & $\begin{array}{l}\text { Electricity } \\
\text { Heavy fuel oil } \\
\text { Diesel fuel } \\
\text { Gasoline } \\
\text { Other petroleum } \\
\text { Natural gas } \\
\text { Sulfuric acid } \\
\text { Other materials } \\
\text { Total }\end{array}$ & $\begin{array}{c}2.25 \times 10^{6} \mathrm{kwhe} \\
68.3 \mathrm{~m}^{3} / \mathrm{yr} \\
200.5 \mathrm{~m}^{3} / \mathrm{yr} \\
6.3 \mathrm{~m}^{3} / \mathrm{yr} \\
25.6 \mathrm{~m}^{3} / \mathrm{yr} \\
877,920 \mathrm{~m}^{3} / \mathrm{yr} \\
\text { NA } \\
\text { NA } \\
-\end{array}$ & $\begin{array}{l}0.0308 \\
0.0034 \\
0.0094 \\
0.0002 \\
0.0012 \\
0.0379 \\
0.0774 \\
0.0272 \\
0.1175\end{array}$ & Uranium & $130.3 \mathrm{t}$ & . & 84.084 \\
\hline Conzersion & Uranium & 130.3 & 84.084 & $\begin{array}{l}\text { Electricity } \\
\text { In materials } \\
\text { Fuels } \\
\text { Materials } \\
\text { Total }\end{array}$ & $\begin{array}{c}0.023 \times 13^{6} \mathrm{kWhe} \\
0.587 \times 13^{6} \mathrm{kWhe} \\
0.2 \times 11^{12} \mathrm{~J} \\
\text { NA } \\
-\end{array}$ & $\begin{array}{l}0.0003 \\
0.0081 \\
0.0073 \\
0.0240 \\
0.0397\end{array}$ & $\begin{array}{l}\text { Electricity } \\
\text { Natural gas } \\
\text { Process materials } \\
\text { Total }\end{array}$ & $\begin{array}{c}1.33 \times 10^{6} \mathrm{kWhe} \\
4.33 \times 10^{6} \mathrm{~m}^{3} / \mathrm{gr} \\
\mathrm{NA} \\
-\end{array}$ & $\begin{array}{l}0.0182 \\
0.1868 \\
0.0150 \\
0.2200\end{array}$ & $\mathrm{UF}_{6}$ & $191.7 t$ & & 84.084 \\
\hline Enrichment & $\mathrm{UF}_{6}$ & 191.7 & 84.084 & $\begin{array}{l}\text { Electricity } \\
\text { In materials } \\
\text { Fuels } \\
\text { Materials } \\
\text { Total }\end{array}$ & $\begin{array}{c}0.94 \times 13^{6} \mathrm{kwhe} \\
23.12 \times 13^{6} \mathrm{kWhe} \\
231.0 \times 10^{12} \mathrm{~J} \\
\text { NA } \\
-\end{array}$ & $\begin{array}{l}0.0129 \\
0.3168 \\
0.2790 \\
0.8400 \\
1.4487\end{array}$ & $\begin{array}{l}\text { Electricity } \\
\text { In materials } \\
\text { Casoline } \\
\text { Diesel Fuel } \\
\text { Propane } \\
\text { Coal } \\
\text { Process materials } \\
\text { Total }\end{array}$ & $\begin{array}{c}292.6 \times 10^{6} \mathrm{kWhe} \\
0.6 \times 10^{6} \mathrm{kWhe} \\
11.5 \mathrm{~m}^{3} / \mathrm{yr} \\
10.1 \mathrm{~m}^{3} / \mathrm{yr} \\
1.2 \mathrm{~m}^{3} / \mathrm{yr} \\
1289 \mathrm{r} / \mathrm{yr} \\
\mathrm{NA} \\
-\end{array}$ & $\begin{array}{l}4.0088 \\
0.0083 \\
0.0005 \\
0.0005 \\
0.00004 \\
0.0362 \\
0.0151 \\
4.0694\end{array}$ & $\begin{array}{l}\text { Enriched } \\
\text { Uranium }\end{array}$ & $22.8 \mathrm{c}$ & & 60.515 \\
\hline $\begin{array}{l}\text { Fuel } \\
\text { Fabrication }\end{array}$ & $\begin{array}{l}\text { Enriched } \\
\text { Uranium }\end{array}$ & 22.8 & 60.515 & $\begin{array}{l}\text { Electricity } \\
\text { In Meterials } \\
\text { Fuels } \\
\text { Materials } \\
\text { Total }\end{array}$ & $\begin{array}{c}0.03 \times 10^{5} \mathrm{kwhe} \\
0.61 \times 10^{5} \mathrm{kWhe} \\
6.0 \times 10^{12 \mathrm{~J}} \\
\mathrm{NA} \\
-\end{array}$ & $\begin{array}{l}0.0003 \\
0.0084 \\
0.0073 \\
0.0210 \\
0.0370\end{array}$ & $\begin{array}{l}\text { Electricity } \\
\text { In materials } \\
\text { Natural gas } \\
\text { Process materials } \\
\text { Total }\end{array}$ & $\begin{array}{c}2.26 \times 10^{6} \mathrm{kWhe} \\
4.57 \times 10^{6} \mathrm{kWhe} \\
0.14 \times 10^{6} \mathrm{~m}^{3} \\
\text { NA } \\
-\end{array}$ & $\begin{array}{l}0.0309 \\
0.0626 \\
0.0057 \\
0.0555 \\
0.1547\end{array}$ & $\begin{array}{l}\text { Enriched } \\
\text { Uranium }\end{array}$ & $22.8 \mathrm{t}$ & & 60.515 \\
\hline Reactor & $\begin{array}{l}\text { Enriched } \\
\text { Uranium }\end{array}$ & 22.8 & 60.515 & $\begin{array}{l}\text { Electricity } \\
\text { In materials } \\
\text { Fuels } \\
\text { Materials } \\
\text { Total }\end{array}$ & $\begin{array}{c}8.64 \times 1.0^{6} \mathrm{kWhe} \\
196.30 \times 10^{6} \mathrm{kWhe} \\
1.959 \times 10^{15} \mathrm{~J} \\
\text { NA } \\
-\end{array}$ & $\begin{array}{r}0.1185 \\
2.6892 \\
2.3669 \\
8.1480 \\
13.3226\end{array}$ & $\begin{array}{l}\text { Electricity } \\
\text { In materials } \\
\text { Diesel fuel } \\
\text { Process materials } \\
\text { Total }\end{array}$ & $\begin{array}{c}\left(0.19 \times 10^{9} \mathrm{kWhe}\right)^{c} \\
8.55 \times 10^{6} \mathrm{kWhe} \\
344 \mathrm{~m}^{3} \\
\mathrm{NA} \\
-\end{array}$ & $\begin{array}{l}(0.7000)^{c} \\
0.1172 \\
0.0161 \\
0.2876 \\
0.4209\end{array}$ & $\begin{array}{l}\text { Electricity } \\
\text { Gross } \\
\text { Internalc } \\
\text { Net }\end{array}$ & $\begin{array}{r}5.54 \times 10^{9} \\
60.19 \times 10^{9} \\
5.35 \times 10^{9}\end{array}$ & $\begin{array}{l}\text { khlhe } \\
\text { kthe) } \\
\text { kwhe }\end{array}$ & $\begin{array}{l}19.933 \\
(0.700) \\
19.233\end{array}$ \\
\hline $\begin{array}{l}\text { Spent Fuel } \\
\text { Scorage }\end{array}$ & $\begin{array}{l}\text { Depleted } \\
\text { Uranium }\end{array}$ & 22.8 & NA & $\begin{array}{l}\text { Electricity } \\
\text { Mater:als } \\
\text { Total }\end{array}$ & $\begin{array}{c}3.88 \times 10^{\circ 5} \mathrm{kWhe} \\
\mathrm{NA} \\
-\end{array}$ & $\begin{array}{l}0.0531 \\
0.1830 \\
0.2361\end{array}$ & $\begin{array}{l}\text { Electricity } \\
\text { In materials } \\
\text { Fuels } \\
\text { Process materials } \\
\text { Total }\end{array}$ & $\begin{array}{c}0.25 \times 10^{6} \mathrm{kwhe} \\
0.08 \times 10^{6} \mathrm{kWhe} \\
0.2 \times 10^{12} \mathrm{kwhe} \\
\mathrm{NA} \\
-\end{array}$ & $\begin{array}{l}0.0033 \\
0.0011 \\
0.0002 \\
0.0023 \\
0.0069\end{array}$ & & NA & & \\
\hline Wasce Storage & - & - & $\mathrm{NA}$ & $\begin{array}{l}\text { Elect:icity } \\
\text { Fuels } \\
\text { Mater:als } \\
\text { Total } \\
\quad\end{array}$ & $\begin{array}{c}0.02 \times 10^{6} \text { kwhe } \\
12.0 \times 10^{12} \mathrm{~J} \\
\mathrm{NA} \\
-\end{array}$ & $\begin{array}{l}0.0003 \\
0.0144 \\
0.0120 \\
0.0306\end{array}$ & $\begin{array}{l}\text { Electricity } \\
\text { In materials } \\
\text { Diesel fuel } \\
\text { Process materials } \\
\text { Total }\end{array}$ & $\begin{array}{c}0.004 \times 10^{6} \mathrm{kWhe} \\
0.15 \times 10^{6} \mathrm{kthe} \\
2 \quad \mathrm{~m}^{3} / \mathrm{yr} \\
\mathrm{NA}\end{array}$ & $\begin{array}{l}0.0006 \\
0.0021 \\
0.0012 \\
0.0056 \\
0.0079\end{array}$ & & NA & & \\
\hline Tracsport & - & - & NA & $\begin{array}{l}\text { Elect-icity } \\
\text { Materials } \\
\text { Total }\end{array}$ & $\begin{array}{c}1.96 \times 10^{6} \text { kWhe } \\
\mathrm{NA} \\
-\end{array}$ & $\begin{array}{l}0.0267 \\
0.1230 \\
0.1497\end{array}$ & Fuel & $5.36 \times 10^{12} \mathrm{~J}$, & 0.0065 & & NA & & \\
\hline
\end{tabular}

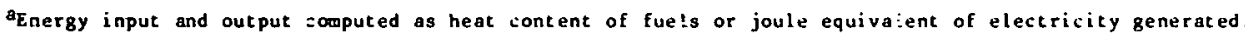

bcapital and operating energy input computed by $1 / 0$ analpsis as energy cosiz of fuels, materials, and elect picity used.

cInternal use, included in output totals only. 
mated at between $4 \%^{1}$ and $10 \%^{8}$ of current diffusion power requirements ( 100 to $250 \mathrm{kWh} / \mathrm{SWU}$ versus $2500 \mathrm{kWh} / \mathrm{SWU}$ ). Moreover, a $30 \%$ increase in enrichment capacity could be handled by existing utility grids. 8 Although cèntrifugation offers lower power consumption, it does not show a commensurate reduction in total cost per SWU. However, it still is thought to be more economical. 
REFERENCES TO APPENDIX $\mathrm{C}$

1. Perry, R., A. Perry and D. Reister, Net Energy from Nuclear Power, Institute for Energy Analysis; Oak Ridge "Associated Universities,', OEA-75-3 (Nov. 1975).

2. A National Plan for Energy Research, Development and Demonstration; Creating Energy Choices for the Future, Appendix B, ERDA 76-1 (Apr. 1976).

3. Woodmansee, W., Uranium, from Mineral Facts and Problems, Bureau of Mines, U.S. Dept. of Interior, p. 1185 (1975).

4. Babcock and Wilcox, Steam/Its Generation and Use, 38th Edition (1972).

5. Bechtel National, Inc., Resource Requirements, Impacts, and Potential Constraints Associated with Various Energy Futures, Contract 非X-77-C3794 for U.S. DOE, Report 非PAE-3794-9 (Aug. 1978).

6. Noguchi, T., Energy Requirement of a 1000 Me Pressurized Water Reactor Power Station, draft paper E-42, the University of Chicago, Resource Analysis Group (Dec. 1977).

7. Generic. EIS on Handling and Storage of Spent Light Water Reactor Fuel N.R.C., NREG-0404, Vols. 1 and 2 (Mar. 1978).

8. Ol ander, D., The Gas Centrifuge, Scientific American, V. 239(2), pp. 37-43 (Aug. 1978). 
THIS PAGE

WAS INTENTIONALLY

LEFT BLANK 
APPENDIX D

TERRESTRIAL SOLAR ENERGY SYSTEMS 
THIS PAGE

WAS INTENTIONALLY

LEFT BLANK 
This appendix describes the details of the terrestrial solar power systems used in the anaiysis. Both photovoltaic and thermal systems are discussed.

\section{1 PHOTOVOLTAIC SYSTEM}

\section{D.1.1 Description of the Overall system}

The conceptual design for the photovoltaic plant analyzed calls for an estimated peak capacity of 1000 MWe and a capacity factor of $55 \%$, with limited storage to compensate for loss of insolation. The plant is assumed to be operational 329 days (i.e., 90\%) of the year. With lithium/sulfur batteries capable of storing $6.097 \times 10^{12} \mathrm{~J} / \mathrm{day}$, the plant would operate 10 $\mathrm{hr} / \mathrm{day}$ to yield a total of $1.978 \times 10^{13} \mathrm{~J} / \mathrm{day}$ or $6.058 \times 10^{15} \mathrm{~J} / \mathrm{yr}$ given a daily mean insolation of $3.150 \times 10^{14} \mathrm{~J} / \mathrm{day}$. The plant's net efficiency for days of operation is $6.28 \%$. Plant $\mathrm{lifetime}$ is assumed to be 30 years, battery 1 ifetime to be 5 years, 1 and silicon cell 1 ifetime to be 30 years. A11 capital inputs are stated for a 30 -yr plant 1 ifetime.

\section{D.1.2 System Elements}

Figure D.l gives a schematic diagram of the elements of the system.

Inoolation. Iusulation is a diffuse energy source that varies with nearness to the equator and with regional climate factors such as cloud cover. The mean daily insolation is that solar energy which is normal to the earth's surface. The terrestrial photovoltaic plant analyzed is assumed to be situated in Barstow, California, 2 where the mean daily insolation is approximately 480 langleys (i.e., $2.01 \times 10^{7} \mathrm{~J} / \mathrm{m}^{2}$-day). The insolation used for this analysis is based on an average for the winter solstice, equinoxes, and summer solstice, assuming the use of a tracking reflector system that captures solar radiation equal to $3.39 \times 10^{7} \mathrm{~J} / \mathrm{m}^{2}$-day, somewhat more than the mean insolation of $2.01 \times 10^{7} \mathrm{~J} / \mathrm{m}^{2}$-day.

Solar Array Module. The solar array is composed of 50,000 singleaxis modules spaced on $32.9-m$ centers in a NS-EW grid pattern occupying $52 \mathrm{~km}^{2}$ $(12,840$ acres $)$. Each module is composed of 14 linear-foçus, reflective con= 


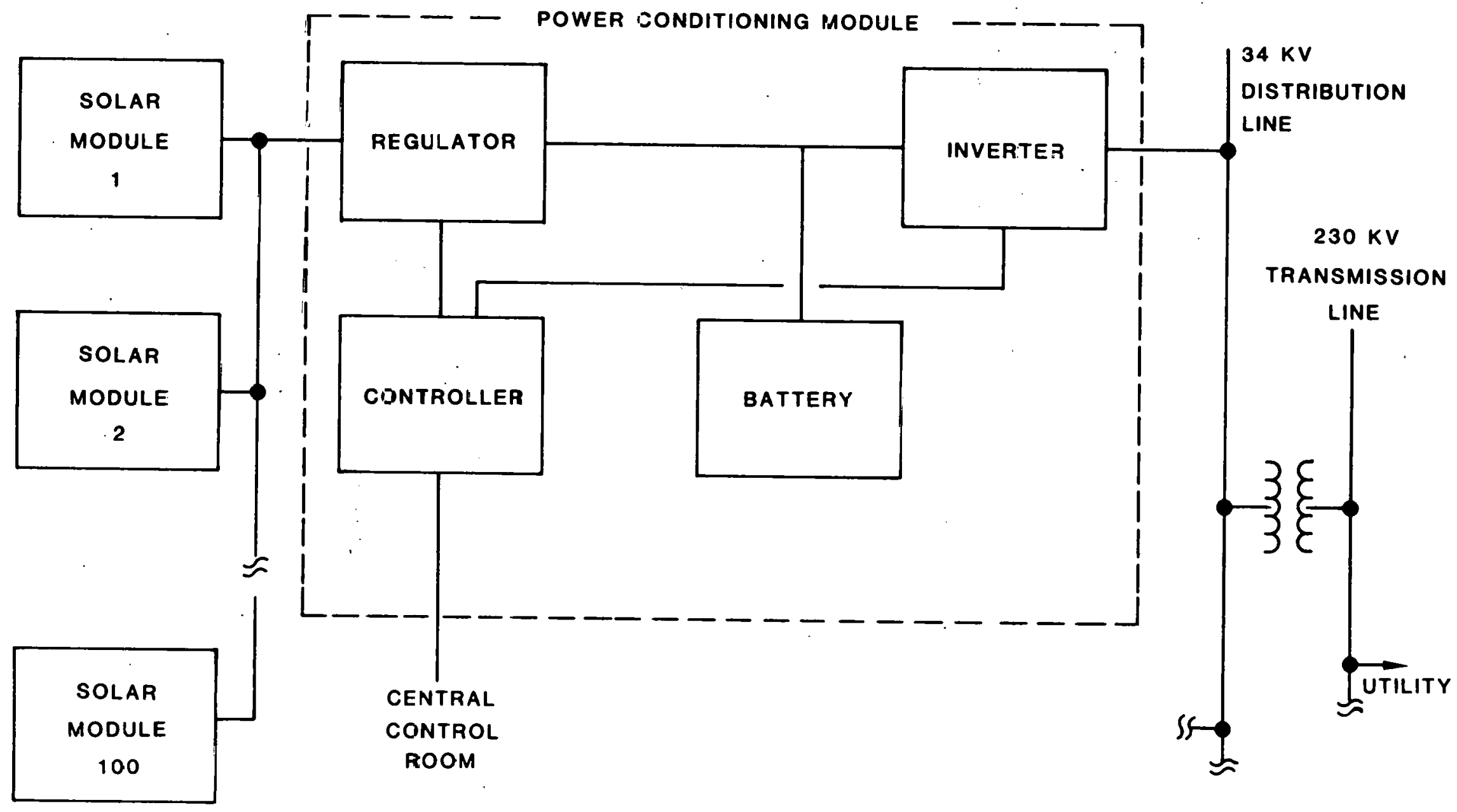

Fig. I.1. Power Conditioning Module Functional Block Diagram ${ }^{1}$ 
centrators (i.e., parabolic troughs). The troughs are arranged side by side on a plane inclined $45^{\circ}$ from the horizontal. The primary concentrator is 1.2 $\mathrm{m} \times 12.2 \mathrm{~m}$, with a $12.7 \mathrm{~cm} \times 12.2 \mathrm{~m}$ absorber strip mounted directly over the focal point of the trough. The total collector area of each module (less the surface area shaded by the absorber) is $186 \mathrm{~m}^{2}$. The geometric solar concentration ratio of the collector to absorber is 18 .

The absorber has a $6.1-\mathrm{cm} \times 12.20-\mathrm{m}$ strip of single silicon cells contained within a Winston-type concentrator with a $12.2 \mathrm{~cm}$ aperture. The absorber containing the silicon cells is passively cooled by ambient convection. Nominal cell temperature is $100^{\circ} \mathrm{C}$.

This solar array module was selected as representative of the current and near-term state of the art. Other photovoltaic materials as well as collector designs are currently being developed for possible commercialization in the future.

The primary energy input is $3.150 \times 10^{14} \mathrm{~J} / \mathrm{day}$, assuming the average daily insolation per year available with the tracking system in Barstow, California. The ancillary energy input is electrical energy used to rotate the solar modules; this energy is part of the $7.235 \times 10^{11} \mathrm{~J} /$ day $(3.5 \%$ of gross output) tapped from plant output as total auxiliary power. The principal capital input is $1.89 \times 10^{6} \mathrm{~kg}$ of pure monocrystalline silicon.

System output is $2.380 \times 10^{13} \mathrm{~J} / \mathrm{day}$ as electricity $\left(6.61 \times 10^{6} \mathrm{kWh} /\right.$ day), assuming the silicon cells are $16 \%$ efficient at $60^{\circ} \mathrm{C} .3$ The linear temperature correction equation for cell efficiency ${ }^{4}$ reduces the single cell efficiency to $13 \%$ at the operating temperature of $100^{\circ} \mathrm{C}$. The matrix of single cells (including the conductive bridge) occupies $85 \%^{3}$ of the total absorber area. Series resistance of the cell matrix results in a $10 \%$ energy $10 s$. $^{3}$ The parabolic trough collector has an efficiency of $69 \%$ with north-south tracking. The overall efficiency is the product of the efficiencies of the cell, the module, and the collector, which is equal to $7.55 \%$. Losses are reflected solar energy and heat released to the atmosphere, which total 2,914 x $10^{14} \mathrm{~J} / \mathrm{day}$.

Power Regulator, Controller, and DC Collection Network. The power regulator, in conjunction with the controller's microcomputer, follows the characteristics of the solar module for variations in solar input and temper- 
ature to maximize power output for each solar module. The power regulator and controller are part of the power conditioning module. There are 500 power conditioning modules, each servicing 100 solar modules. The power regulator consists of a smoothing reactor, and interphase reactor, and the direct current (DC) collection network.

The daily input to the collection network is $2.380 \times 10^{13} \mathrm{~J} / \mathrm{day}$ from the solar array. The ancillary energy inputs are in the form of electrical energy for operating switches and cooling fans; this ancillary energy is supplied by the plant.

rapital material inputs ${ }^{1}$ have becn aggregated for the entire plant: $835 \times 10^{6} \mathrm{~kg} \mathrm{atccl} ; 260$ a $10^{6} \mathrm{~kg}$ cement, $1.1 \times 10^{5} \mathrm{~m}^{3}$ water for cement, and $1.08 \times 10^{5} \mathrm{~kg}$ copper for the DC collection network. The gross ouput, at an overall efficiency of $98 \%, 5$ is $2.33 \times 10^{13} \mathrm{~J} /$ day of electrical energy. About $4.75 \times 10^{11} \mathrm{~J} /$ day is lost in electrical resistance and released to the environment as heat.

Lithium/Sulfur Storage Batteries. Lithium/sulfur batteries 1 will be located in a $3.7 \mathrm{~m} \times 16.8 \mathrm{~m}$ battery building, an all-steel construction with a $15 \mathrm{~cm}$-thick reinforced concrete floor. The battery bank will be $2.4 \mathrm{~m}$ $x 12.2 \mathrm{~m} \times 3.1 \mathrm{~m}$ high with a nominal weight of $79 \mathrm{t}$. The cells operate at $450^{\circ} \mathrm{C}$, but the batteries are insulated so that the exterior surface temperature is $32^{\circ} \mathrm{C}$. Auxiliary resistance heaters are embedded in the battery banks for reheat in the event of an idle period exceeding two days. Normally, however, self-generated heat will maintain the batteries within their operating temperature range, and no additional power will be needed. (Waste heat is removed by circulating air.) Should heat be required, the auxiliary heaters will expend about $1 \mathrm{~kW} / 100 \mathrm{~kW}$ generating capacity.

l'he primary energy. input to the batteries is $7.624 \times 10^{12} \mathrm{~J} / \mathrm{day}(2.12$ $x 10^{6} \mathrm{kWh} / \mathrm{day}$ ) for charging them. The major capital material input is $14.4 \mathrm{x}$ $10^{6} \mathrm{~kg}$ of 1 ithium, assuming a 5 -yr battery 1 ife.

The net output is $6.097 \times 10^{12} \mathrm{~J} / \mathrm{d}$ ay $\left(1.69 \times 10^{6} \mathrm{kWh} / \mathrm{day}\right)$. About $6.08 \times 10^{11} \mathrm{~J} / \mathrm{day}$ ( $8 \%$ of the input) is lost on charging, and $9.14 \times 10^{11} \mathrm{~J} / \mathrm{day}$ (about $12 \%$ of the input) is lost on discharging the batteries. These losses are expended to atmosphere as heat. 
$\mathrm{DC} / \mathrm{AC}$ Inverter. The $\mathrm{DC} / \mathrm{AC}$ inverter converts regulated $\mathrm{DC}$ to $60 \mathrm{~Hz}$ $\mathrm{AC}$ at $34 \mathrm{kV}$. An inverter is included in each of the 500 power conditioning modules. Total input is $6.097 \times 10^{12} \mathrm{~J} /$ day from battery storage and $1.570 \times$ $10^{13} \mathrm{~J} /$ day directly from the power regulators, for a total of $2.1797 \times 10^{13}$ $\mathrm{J} / \mathrm{day}\left(6.06 \times 10^{6} \mathrm{kWh} / \mathrm{day}\right)$. Thus about $72 \%$ of the total input to the inverters comes directly from the solar module; there are no ancillary inputs. Data on capital input materials were not available. Only the total inverter cost was available $\left(\$ 29.51 \times 10^{6}\right.$ in 1975 dollars $\left.{ }^{5}\right)$. This cost was converted to an energy equivalent using the input/output method described in Appendix A.

Transformer. Transformers are also included in the power conditioning modules; they convert the $34 \mathrm{kV}$ to $230 \mathrm{kV}$ for the AC transmission network. Total input is $1.999 \times 10^{13} \mathrm{~J} / \mathrm{day}$. There are no ancillary inputs. Data on capital inputs were 1 imited to costs $\left(\$ 34.63 \times 10^{6}\right.$ in 1975 dollars $\left.{ }^{5}\right)$.

Output is $1.978 \times 10^{13} \mathrm{~J} / \mathrm{d}$ ay or $6.508 \times 10^{15} \mathrm{~J} / \mathrm{yr}$ assuming 329 operating days per year and $99 \%$ efficiency. 5 . Losses are $1.999 \times 10^{11} \mathrm{~J} / \mathrm{day}$, as heat due to electrical resistance.

\section{D.1.3 Energy Balance Parameters}

Figure D.2 gives a schematic description of the energy flows in the terrestrial photovoltaic system. Table D.1 give the values of the parameters used in the net energy balance.

\section{D.1.4 Identification of Sensitive Parameters}

This section will describe some of the more sensitive data and indicate the ranges of possible values.

Insolation. The area chosen for the plant site is in the Southwest, which is the most suitable part of the U.S. for terrestrial solar energy. The Southwest has an average daily insolation of approximately $1.88 \times 107^{\circ}$ $\mathrm{J} / \mathrm{m}^{2}$-day. Some areas (El Paso, Phoenix, Tucson, etc.) receive as much insola$t$ ion as $2.41 \times 10^{7} \mathrm{~J} / \mathrm{m}^{2}$-day. The Midwest, North and East Coast have much lower average insolation levels of $1.5 \times 10^{7} \mathrm{~J} / \mathrm{m}^{2}$-day. Moreover, indirert, insolation from cloud cover cannot be effectively utilized by a tracking 
Table. D.1. Energy Balance Parameters for Terrestrial Solar Photovoltaic System

\begin{tabular}{|c|c|c|c|c|c|c|c|c|c|}
\hline \multirow[b]{2}{*}{$\begin{array}{l}\text { System } \\
\text { Element }\end{array}$} & \multirow[b]{2}{*}{ Type } & \multicolumn{2}{|c|}{1 Prinary Input } & \multicolumn{3}{|c|}{ Total Capital Inputs } & \multicolumn{3}{|c|}{ Annual Output } \\
\hline & & $\begin{array}{l}\text { Quantity } \\
\text { (kWhe) }\end{array}$ & $\begin{array}{l}\text { Energy } \\
\left(105^{a}\right)\end{array}$ & Type & Quantity ${ }^{b}$ & $\begin{array}{l}\text { Energyc } \\
\left(10^{15} \mathrm{~J}\right)\end{array}$ & Type & $\begin{array}{l}\text { Quantity } \\
\text { (kWhe) }\end{array}$ & $\begin{array}{l}\text { Energy } \\
\left(10^{a} 5^{\prime}\right)\end{array}$ \\
\hline Collector ${ }^{d}$ & $\begin{array}{l}\text { Solar } \\
\text { Radiazion }\end{array}$ & - & 115.048 & Silicon & $1,890 \mathrm{t}$ & $94.580^{\mathrm{E}}$ & Electricity & $2.18 \times 10^{9}$ & 7.830 \\
\hline $\begin{array}{l}\text { Power Regulator } \\
\text { Controller, DC } \\
\text { Collection Network }\end{array}$ & Elect=icity & 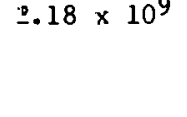 & 7.830 & Copper & $108 t$ & $0.027 \varepsilon$ & $\begin{array}{l}\text { Electricity } \\
\text { to Battery } \\
\text { to Inverter }\end{array}$ & $\begin{array}{l}0.70 \times 10^{9} \\
1.43 \times 10^{9}\end{array}$ & $\begin{array}{l}2.508 \\
5.165\end{array}$ \\
\hline Batteryd & Elect $=$ icity & $0.70 \times 10^{9}$ & 2.508 & Lithium & $2,400 t$ & 6.480 & $\begin{array}{l}\text { Electricity } \\
\text { tc Inverter }\end{array}$ & $0.56 \times 10^{9}$ & 2.006 \\
\hline Inverter & Elect $=1$ city & $=.99 \times 10^{9}$ & 7.171 & Equifment & $\$ 29,510,000$ & 1.370 & Electricity & $1.89 \times 10^{9}$ & 6.814 \\
\hline $\begin{array}{l}\text { AC Distribution } \\
\text { Line System }\end{array}$ & Elect=icity & $-.89 \times 10^{9}$ & 6.814 & $-\cdots--$ (Inc & uded below:-- & ----- & $\begin{array}{l}\text { Electricity } \\
\text { Gross } \\
\text { Ir.ternald } \\
\text { Net }\end{array}$ & $\begin{array}{l}1.89 \times 10^{9} \\
(0.07 \times 109)^{d} \\
1.82 \times 10^{9}\end{array}$ & $\begin{array}{l}6.814 \\
(0.238)^{d} \\
6.576\end{array}$ \\
\hline Transformer & Elect-icity & $-.82 \times 10^{9}$ & 6.576 & $\begin{array}{l}\text { Main trars- } \\
\text { formers } \\
\text { Substation } \\
\text { transformers }\end{array}$ & $\begin{array}{l}\$ 28,570,000 \\
\$ 6,060,000\end{array}$ & $\begin{array}{l}1.601 \\
0.339\end{array}$ & Electricity & $1.81 \times 10^{9}$ & 6.508 \\
\hline Entire Plant & - & - & - & $\begin{array}{l}\text { Miscellaneous } \\
\text { Electrical } \\
\text { Equipment } \\
\text { Steel } \\
\text { Cemer.t }\end{array}$ & $\begin{array}{l}\$ 24,380,000 \\
835,000 \mathrm{t} \\
260,000 \mathrm{t}\end{array}$ & $\begin{array}{r}1.130 \\
22.500 \\
0.936\end{array}$ & & . & \\
\hline
\end{tabular}

aEnergy input and output is computed as heat content of fuels or joule equivalent of electricity generated.

bollar amounts are in 1975 dallars.

${ }^{c}$ Capital energy input computed by I/O analysis as energy cost of fuels, materials, and electricity used.

dAnnual operating input consists solel? of auxiliars electricity tapped from output for internal use: tbe tctal is shown as "Electricity-

Internal" under Annual Outpu=.

e Based on $13,900 \mathrm{kWht} / \mathrm{kg}$; current stare-of-the-art of manufacturing. 


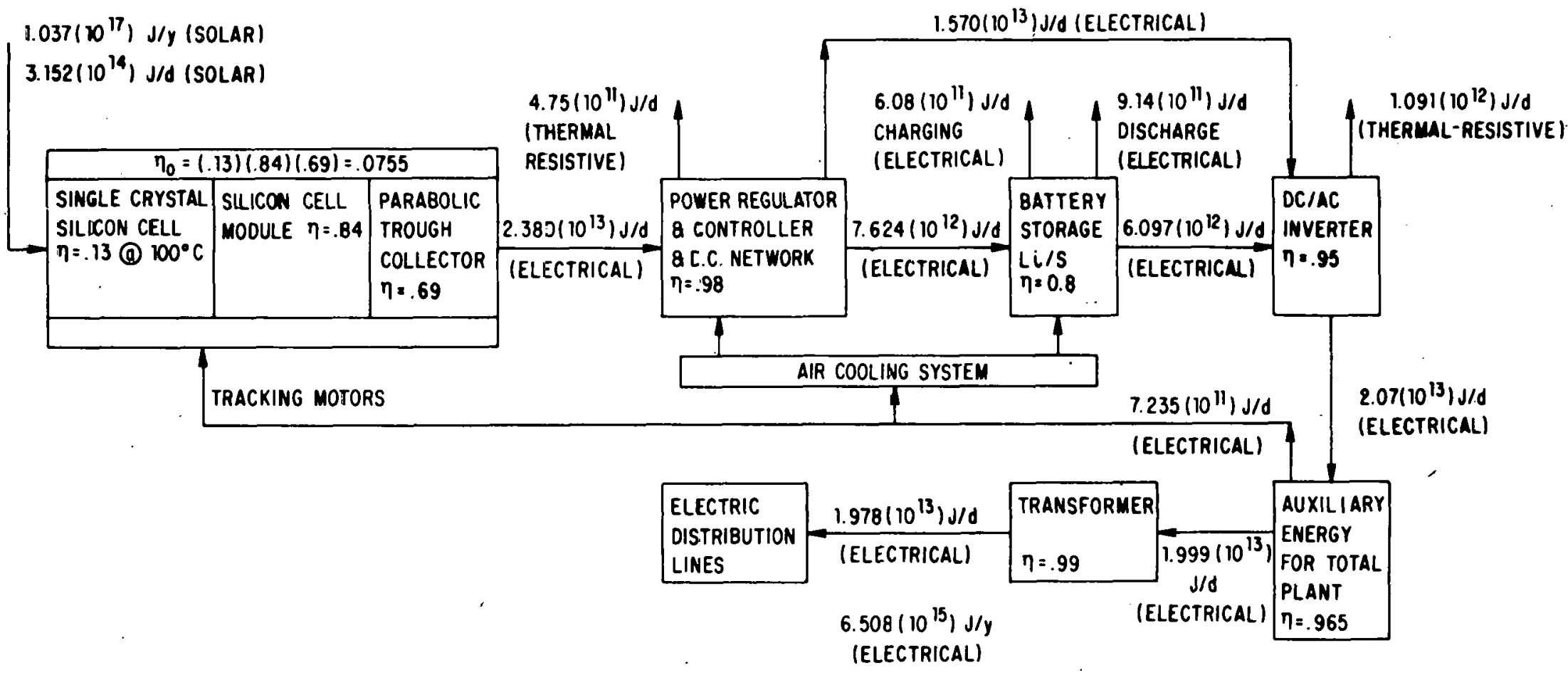

Fig D.2. Energy Flow of 1000-MWe Solar Photovoltaic Plant in Barstow, California 
system. If the representative plant were located in Chicago, where the average insolation is $1.47 \times 10^{7} \mathrm{~J} / \mathrm{m}^{2}$-day, the resulting daily output of electricity would be almost $30 \%$ less, although the energy investment in materials would be the same.

Photovoltaic Cells. Critical properties of photovoltaic materials are the bandgap energy, internal resistance, and cell,temperature. All these properties affect the generation of electricity.

Photovoltaic material is relatively transparent to light of wavelengths longer than the value of the bandgap energy leval.8 For cunohine at ground level, optimum bandgap energy is about 1.45 electron volts (eV), which is very close to the value for gallium arsenide $\left(1.43 \mathrm{eV}\right.$ at $\left.20^{\circ} \mathrm{C}\right)$ and somewhat greater than that for siliçon $\left(1.2 \mathrm{eV}\right.$ at $\left.20^{\circ} \mathrm{C}\right)$. Therefore gallium arsenide is able to convert more of the solar energy into electrical energy than silicon. Also, absolute heat-sink temperatures can be about $20 \%$ higher for gallium arsenide than for silicon. 8 This means that the output of electricity would decrease $20 \%$ less for gallium arsenide than for silicon as the temperature increases above reference temperature. Gallium arsenide is also unusual in that, at temperatures as high as $200^{\circ} \mathrm{C}$, it still has an efficienry nf $14 \%$ with a 270-fold concentration of solar radiation (i.e., geometric concentration ratio).

Table D.2 shows currently achieved and theoretical efficiencies of photovoltaic cells, and the efficiency goals set by DOE, which may be achievable with further development. The upper bound of efficiency of photovoltaic materials is $26 \%$ at $60^{\circ} \mathrm{C}$ and about $17.6 \%$ at $100^{\circ} \mathrm{C}$. The efficiency nf the photovoltaic material is the critical efficiency (i.e., smolleot refiriency) among the components of a photovoltaic generating plant. Replacement of silicon cells with gallium arsenide cells would increase plant output to 2.678 $x 101 \mathrm{~J} \mathrm{~J} / \mathrm{day}$, giving the plant a new net efficiency of $8.5 \%$ as opposed to $6.28 \%$.

Collectur. The efficiency of the collector may be increased by using a different design or more efficient materials (e.g., reducing reflected losses, or providing more accurate tracking of the sun). Improving the collector efficiency to $80 \%$ would increase output (all else being the same) to 
Table D.2. Solar Cell Efficiencies ${ }^{a}, b$

\begin{tabular}{|c|c|c|c|}
\hline \multirow{2}{*}{ Ce11 Type } & \multicolumn{3}{|c|}{ Efficiency, $\%$} \\
\hline & Achieved & Goal & Theoretical \\
\hline \multicolumn{4}{|l|}{ Silicon } \\
\hline Single Crystal & 16 & 18 & 22 \\
\hline Polycrystalline & 10 & 15 & 22 \\
\hline Amorphous & 5 & $\geqslant 10$ & unknown \\
\hline $\begin{array}{r}\text { Gallium Arsenide } \\
\text { Single Crystal }\end{array}$ & 18 & 20 & 26 \\
\hline Cadmium Sulfide & & & \\
\hline Vacuum Deposition & 8 & 12 & $14-16^{c}$ \\
\hline Spray & 5 & 10 & unknownd \\
\hline
\end{tabular}

asource: Ref. 3 .

$\mathrm{b}_{\mathrm{Without}}$ concentration and at reference temperature, $60^{\circ} \mathrm{C}$.

$c^{c_{T h e o t i c a l}}$ understanding is still in formative stages.

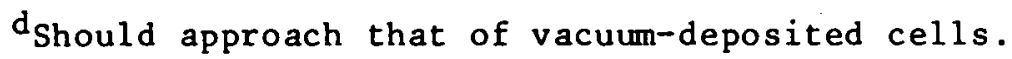

$2.293 \times 10^{13} \mathrm{~J} / \mathrm{day}$, raising the net plant efficiency to $7.28 \%$. However, increasing the solar flux at the absorber would increase the cell temperature and (especially for silicon) decrease electrical production. Also, if the photovoltaic cells were actively cooled, energy would have to be expended for cooling fluid or fans.

Concentration Factor of Collector. A collector with greater concentrating ability would increase the incident solar flux on the photovoltaic cell, and thus increase the electric energy generated per unit area of cell; however, the temperature would also increase, which reduces power generation (more so for silicon than for gallium arsenide). Also, as the current per cell increases with solar flux, so does the power lost through the cell's resistance. The usual resistance of solar cells is in the vicinity of 1 to 10 ohm-cm. The optimum resistance of the bulk material is about 0.1 to 0.3 ohm-cm. A variety of designs are under consideration that would reduce the resistance of the solar cell.10. These involve changing the geometry of the conventional planar cell in such a way that the series resistance is decreased. For instance, laboratory studies have indicated that use of a thick layer of aluminum gallium arsenide provides an improved series resist- 
ance by reducing the series resistance components. 10 Another low-resistance design is the edge-illuminated silicon cell, which has multiple seriesconnected junctions that are perpendicular to the front surface. Solid contacts and elimination of the need for current travel along a thin diffused sheet results in a greatly improved series resistance.

Energy Consumption for Si Production. The input energy requirements for silicon production have already been discussed in Appendix A.

\section{2 THERMAL SYSTEMS}

\section{D.2.1 Description of the Overall System}

The terrestrial solar thermal electric plant is based on a two-year research and development program to develop technology for a 10-MWe centralreceiver pilot plant, which is currently being built in Barstow, California under the sponsorship of DOE. The system evaluated is a 100-MWe design which has been designated as the commercial scale plant. Under the sponsorship of DOE and the technical management of Sandia Laboratories, three contract teams, headed by Honeywe 11, Martin Marrietta, and McDonnell Douglas, completed parallel and competing programs to develop conceptual designs for a pilot plant of 10 MWe as a basis for a 100-MWe commercial plant. The McDonnell Douglas design was chosen, and was used as the basis for this evaluation.

\section{D.2.2 System E1 ements}

Figure D. 3 gives a schematic diagram of the system elements described below.

Insolation. The representative terrestrial thermal plant is assumed to be situated in Barstow, California, where average insolation is $3.39 \times 10^{\prime}$ $\mathrm{J} / \mathrm{m}^{2}-\mathrm{day}$, as discussed in Section D.1.2.

Sollector. The collector io a flat glass plate heliostat with a front-surface silver coating under an acrylic coating. The heliostat has a reflective area of $38 \mathrm{~m}^{2}(6.1 \mathrm{~m}$ square) with a net reflectivity of $91 \%$. Heliostats have motor drives to position them both vertically and horizon- 


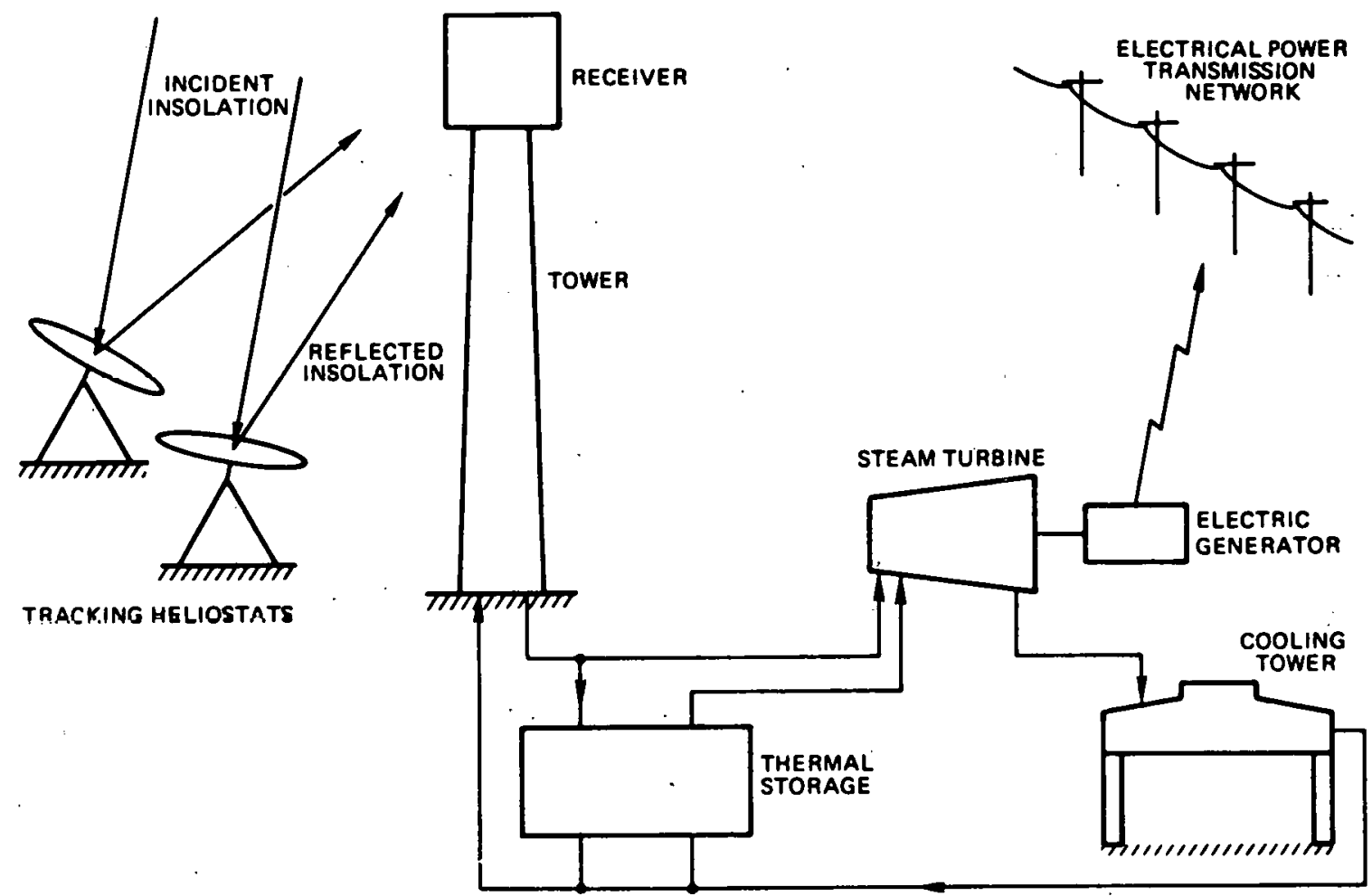

Fig. D.3. Schematic Diagram of Solar Thermal Plant 
tally. The collector array consists of 22,914 heliostats spaced around a central receiver tower in a staggered radial pattern. The heliostats total $869,586 \mathrm{~m}^{2}$ of glass, and occupy $3.66 \times 10^{6} \mathrm{~m}^{2}$ of 1 and.

Primary energy input to the heliostats is $2.95 \times 10^{13} \mathrm{~J} / \mathrm{day}$, assuming tracking of daily insolation averaged for the winter solstice, equinoxes, and summer solstice. This amounts to $1.077 \times 10^{16} \mathrm{~J} / \mathrm{yr}$ for direct sunshine $90 \%$ of the year ( 329 days/yr). Ancillary energy inputs include electrical power to drive the heliostat tracking motors, rated at 12 watts per heliostat. This power is taken from the plant output, and is part of an estimated total ancillary power need of $3.5 \%$ of total plant output. 6

The capital matcrial inputs are glass $(1.088 \times 10 / \mathrm{kg})$, stee. $(1.998 \mathrm{x}$ $\left.10^{7} \mathrm{~kg}\right)$, and concrete $\left(1.888 \times 10^{7} \mathrm{~kg}\right)$.

The heliostat output is $1.638 \times 10^{13} \mathrm{~J} / \mathrm{day}$ of solar energy reflected to the receiver, assuming a net collection efficiency of $55.5 \% .13$ About 1.314 $x 10^{13} \mathrm{~J} / \mathrm{day}$ of solar energy is lost by being reflected into the atmosphere.

Receiver and Boiler. The receiver consists of 24 panels of Incoloy 800 tubing. Twenty panels are external, single-pass-through superheat boilers, and four are preheating panels, located on the south side of the receiver. The tubes are coated with Pyromark paint, which has $95 \%$ absorptivity over a wide range of wavelengths. The boiler tubes cover a cylinder $421 \mathrm{~m}$ in diameter, mounted atop a 242-m tower located in the optimum focal center of the rollector array.

The primary energy input to the receiver is $1.638 \times 10^{13} \mathrm{~J} / \mathrm{day}$ of solar energy reflected by the tracking heliostats. There are no operating energy inputs.

The capital inputs 4 are: receiver steel $\left(94.64 \times 10^{3} \mathrm{~kg}\right)$, tower etcel $\left(1.126 \times 10^{6} \mathrm{~kg}\right)$, aud luwer concrete $\left(? .6491 \times 10^{7} \mathrm{~kg}\right)$.

The system output is $1.378 \times 10^{13} \mathrm{~J} / \mathrm{day}$ as pressurized steam from a receiver designed for an incident peak flux of $0.31 \mathrm{MW} / \mathrm{m}^{2} .13$ This yields a net efficiency of $84 \% ; 2.61 \times 10^{12} \mathrm{~J} /$ day are lost to the atmosphere as radiant heat energy. 
Riser/Downcomer System. The riser and downcomer are two pipes, $242 \mathrm{~m}$ long, contained within the tower for circulation to storage and to the turbine.

The primary energy input is $1.378 \times 10^{13} \mathrm{~J} / \mathrm{day}$ of thermal energy from the receiver and boiler. The operating energy needed to pump cooled water from the cooling tower to the receiver is part of the overall ancillary energy requirement of $3.5 \%$ of plant output.

The capital input 4 is $27.60 \times 10^{3} \mathrm{~kg}$ of steel.

The net output is $1.3639 \times 10^{13} \mathrm{~J} / \mathrm{day}$ of thermal energy, of which $39.62 \%$, or $5.403 \times 10^{12} \mathrm{~J} / \mathrm{d}$ ay, goes to storage and $8.236 \times 10^{12} \mathrm{~J} /$ day goes directly to the turbine as steam at $510^{\circ} \mathrm{C}$ and $1800 \mathrm{psia}$. This output is based on an assumed piping efficiency of $99 \%$.

Storage. The McDonnell Douglas single-stage sensible heat system, using a dual storage medium of rock and oil, is assumed to be used for heat storage. The system consists of four tanks $18.3 \mathrm{~m}(60 \mathrm{ft}) \mathrm{tall}$ and $27.6 \mathrm{~m}$ (90.5 ft) in diameter, used in parallel. The basic heat-transfer fluid is Caloric HT 43, which has excellent stability and compatibility with rocks and construction materials up to $316^{\circ} \mathrm{C}\left(600^{\circ} \mathrm{F}\right)$.

The primary energy input is $5.403 \times 10^{12} \mathrm{~J} / \mathrm{day}$ of thermal energy in the form of pressurized steam from the receiver. The ancillary input is the electrical power, taken from plant output, to operate pumps for the heat exchanger.

The capital inputs 5 are Caloric HT 43 heat-transfer oil $\left(9400 \mathrm{~m}^{3}\right)$, sand and gravel $\left(8.10 \times 10^{7} \mathrm{~kg}\right)$, and steel for the tanks $\left(5.53 \times 10^{5} \mathrm{~kg}\right)$.

The output of the storage system is $4.59^{\circ} \times 10^{12} \mathrm{~J} / \mathrm{day}$ of thermal energy, with a net efficiency of $85 \% .3$ Thermal energy amounting to $8.099 x$ $10^{11} \mathrm{~J} / \mathrm{day}$ is lost by radiation.

Turbine, Condenser, Cooling Tower and Generator. A 3600-rpm dual admission turbine from G.E. is used.13 The primary energy input is $8.236 \mathrm{x}$ $10^{12} \mathrm{~J} /$ day of thermal energy in steam at $1800 \mathrm{psia}$ and $950^{\circ} \mathrm{F}\left(510^{\circ} \mathrm{C}\right)$ directly from the receiver and $4.59 \times 10^{12} \mathrm{~J} / \mathrm{day}$ in steam at $550^{\circ} \mathrm{F}\left(288^{\circ} \mathrm{C}\right)$ and $500 \mathrm{psia}$ from storage, for a total of $12.826 \times 10^{12} \mathrm{~J} / \mathrm{day}$. Ancillary electrical energy 
to drive pumps and fans for cooling towers and other equipment is part of the total internal electrical energy supplied by plant output.

The capital energy equivalent input for the various pieces of equipment include $324.0 \times 10^{12} \mathrm{~J}$ for the turbine and generator, $22.68 \times 10^{12} \mathrm{~J}$ for the condenser and other electrical equipment, $93.0 \times 10^{12} \mathrm{~J}$ for the wet cooling tower, and $20.19 \times 10^{12} \mathrm{~J}$ for makeup water and transport.

The net output is $3.95 \times 10^{12} \mathrm{~J} / \mathrm{day}$ of electrical energy, assuming a net operating efficiency of $33 \%$ for input from the receiver and $27 \%$ for input from storage. Because of the lower temperature and pressure of steam from storage, the turbine is derated slightly. A total of $8.869 \times 10^{12} \mathrm{~J} / \mathrm{day}$ of thermal energy is lost in the cooling tower output.

Transformer, AC Feeder Network, Power Conditioning. These components are conventional equipment for making the electrical characteristics (c.g., voltage and frequency) of the power compatible with the AC distribution network. The energy input to the power conditioning system is $3.819 \times 10^{12}$ $\mathrm{J} / \mathrm{day}$; the output is $3.74 \times 10^{12} \mathrm{~J} / \mathrm{day}$, assuming an efficiency of power conditioning of $98 \% .5$ Radiant heat equivalent to $7.56 \times 10^{11} \mathrm{~J} /$ day is 10 st due to electrical resistance.

\section{D.2.3 Encrgy Balance Parametcro}

Figure D. 4 gives a schematic description of the energy flows in the system. Table D. 3 gives the values of the parameters used in the net energy bal ance.

\section{D.2.4 Identification of Sensitive Parameters}

Insolation. The solat therulal system is as sensitive to the variation in insolation as is the photovoltaic system. This sensitivity has been discussed already in Sect. D.1.4.

Collector. Boeing Engineering and Construction, Seattle, Washington, under contract with DOE, has developed a preliminary design of a heliostat collector subsystem using circular membrane reflectors. The reflectors are "gravity focused" by controlling the tension in the reflective membranes. 


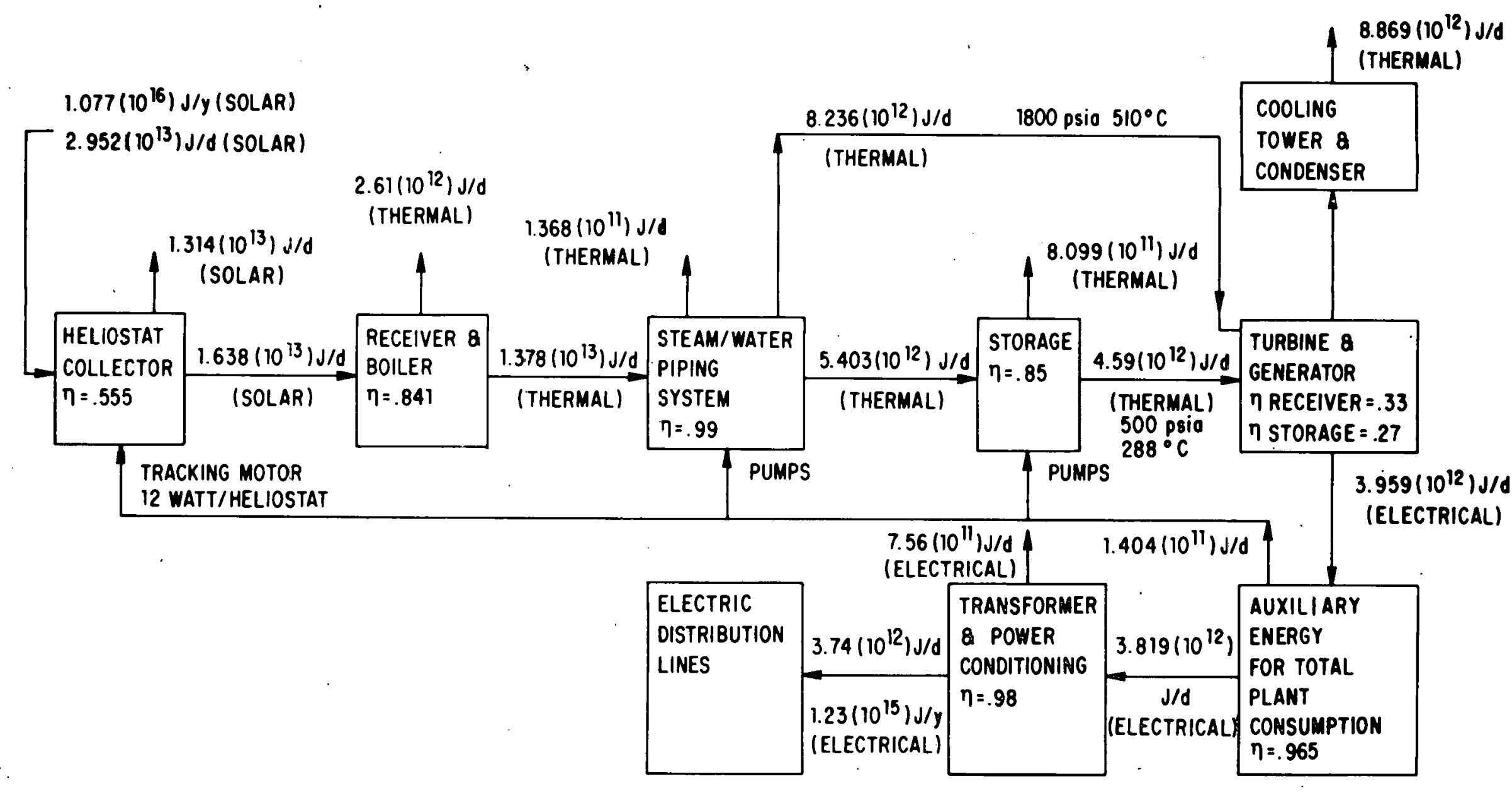


Table D.3. Energy $\mathrm{Ba}_{-}^{\circ}$ ance Parameters for Terrestrial Solar Thermal System

\begin{tabular}{|c|c|c|c|c|c|c|c|c|c|}
\hline \multirow[b]{2}{*}{$\begin{array}{l}\text { System } \\
\text { Element }\end{array}$} & \multicolumn{3}{|c|}{ Anrual P=imary Inpur } & \multicolumn{3}{|c|}{ Total Capital Inputs } & \multicolumn{3}{|c|}{ Annual Output } \\
\hline & Type & $\begin{array}{l}\text { Quantity } \\
\text { (kwhe) }\end{array}$ & $\begin{array}{l}\text { Lnergya } \\
\left.! 10^{15}{ }_{J}\right)\end{array}$ & Type & Zuantity & $\begin{array}{l}\text { Energ:b } \\
\left(10^{15}{ }_{J}\right)\end{array}$ & Type & $\begin{array}{l}\text { Quantity } \\
\text { (kWhe) }\end{array}$ & $\begin{array}{l}\text { Energy } \\
\left(10^{1} 5^{\prime}\right)\end{array}$ \\
\hline Collector ${ }^{c}$ & $\begin{array}{l}\text { Solar } \\
\text { Radiation }\end{array}$ & - & 10.775 & $\begin{array}{l}\text { Glass } \\
\text { Steel } \\
\text { Concrete } \\
\text { Total }\end{array}$ & $\begin{array}{l}19,880 \mathrm{t} \\
19,980 \mathrm{t} \\
13,980 \mathrm{t} \\
-\end{array}$ & $\begin{array}{l}0.126 .0 \\
0.5450 \\
0.068 .4 \\
0.73 .4\end{array}$ & Feat & - & 5.389 \\
\hline Receiver/Boiler & Heat & - & 5.389 & $\begin{array}{l}\text { Steel } \\
\text { Receiver } \\
\text { Tower } \\
\text { Tower Base } \\
\text { Concrete } \\
\text { Tower } \\
\text { Tower Base } \\
\text { Total }\end{array}$ & $\begin{array}{c}94.64 \mathrm{t} \\
354 \mathrm{t} \\
-072 \mathrm{t} \\
2.031 \cdot \mathrm{t} \\
24.461 \mathrm{t} \\
-\end{array}$ & $\begin{array}{l}0.00 \div 5 \\
0.00 \subseteq 4 \\
0.0257 \\
0.0073 \\
0.08 \varepsilon 1 \\
0.1370\end{array}$ & Heat & - & 4.534 \\
\hline Riser/Downcomer $r^{c}$ & Heat & - & 4.534 & Steel & $22.60 \mathrm{c}$ & 0.0007 & $\begin{array}{l}\text { Heat to Storage } \\
\text { Steam to Turbine }\end{array}$ & - & $\begin{array}{l}1.777 \\
2.711\end{array}$ \\
\hline Storage ${ }^{c}$ & Heat & - & 1.777 & $\begin{array}{l}\text { Calori= HT } 43 \text { oil } \\
\text { Sand \& Gravel } \\
\text { Steel } \\
\text { Total }\end{array}$ & $\begin{array}{l}9: 400 \mathrm{mi}^{3} \\
81,0 \mathrm{C} \mathrm{t} \\
555 \mathrm{t} \\
-\end{array}$ & $\begin{array}{l}0.4571 \\
0.0106 \\
0.0150 \\
0.4827\end{array}$ & Steam to Turbine & - & 1.510 \\
\hline Turbine/Generat $\supset r^{c}$ & Steam & - & 4.221 & General Equipment & NA & 0.324 & $\begin{array}{l}\text { Electricity } \\
\text { Gross } \\
\text { Internalc } \\
\text { Net }\end{array}$ & $\begin{array}{l}3.62 \times 10^{8} \\
\left(0.13 \times 10^{8}\right)^{c} \\
3.49 \times 10^{8}\end{array}$ & $\begin{array}{l}1.303 \\
(0.046)^{c} \\
1.257\end{array}$ \\
\hline $\begin{array}{l}\text { Transformer/Power } \\
\text { Cond it ioner }\end{array}$ & Electrieity & $3.49 \times 10^{8}$ & 1.257 & ------ (Inclu & uded above) - & $---\infty--$ & Electricity. & $3.42 \times 10^{8}$ & 1.230 \\
\hline $\begin{array}{l}\text { Miscel laneous } \\
\text { Equipment }\end{array}$ & - & NA & - & $\begin{array}{l}\text { Condenser } \dot{\alpha} \text { Other } \\
\text { Electrical } \\
\text { Equ:pment } \\
\text { Wet Cooling Tower } \\
\text { Makeup Hater } \\
\text { Transport } \\
\text { Total }\end{array}$ & $\begin{array}{c}\text { NA } \\
\text { NA } \\
\text { NA } \\
-\end{array}$ & $\begin{array}{l}0.0227 \\
0.093 \text { J } \\
0.020 ? \\
0.1359\end{array}$ & & & \\
\hline
\end{tabular}

anergy input and output is computed as heat contert of fuels or joule equivalent of electricity generated.

bCapital energy Input computed by I/O analysis as energy cost of fuels, materials, and electricity used.

cAnnual operating input consists solely of auxilia:y electricity tepped from output for internal use; the total is shown as "ElectricityInternal" under Annual Output. 
Transparent air-supported plastic-bubble enclosures protect the light-weight reflectors. Measurements were conducted in $1977^{1}$ on individual heliostats and on a group of three heliostats over a 4.5 month period. Results showed a nominal average efficiency of $69 \%$ to $72 \%$; after five months without cleaning, the reflectors still had a nominal average efficiency of $65 \%$, which is appreciably better than the $55.5 \%$ efficiency of the McDonnell Douglas system.

Receiver and Boiler. The present receiver/boiler system, which uses once-through forced flow, has a rated efficiency of $84.1 \% 13$, given an incident energy flux from the collector of $0.31 \mathrm{MW} / \mathrm{m}^{2}$. The original commercial-scale plant has a predicted design efficiency of $89.8 \%$, assuming an incident energy flux of $0.85 \mathrm{MW} / \mathrm{m}^{2}$; however, the life of the receiver tubes at this higher energy flux is uncertain. Mechanical oscillations may be induced by the severe temperature stress of this level of energy flux, which could cause early failure of the tubes due to structural fatigue. Once-through boilers have been built and operated at flux levels of $0.3 \mathrm{MW} / \mathrm{m}^{2}$, but apparently no once-through boiler has ever been built to operate at a flux as high as 0.85 $\mathrm{MW} / \mathrm{m}^{2}$.

Liquid Sodium System. The potential for higher plant efficiency has led to consideration of a second-generation solar thermal system using either a hot-gas or a liquid-metal cycle.11 Recent studies have confirmed the technical feasibility of using the exceptional heat-transfer capability of liquid sodium in a solar thermal power plant.

The system as conceived would use liquid sodium in the receiver/boiler, with sodium at $594^{\circ} \mathrm{C}\left(1,100^{\circ} \mathrm{F}\right)$ going directly to storage. Heat exchangers would be employed to transfer the heat to water, producing steam for the turbine. Having hot sodium in storage would allow the system to operate in steady-state condition during periods of cloud cover. Peak energy flux at the receiver is limited to $1.7 \mathrm{MW} / \mathrm{m}^{2}$ to achieve an assumed tube life of not less than 10,000 cycles; however, this level of energy flux is twice that of the McDonnell Douglas design $\left(0.85 \mathrm{MW} / \mathrm{m}^{2}\right)$.

The predicted turbine efficiency for a 100-MWe liquid sodium plant with six hours operating energy in storage is $39.4 \% 7$, as compared with turbine efficiencies of $33 \%$ (turbine feed from receiver) and $27 \%$ (turbine feed from 
storage) for the water system. (In the sodium system the turbine would always be fed from storage, so there is only one efficiency value to consider.) The advantage of liquid sodium as a receiver coolant is that scale formation is not a problem, as it is with water in the receiver. In addition, less pumping power is needed, and the low receiver pressure allows use of smaller-gauge tubing. This plus sodium's excellent heat-transfer characteristics substantially reduces the possibility. of thermal fatigue in the receiver tubes, which can be a real problem in water systems at heat fluxes higher than $0.6 \mathrm{MW} / \mathrm{m}^{2}$. 
REFERENCES TO APPENDIX D

1. Sears, R.D., D. V. Merrifield, M. M. Penny, Environmental Impact Statement for a Hypothetical 1000 MWe Photovoltaic Solar-Electric Plant, IERL, Report EPA 600/7-77-085 (Aug. 1977).

2. Annual Environmental Analysis Report: A Preliminary Environmentai Analysis of Energy Technologies Using the Assumptions of the National Energy Plan, Volume IV, The. MITRE Corporation/METREK Division,. CONSAD Research Corporation, Control Data Corporation, International Research and Technology, Inc., Draft Report (1977).

3. Evans, D. L. and L. W. Florschuet, Cost Studies on Terrestrial Photovoltaic Power Systems with Sunlight Concentration, Solar Energy, Vol. 19, pp. 255-262, Pergamon Press, Great Britain (1977).

4. Solar Assessment Study in Support of the International Ekistics Program, prepared by Arthur D. Little for Argonne National Laboratory, Report No. ANL/ ICES-TM-12 (July 1977).

5. Chowaniec, C. R., R. R. Ferber, et al., Solar Photovoltaic Power Stations, proceedings of the 1977 Annual Meeting of the American Section of the International. Solar Energy Society (1977).

6. Frabetti, A. J., et-al, A Stuly to Develop Energy Estimates of Merit for Selected Fuel Technologies, Final Report to U.S. Dept. of Interior, Office of Research and Development, Development Science, Inc. DSI038 (1975).

7. Cole, R., et al., Estimated Cost of Electricity Produced by Four Types of Compound Parabolice Concentrators, Proceedings of the 1977 Annual Meeting of the American Section of the International Solar Energy Society (1977).

8. Johnston, W.D., The Prospects for Photovoltaic Conversion, American Scientist, Vol. 65, pp. 736-739.

9. Hovel, H. J., Review Paper Solar Cells for Terrestrial Applications, Solar Energy, Vol. 19, pp. 605-615, Pergamon Press (1977).

10. Donne11, D. T., et al., Characteristics of Solar Cells Designed for Concentrator Systems, proceedings of the 1977 Annual Meeting of the American Section of the International Solar Energy Society, pp.23-1 to 23-5 (1977).

11. Highlights Report Solar Thermal Conversion Program Central Power Projects, Energy Research and Development Administration, Division of Solar Energy, SAND 77-8513 (1977).

12. Gandel, M. G., and P. A. Pillard, Assessment of Large-Scale Photovoltaic Materials Production, Industrial Environmental Research Laboratory, EPA600/7-77-087, Cincinnati (1977). 
13. Recommendations for the Conceptual Design of the Barstow, California, Solar Central Receiver Pilot Plant, Executive Summary, Solar Project Division 8132, Sandia Laboratories, SAND77-8035 (1977).

14. Meyers, A. C., A. E. Hildebrunt, Solar Tower-Thermal Collection Energy Component - 10 MNe Pilot Plant, Proceedings of the 1977 Annual Meeting of the American Section of the International Solar Energy Society, Vol. 1, pp. 20-11 to 20-15. (1977).

15. Mitche11, R. C., et al., Dual - Medium Thermal Storage System for Solar Thermal Power Plants, Proceedings of the 1977 Annual Meeting of the American Section of the International Solar Energy Society (1977).

16. Vant-Hu11, L. L., A Liquid Sodizon Cooled Solar Tower System, Pruceedings of the 1977 Annual Meeting of theAmerican Section of the International Solar Energy Soclecy (1977). 
ÄPPENDIX $\mathrm{E}$

SATELEITE POWER SYSTEM 
THIS PAGE

\section{WAS INTENTIONALLY}

\section{LEFT BLANK}




\section{E.1 DESCRIPTION OF OVERALL SYSTEM}

The satellite power system was suggested in 1968 by P.E. Glaser.1 It is a solar power cycle that involves generating electrical power from photovoltaic solar panels in geosynchronous orbit, transmitting the power to earth via focused microwave beams, and collecting and converting the beams into useful electricity on the earth's surface.

The system analyzed in this report 2,3 is designed as a $5-G W$ DC power unit that is connected to a conventional utility grid on the earth. The size of the satellite power system (SPS) is dictated primarily by the efficiency chain of the various elements in the system. Figure E.1 shows a simplified flow diagram and the end-to-end efficiency chain of the present SPS concept. 3 Two options are currently under consideration for converting solar energy into electrical energy: gallium aluminum arsenide (GaAlAs) solar cells with a concentration ratio of 2 and silicon ( $\mathrm{Si}$ ) solar cells with no concentration. The quoted efficiency is the minimum efficiency for a 30-yr lifetime, including the worst-case factor for solar radiation at the summer solstice $(0.9675)$, the seasonal variation $(0.91)$, and the end-of-life efficiency of solar cells, assuming annealing. 3

The capacity factor of the plant designed to provide $5 \mathrm{GW}$ of DC power to utility busbars is estimated to be $92 \%$, with a downtime of 696 hours $(87 \mathrm{day} / \mathrm{yr} \times 8 \mathrm{hr} / \mathrm{day})$ for maintenance. 4 . As a result, the elecericicy generated by the $5-G W$ SPS is expected to be $145.18 \times 10^{15} \mathrm{~J} / \mathrm{yr}\left(40.32 \times 10^{9}\right.$ $\mathrm{kWh} / \mathrm{yr}$ ).

\section{E.2 SYSTEM ELEMENTS}

The separate elements of the SPS illustrated in Fig. E.1 can be categorized into three groups: the solar energy collection system, the power distribution system, and the microwave power transmission system. The material requirements and the space transportation system to construct and operate a SPS are also key elements in studying the net energy balance. In this section these topics are briefly discussed, mainly on the basis of data in Ref. 3 .

\section{E.2.1 Solar Energy Collection System}

The solar energy collection system has the function of collecting the dispersed solar energy in sufficient quantities for conversion to electrical energy. 


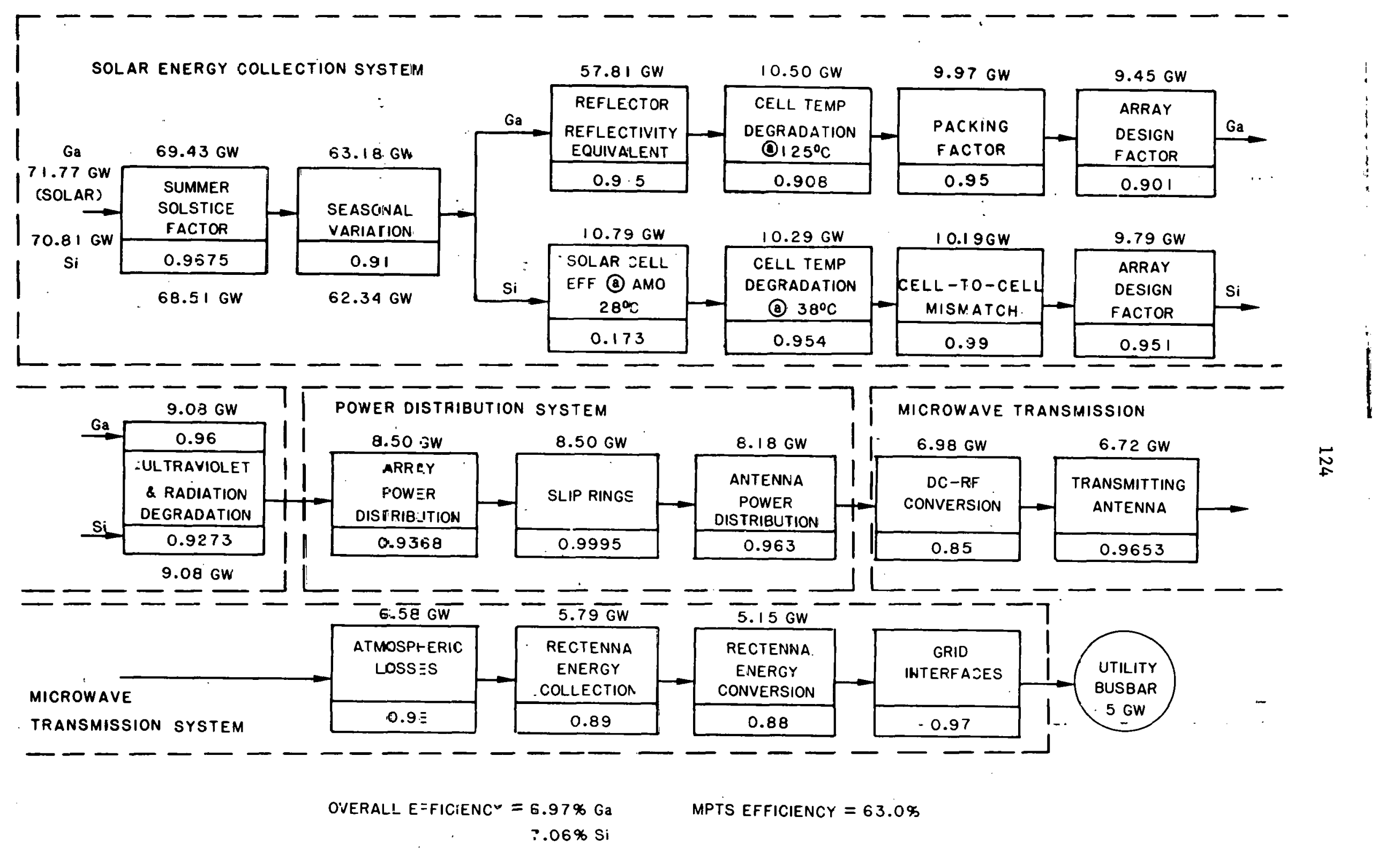

Fig. E.1. Simplified Flow Diagram and Ef Eiciency Chain of SPS (Ga CR=2 and Si CR=1)6 
In order to determine the most favorable energy collection/conversion system, a variety of studies were performed during 1974-1976, including solar photovoltaic systems, thermal conversion systems (solar Rankine cycle, solar Brayton cycle), orbiting nuclear power systems, and orbiting solar reflector systems.5 After a review of those systems, the photovoltaic system, using either single-crystal $\mathrm{Si}$ or GaAlAs cells, was chosen as the reference energyconversion device. A concentration ratio of one ( $C R 1$ ) is preferred for $\mathrm{Si-cell}$ systems, whereas GaAlAs cells may be more advantageous with a concentration ratio of two ( CR 2). Based on the analyses conducted to date, the results indicate the photovoltaic systems would be less complex and have lower mass than the thermal conversion systems regarded as competitive. The major disadvantages of thermal systems are the need to contain fluid, wear in rotating equipment, complexity of construction, and relatively high mass.

The solar array consists of the deployed solar cell blankets and their support structure. The basic GaAlAs solar cell consists of a $5-\mu m-t h i c k$ GaAs PN cell with a 0.03 to $0.05-\mu m-t h i c k$ GaAlAs front-side window. The blanket material is $25-\mu \mathrm{m}$-thick Kapton. The area of the blanket is $25.52 \mathrm{~km}^{2}$, deployed in a total area of $55.13 \mathrm{~km}^{2}$ for the GaAlAs system with CR2, which includes the solar reflectors mounted on each side of the solar cell blankets. The projected cost of the blankets is $\$ 71 / \mathrm{m}^{2}$.

The Si-cell blanket consists of 50- $\mu$ m-thick single-crystal si cells with a borosilicate covering electrostatically bonded to the front and back. The area of the blanket for the $S i$ system with CR 1 is $52.34 \mathrm{~km}^{2}$, deployed in a total area of $54.08 \mathrm{~km}^{2}$. The projected cost of the $\mathrm{si}$ blankets is $\$ 35 / \mathrm{m}^{2}$.

The primary structure for both types of solar cells is of open-truss design made of thermoplastic reinforced with graphite fiber. The basic truss elements are designed for automatic fabrication in space.

\section{E.2.2 Power Distribution System}

The prime function of the power distribution system. is to collect, regulate, and control power from the. solar-array sections; to control, condition, and transmit this power to microwave generators on the transmitting antenna; to provide for energy storage during occultations of the sun by the earth or moon, or during system maintenance; and to provide for detection and monitoring of faults and disconnecting faulty sections. 
Power from the solar array is controlled by high-voltage circuit breakers near the buses, depending on load requirements. Two sections of the array provide the required voltage $(45.5 \mathrm{kV})$ at the sliprings, using the sheet-conductor voltage drop to achieve this voltage.

Power is transferred from sections of the solar array to the microwave attenna via rotary joints using slipring/brush assemblies. Conductors from the slipring brushes are tied to DC/DC convertors through switchgear that allow isolation of a section when it is under maintenance. Conductors are then tied between voltage-suming buses through other switchgear for transmitting the required power to the DC-RF generators.

Batteries for energy storage are located on the microwave antenna structure, with a bus routed along the regular network to provide power when the solar array is not operating. About 12 MWh of electrical energy would be stored.

\section{E.2.3 Microwave Power Transmission System}

The transfer of energy from geosynchronous orbit to earth, in the present SPS concept, would be accomplished by means of microwave transmission. Power transfer is a 3-step process: (1) converting the power from DC to microwaves; (2) focusing and transmitting the microwaves to earth's surface; and (3) collecting the microwave power on earth and converting it to DC power. The overall efficiency of this system is about $63 \%$; a breakdown of the efficrencies of the subsystems is given in Fig. E.1.

The studies performed by contractors on the microwave power amplifiers (DC to RF converters) have focused primarily on investigation of the klystron (a linear beam ampiifier) and the amplitron (a crossed-field amplifier). According to these studies, $6^{\circ}$ the klystron is preferred because of better peifurmance, including much higher power per tube, higher operating voltage, lower noise levels, and much lower phase-control drive power.

The microwave transmission system assumed has a phased-array transmitting antenna $1 \mathrm{~km}$ in diameter. This antenna is composed of 7,220 subarrays with slotted waveguides, as the radiating surface and DC-RF power tubes mounted on the back. Both the primary and the secondary structure of the antenna are composed of a graphite/epoxy. material. The primary structure is an open A-frame truss, and the secondary structure is a deployable cubic truss which 
provides support for installation of the microwave subarrays. The slotted waveguides are assumed to be made of aluminum. 6

The present configuration of the ground rectenna, which receives and rectifies the power beam, has half-wave dipoles feeding Schottky barrier diodes. 6 Two-stage, low-pass filters between the dipoles and diodes suppress harmonic generation and provide impedance matching. For economic reasons, the rectenna is a series of serrated panels perpendicular to the incident beam $r$ ather than a continuous structure. RF power collected at the rectenna is converted to DC power to be used in utility power levels..through the unit processes such as RF-DC conversion, DC power interface, and DC/DC processing.

\section{E.2.4 Material Requirements}

The materials needed for the SPS program are presented in Table E.1.6 These requirements have been estimated for individual system components, such as the satellite station, ground station, and various transport vehicles.

The satellite station requirements are separated into three major segments: a 5-GW satellite system, low earth orbit (LEO) staging, construction of an orbital transfer vehicle (OTV), and construction in geosynchronous orbit (GEO). The satellite masses, which are shown in Table E. 2,6 consist of the solar array, the microwave antenna, and array/antenna interfaces. The GaAlAs option in the solar array uses a radiation concentration ratio of 2. which reduces the required blanket area and therefore the blanket mass.

The rectenna is the main part of the ground unit. It is composed of steel panels supported by steel columns in concrete footings; aluminum conductors are used for the power collection system. According to the present concept report, 6 the projected cost for the rectenna structure is over $20 \%$ of the total SPS program, even though a recent redesign of the rectenna eliminated over $75 \%$ of the aluminum from the original 1976 design. This component needs further study to bring costs down.

\section{E.2.5 Space Transportation System}

This section describes the space transportation vehicles assumed in the present study. The vehicles are distinguished by their primary payload, either cargo or personnel, and their area of operation, i.e., between earth and low earth orbit (LEO), or between LEO and geosynchronous earth orbit (GEO). 
Table E.1. Materials Requirements (Metric Tons) for SPS

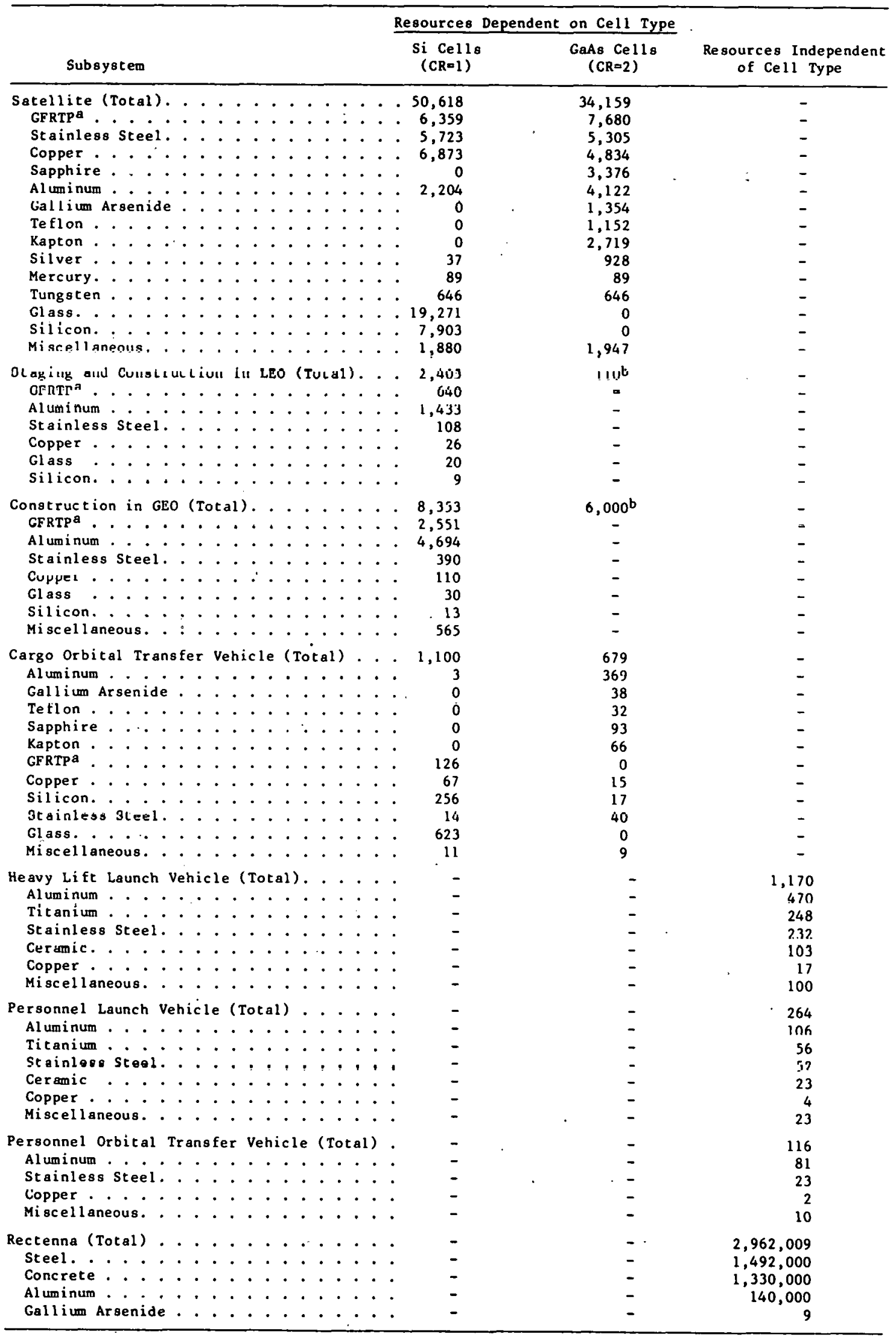

${ }^{a}$ Graphite-Fiber-Reinforced Thermoplastic.

bonly estimates of totals currently available.

Source: Ref. 6 . 
Table E.2. Masses of SPS Subsystems

\begin{tabular}{|c|c|c|c|c|}
\hline \multirow[b]{2}{*}{ Subsystem } & \multicolumn{4}{|c|}{ Mass. $10^{6} \mathrm{~kg}$} \\
\hline & $\begin{array}{l}\text { GaAlAs } \\
\mathrm{CR}=2\end{array}$ & & $\begin{array}{l}\text { Silicon } \\
\mathrm{CR}=1\end{array}$ & \\
\hline Solar Array & & 13.798 & & 27.258 \\
\hline Primary Structure & 4.172 & & 3.388 & \\
\hline Secondary Structure & 0.581 & & 0.436 & \\
\hline Solar Blankets & 6.696 & & 22.051 & \\
\hline Concentrators & 0.955 & & - & \\
\hline $\begin{array}{l}\text { Power Distribution } \\
\text { and Conditioning }\end{array}$ & 1.144 & & 1.134 & \\
\hline $\begin{array}{l}\text { In formation Management } \\
\text { and Control }\end{array}$ & 0.050 & & 0.050 & . \\
\hline $\begin{array}{l}\text { Attitude Control and } \\
\text { Stationkeeping }\end{array}$ & 0.200 & & 0.200 & \\
\hline Antenna & & 13.382 & & 13.382 \\
\hline Primary Structure & 0.250 & & 0.250 & \\
\hline Secondary Structure & 0.786 & & 0.786 & \\
\hline Transmitter Subarrays & 7.178 & & 7.178 & \\
\hline $\begin{array}{l}\text { Power Distribution and } \\
\text { Conditioning }\end{array}$ & 2.189 & & 2.189 & \\
\hline 'l'hermal Control & 2.222 & & 2.222 & \\
\hline $\begin{array}{l}\text { Information Management } \\
\text { and Control }\end{array}$ & 0.630 & & 0.630 & \\
\hline Attitude Control & 0.128 & & 0.128 & \\
\hline Array Antenna Interfaces ${ }^{a}$ & & 0.147 & & 0.147 \\
\hline Primary Structure & 0.094 & & 0.094 & \\
\hline Secondary Structure & 0.003 & & 0.003 & \\
\hline Mechanisms & 0.033 & & 0.033 & \\
\hline Power Distribution & 0.017 & & 0.017 & \\
\hline Subtotal & & 27.327 & & 40.787 \\
\hline Cont ingency $(25 \%)$ & & 6.832 & & 10.197 \\
\hline Total & & 34.159 & & 50.984 \\
\hline
\end{tabular}

${ }^{a}$ Rotary joint, slip rings, antenna yoke.

Source: Ref. 6. 
Heavy Lift Launch Vehicle (HLLV). The reference HLLV is a two-stage (booster and orbiter), vertical take-off, horizontal landing, fully reusable, winged launch vehicle. The vehicle uses 16 liquid methane/liquid oxygen engines on the booster (first stage) and 14 standard Space Shuttle Main Engines (SSME) on the orbiter (second stage). Cargo is transported from the earth's surface to LEO by the HLLV.

Personnel Launch Vehicle (PLV). The PLV provides for the transportation of personnel and priority cargo between earth and LEO. The reference vehicle is derived from the current space. shuttle system. It uses methanefueled, winged flyback boosters with smaller external tanks than those on the existing shuttle. The booster employs 4 methane/oxygen engines similar to those on the HLLV booster.

Cargo Orbital Transfer Vehicle (COTV). The function of the coTV is to deliver SPS cargo to GEO from the LEO staging area. The basic concept involves constructing. a fleet of reusable round-trip vehicles powered by solar-electric arrays in LEO. The vehicles would use ion-bombardment thrusters, with cryogenic argon as the propellant.

Personnel Orbital Transfer Vehicle (POTV). The functions of the POTV are to deliver personnel and priority cargo from LEO to GEO and to return personnel from GEO and LEO at 90-day intervals. The reference vehicle has two stages and is fueled with oxygen and hydrogen; it could make the trip in about ine day.

\section{E. 3 ENERGY BALANCE PARAMETERS}

Figure E.2. shows the primary energy flow for the GaAlAs and $\mathrm{Si}$ cell options, with the satellite designed to provide $5 \mathrm{GW}$ of DC power to the utility busbar and overali efficiencies of $6.9 \%$ and $7.0 \%$, respectively. The system, based on a 5-GWe unit operating at a plant factor of $92 \%$, generates $145.18 \times 10^{15} \mathrm{~J} / \mathrm{yr}\left(40.32 \times 10^{9} \mathrm{kWh} / \mathrm{yr}\right)$. It is necessary to size the solar arrays to intercept approximately $2,100 \times 1015 \mathrm{~J}$ of solar energy as indicated in Fig. E.2.

Table E:3 summarizes the energy balance parameters. Table E.4 summarizes the system materials requirements, and Table E.5 shows the conversion 

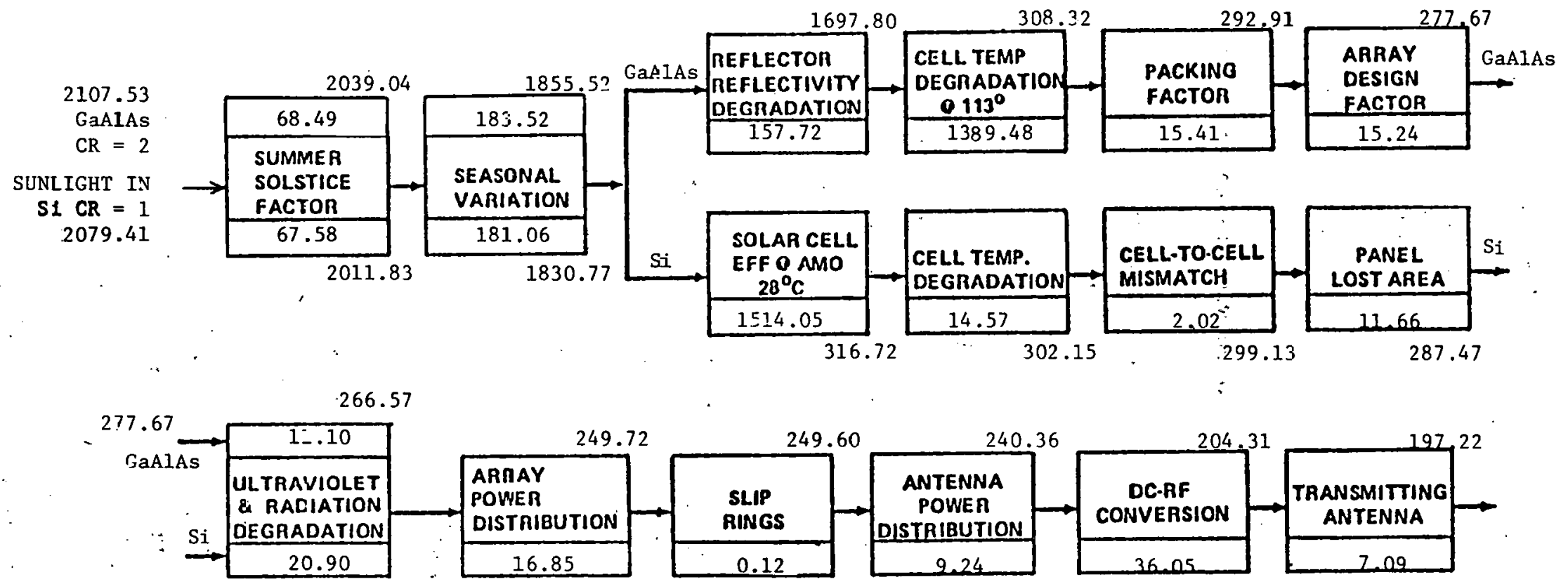

287.47266 .57

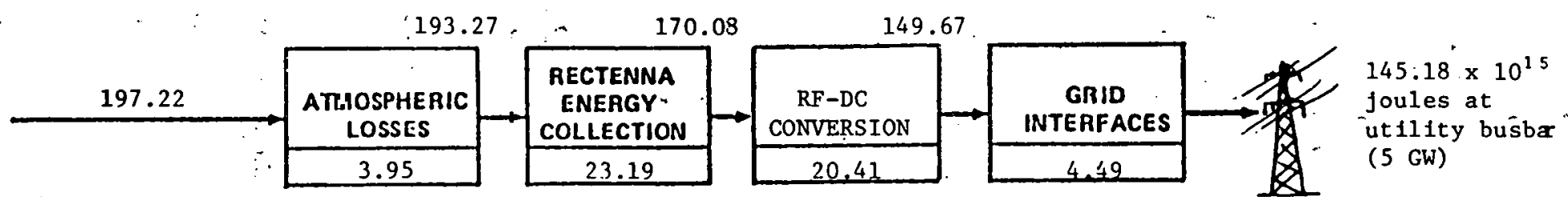

Fig. E.2. Primary Energy Flow Diagram for SPS $\left(10^{15} \mathrm{~J} / \mathrm{yr}\right)$ 
Table E.3. Energy Balance Parameters for SPS

\begin{tabular}{|c|c|c|c|c|c|c|c|}
\hline \multirow[b]{2}{*}{$\begin{array}{l}\text { System } \\
\text { Element }\end{array}$} & \multicolumn{3}{|c|}{ Annual Primary Input } & \multirow{2}{*}{$\begin{array}{l}\text { Total Capital } \\
\text { Input: Energy } \\
\left(10^{15} \mathrm{~J}\right)\end{array}$} & \multirow{2}{*}{$\begin{array}{l}\text { Annual Operating } \\
\text { Input: } \text { Energy } \\
\left(10^{15} \mathrm{~J}\right)\end{array}$} & \multicolumn{2}{|c|}{$\begin{array}{l}\text { Annual Output, } \\
\text { Electricity }\end{array}$} \\
\hline & Type & $\begin{array}{l}\text { Quantity } \\
\left(10^{9} \text { : } \text {.Whe }\right)\end{array}$ & $\begin{array}{l}\text { Energya } \\
\left(1015^{\mathrm{a}}\right)\end{array}$ & & & $\begin{array}{l}\text { Quantity } \\
\left(10^{9} \text { kWhe }\right)\end{array}$ & $\begin{array}{l}\text { Energya } \\
\left(10^{1} 5^{\mathrm{J}}\right)\end{array}$ \\
\hline \multicolumn{8}{|l|}{$\begin{array}{l}\text { Collection } \\
\text { System }\end{array}$} \\
\hline $\begin{array}{l}\mathrm{Si} \\
\text { GaAlAs }\end{array}$ & $\begin{array}{l}\text { Solar } \\
\text { Radiation } \\
\text { Solar } \\
\text { Radiation }\end{array}$ & - & 2079.41 & $\begin{array}{l}-c \\
-c\end{array}$ & - & $\begin{array}{l}74.05 \\
74.05\end{array}$ & $\begin{array}{l}266.57 \\
266.57\end{array}$ \\
\hline $\begin{array}{l}\text { Power } \\
\text { Distribution }\end{array}$ & Electricity & 74.105 & 256.57 & $-c$ & - & 66.77 & 240.36 \\
\hline $\begin{array}{l}\text { Microwave } \\
\text { Transmission }\end{array}$ & Electricity & 66.77 & 240.36 & $-c$ & - & $40.33^{d}$ & $145.18^{d}$ \\
\hline \multicolumn{8}{|l|}{ Entire System } \\
\hline $\begin{array}{l}\text { S1 } \\
\text { GaAlAs }\end{array}$ & - & $\begin{array}{l}- \\
-\end{array}$ & $\overline{-}$ & $\begin{array}{l}871.246^{c} \\
186.403^{c}\end{array}$ & $\begin{array}{l}8.712^{b} \\
1.86 T^{b}\end{array}$ & $\begin{array}{l}- \\
-\end{array}$ & - \\
\hline
\end{tabular}

${ }^{a}$ Energy input and output is computed as the heat content of fuels and materials or joule equivalent of electricity generated.

bAnnual operating input is assumed to be $30 \%$ of capital input, amortized over a 30 -yr system 11 fetime. CDetails are shown in Tables E.4 and E. 5 .

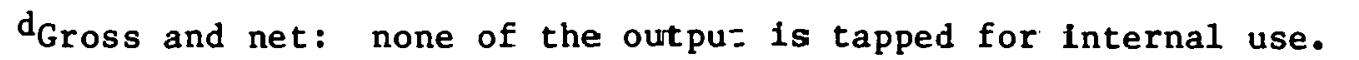


Table E.4. Total Masses of All SPS Program Components

\begin{tabular}{|c|c|c|c|c|}
\hline \multirow{3}{*}{$\begin{array}{c}\text { Satellite } \\
\text { Program Materials }\end{array}$} & \multicolumn{4}{|c|}{ Mass, Metric Tons } \\
\hline & \multicolumn{2}{|c|}{ Through First 5-GW SPS ${ }^{a}$} & \multicolumn{2}{|c|}{ Two 5-GW Satellites/Year } \\
\hline & $\mathrm{Si}(\mathrm{CR}=1)$ & GaAlAs $(C R=2)$ & $\mathrm{Si}\left(\mathrm{CR} \frac{\mathrm{i}}{\mathbf{T}} 1\right)$ & GaAlAs $(C R=2)$ \\
\hline GFRTP & 12,447 & 7,680 & 12,716 & 15,360 \\
\hline Stainless Steel & 7,621 & 6,511 & 11,446 & 10,610 \\
\hline Glass & 33,650 & 0 & 38,542 & 0 \\
\hline Silicon & 13,813 & 0 & 15,806 & 0 \\
\hline Copper & $8,6.30$ & 5,030 & 13,746 & 9,668 \\
\hline Aluminum & 150,654 & 149,227 & 284,408 & 288,244 \\
\hline Silver & 37 & 928 & 74 & 1,856 \\
\hline Mo1ybdenum & 2 & 0 & 4 & 0 \\
\hline Mercury & 89 & 89 & 178 & 178 \\
\hline Tungsten & 646 & 646 & 1,292 & 1,292 \\
\hline Steel & $1,492,000$ & $1,492,000$ & $2,984,000$ & $2,984,000$ \\
\hline Concrete & $1,330,000$ & $1,330,000$ & $2,660,000$ & $2,660,000$ \\
\hline Gallium Arsenide & 7 & 1,696 & 14 & 2,708 \\
\hline Titanium & 1,104 & 856 & 248 & 124 \\
\hline Ceramics & 458 & 355 & 103 & 52 \\
\hline Misc. \& Organics & 3,084 & $8.66 .3^{b}$ & 3,700 & 3,984 \\
\hline Argon ${ }^{C}$ & 20,559 & 4,876 & 18,690 & 4,664 \\
\hline $\mathrm{H}_{2}{ }^{\mathrm{c}}$ & 107,406 & 61,227 & 128,547 & 80,920 \\
\hline $\mathrm{O}_{2}{ }^{\mathrm{c}}$ & $2,268,033$ & $1,164,528$ & $2,728,506$ & $1,680,710$ \\
\hline $\mathrm{CH}_{4}{ }^{\mathrm{C}}$ & 540,572 & 265,539 & 651,599 & $\quad 379,930$ \\
\hline Sapphire & 0 & 4,213 & 0 & 6,752 \\
\hline Teflon & 0 & 1,441 & 0 & 2,306 \\
\hline Kapton. & 0 & 3,313 & 0 & 5,438 \\
\hline
\end{tabular}

aThe first satellitc includes not unly transportation and rectenna, but also the orbital staging and construction bases, plus the construction of the cargo orbital. vehicles.

${ }^{b}$ Also included is total mass estimates for LEO and GEO construction bases and OTV construction.

CPropellants of space transport used for the construction.

Source: Refs. 1 and 6. 
Table E.5. Total Capital Inputs, for, SPS

\begin{tabular}{|c|c|c|c|c|c|c|c|c|c|c|c|c|c|c|c|c|}
\hline \multirow[b]{3}{*}{ Material } & \multicolumn{4}{|c|}{ Satellite ${ }^{a}$} & \multirow{2}{*}{\multicolumn{2}{|c|}{$\begin{array}{c}\text { LEO/GEO } \\
\text { ConstruEtion }\end{array}$}} & \multicolumn{4}{|c|}{ Flight Vehicles } & & & \multicolumn{4}{|c|}{ Other } \\
\hline & \multicolumn{2}{|c|}{ Si System } & \multicolumn{2}{|c|}{ GaAlAs Sys $=\geq m$} & & & \multicolumn{2}{|c|}{ Si System } & \multicolumn{2}{|c|}{ GaAlAs System } & \multicolumn{2}{|c|}{ Rectenna (both systems) } & \multicolumn{2}{|c|}{ Si System } & \multicolumn{2}{|c|}{ GaAlAs System } \\
\hline & $\mathrm{t}$ & $10^{15} \mathrm{~J}$ & $t$ & $1.1^{15} \mathrm{~J}$ & $=$ & $10^{15} \mathrm{~J}$ & c & $10.5 \mathrm{~J}$ & $t$ & $10^{15} \mathrm{I}$ & $\dot{i}$ & $1015 \mathrm{~J}$ & $t^{\circ}$ & $10^{15} \mathrm{~J}$ & $t$ & $10^{15} \mathrm{~J}$ \\
\hline GFRTPC & 6,359 & 4.100 & $\therefore, 680$ & 4.750 & 3,191 & 2.063 & 126 & 0.080 & -- & -- & -- & -- & 2,771 & 1.785 & -- & -- \\
\hline Stainless Steel & 5,723 & 0.550 & 5,305 & 0.510 & $\$ 98$ & 0.043 & 321 & 0.031 & 347 & 0.033 & -- & -- & 1,079 & 0.103 & 859 & 0.082 \\
\hline Glass & 19,271 & 3.399 & -- & -- & 50 & 0.009 & 623 & 0.110 & -- & -- & -- & - & 13,706 & 2.418 & -- & -- \\
\hline Silicon & 7,903 & $395.466^{d}$ & -- & -- & 22 & $1.10 !^{d}$ & 256 & $12.810^{d}$ & -- & -- & -- & - & 5,632 & $281.825 d$ & -- & -- \\
\hline Copper & 6,873 & $1.75 i$ & $4,83 c$ & 1.236 & 136 & 0.035 & 90 & 0.023 & 38 & 0.010 & -- & $-{ }^{\prime}$ & 1,531 & 0.391 & 158 & 0.040 \\
\hline Alumi num & 2,204 & 1.154 & $4,12 i$ & 2.159 & 6,127 & 3.200 & 660 & 0.346 & 1,026 & 0.537 & 140,000 & 73.332 & 1,663 & 0.871 & 4,079 & 2.137 \\
\hline Silver & 37 & 0.010 & 928 & 0.254 & -- & -- & -- & -- & -- & - & -- & - & -- & -- & -- & $\therefore$ \\
\hline Molybdenum & -- & -- & -- & -- & -- & - & -- & -- & -- & -- & -- & - & 2 & 0.001 & -- & -- \\
\hline Mercury & 89 & 0.016 & 89 & C.016 & -- & - & -- & -- & -- & -- & -- & - & -- & -- & -- &.-- \\
\hline Tungs ten & 646 & 0.116 & 646 & C.116 & -- & -- & -- & -- & -- & -- & -- & -- & -- & - & -- & -- \\
\hline Steel & -- & -- & -- & -- & -- & -- & -- & -- & -- & -- & $1,492,000$ & $4 C .433$ & -- & -- & -- & -- \\
\hline Concrete & -- & -- & -- & -- & -- & - & -- & -- & -- & -- & $1,330,000$ & c. 788 & -- & -- & -- & -- \\
\hline Gallium Arsenide & -- & -- & 1,354 & $2 \epsilon 810$ & -- & -- & -- & -- & 38 & 0.752 & -- & -- & -- & -- & 295 & 5.841 \\
\hline Titanium & - & -- & -- & -- & -- & -- & 304 & C.055 & 304 & 0.055 & -- & -- & 800 & 0.144 & 552 & 0.099 \\
\hline Ceramics & -- & -- & -- & -- & -- & -- & 126 & 0.023 & 126 & 0.023 & -- & -- & 332 & 0.060 & 229 & 0.041 \\
\hline Misc. SO Organics & 1,880 & 0.338 & $\therefore, 940$ &. .350 & 565 & 0.102 & 144 & 0.026 & 142 & 0.026 & -- & -- & 495 & 0.089 & 6,574 & 1.183 \\
\hline Argon & -- & -- & -- & -- & -- & -- & -- & -- & -- & -- & -- & - & 20,559 & 0.529 & 4,876 & 0.126 \\
\hline Hydrogen & - & -- & -- & -- & -- & -- & -- & -- & -- & -- & -- & -- & 107,406 & 2.533 & 61,227 & i. 444 \\
\hline Oxygen & -- & -- & -- & -- & -- & -- & -- & -- & -- & -- & -- & -- & $2,268,033$ & 19.596 & $1,164,528$ & 10.062 \\
\hline $\mathrm{CH}_{4}$ & - & -- & -- & -- & -- & -- & -- & - & -- & -- & -- & -- & 540,572 & 15.374 & 265,539 & 7.552 \\
\hline Sapphire & -- & - & 3,376 & 2.462 & -- & - & -- & -- & 93 & 0.013 & -- & -- & -- & -- & 744 & 0.102 \\
\hline Teflon & -- & -- & $1,1 \leq 2$ & 3.158 & -- & - & -- & -- & 32 & 0.004 & -- & -- & -- & -- & 257. & 0.035 \\
\hline Rapt on & -- & -- & 2,719 & 3.372 & -- & - & -- & -- & 66 & 0.009 & -- & - & -- & -- & 528 & 0.072 \\
\hline TOTAL & - & 406.906 & - & 37.393 & -- & 6.504 & -- & 13.504 & - & 1.462 & -- & 115.553 & -- & 325,719 & $-\cdots$ & 28.816 \\
\hline
\end{tabular}

'Tne LEO/GEO construction requirements af the GaAlos satellite are not completely defined.

CGlass fiber reinforced themoplastic.

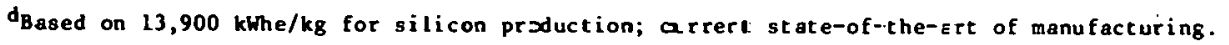


of these requirements into capital energy investment using the intensity factors from Appendix A.

\section{E.4 IDENTIFICATION OF SENSITIVE DATA}

Because of the uncertainties and limitations of data, it is extremely important, but also very difficult at this time, to perform a sensitivity analysis of the SPS. . The impact of silicon energy requirements and the energy intensity of other materials have already been discussed in Sect. 4. 
1. Satellite Power System Baseline Review by The Marshall Space Flight Center and the Lyndon B. Johnson Space Center, NASA, Washington, D.C. (July 13, 1978).

2. Satellite Power System Concept Evaluation Program (July 1977 - August 1980) -- A Recommended Preliminary. Baseline Concept, NASA, Lyndon B. Johnson Space Center, Huuston (Jan. 25, 1978).

3. Preliminary Baseline SPS Concept Recommendations to DOE/NASA by the Marshall Space Flight Center, NASA, Washington, D.C. (Jan. 24, 1978).

4. Satellite Power System Concept Definition Study First Quarterly Review, prepared for Marshall Space Flight Center by Rockwell International Space Division (June 23, 1977).

5. Herendeen, R. A., Energy Analysis of Two Technologies: Gasohol and Solar Satellite Power Station, Energy Research Group, University of Illinois, Urbana, I11. (1978).

6. Satellite Power System Concept Development and Evaluation Program Reference System Report, Report No. DOE/ER-0023, U.S. Department of Energy (Oct. 1978).

7. Glaser, P.E., Power from the Sun: Its Future, Science 162, pp. 857-886 (1968).

8. Pilati; D., Energy Analy6is of Eleclricity Supply and Energy conservation Options, Energy 2, pp. 1-7 (1977).

9. Herendeen, R., T. Kary, and J. Rebitzer, Energy Analysis of Solar Satellite Power Station, printed in Hearing Reçord,. Committee on Science and lechnology, U.S. House of Representatives, Bill on H.R. 11725, p. 429-431, (Apr. 12-14, 1978).

10. Herendeen, R., and C. Bullard, Energy Cost of Consumer Goods 1963/67, CAC Doc. 140, Center for Advanced Computation, University of Illinois, Urbana, İil. (November 1974). 


\section{Unitı itates}

Department of Energy

Washington, DC 20585

Postage and Fees Paid

U.S. Department of Energ

DOE-350

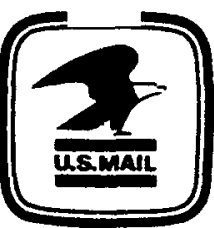

Official Business

Penalty for Private Use, $\$ 300$

FIRST CLASS MAIL 